\title{
LÍVIA CASTELANI
}

\section{Uso de bacteriocina e nanofragmentos de lípides catiônicos contra Staphylococcus spp. resistentes isolados de mastite bovina}

Tese apresentada ao Programa de Pós-Graduação em Microbiologia do Instituto de Ciências Biomédicas da Universidade de São Paulo, para obtenção do título de Doutor em Ciências.

São Paulo

2016 


\section{Lívia Castelani}

Uso de bacteriocina e nanofragmentos de lípides catiônicos contra Staphylococcus spp. resistentes isolados de mastite bovina

Tese apresentada ao Programa de PósGraduação em Microbiologia do Instituto de Ciências Biomédicas da Universidade de São Paulo, para obtenção do título de Doutor em Ciências.

Área de concentração: Microbiologia

Orientador: Prof. Dr. Nilton Lincopan

Versão original

\section{São Paulo}

2016 


\section{DADOS DE CATALOGAÇÃO NA PUBLICAÇÃO (CIP)}

Serviço de Biblioteca e Informação Biomédica do Instituto de Ciências Biomédicas da Universidade de São Paulo

reprodução não autorizada pelo autor

\section{Castelani, Livia.}

Uso de bacteriocina e nanofragmentos de lípides catiônicos contra Staphylococcus spp. resistentes isolados de mastite bovina. / Livia Castelani. -- São Paulo, 2016.

Orientador: Prof. Dr. Nilton Erbet Lincopan Huenuman.

Tese (Doutorado) - Universidade de São Paulo. Instituto de Ciências Biomédicas. Departamento de Microbiologia. Área de concentração: Microbiologia. Linha de pesquisa: Resistência bacteriana e alternativas de tratamento.

Versão do título para o inglês: Use of bacteriocin and cationic lipid nano-fragments against resistant Staphylococcus spp. isolated from bovine mastitis.

$\begin{array}{lll}\text { 1. Brometo de dioctadecildimetilamônio 2. Mastite bovina } & 3 \text {. Nisina }\end{array}$ 4. Staphylococcus aureus 5. Staphylococcus coagulase negativa I. Huenuman, Nilton Erbet Lincopan II. Universidade de São Paulo. Instituto de Ciências Biomédicas. Programa de Pós-Graduação em Microbiologia III. Título. 


\begin{abstract}
Candidato(a): $\quad$ Lívia Castelani.
Título da Tese: $\quad$ Uso de bacteriocina e nanofragmentos de lípides catiônicos contra Staphylococcus spp. resistentes isolados de mastite bovina.
\end{abstract}

Orientador(a): $\quad$ Prof. Dr. Nilton Erbet Lincopan Huenuman.

A Comissão Julgadora dos trabalhos de Defesa da Tese de Doutorado, em sessão pública realizada a ...................., considerou
( ) Aprovado(a)
( ) Reprovado(a)

\begin{tabular}{|c|c|}
\hline Examinador(a): & $\begin{array}{l}\text { Assinatura: } \\
\text { Nome: ........ } \\
\text { Instituição: . }\end{array}$ \\
\hline Examinador(a): & $\begin{array}{l}\text { Assinatura: } \\
\text { Nome: ......... } \\
\text { Instituição: . }\end{array}$ \\
\hline Examinador(a): & $\begin{array}{l}\text { Assinatura: } \\
\text { Nome: ........ } \\
\text { Instituição: }\end{array}$ \\
\hline Examinador(a): & $\begin{array}{l}\text { Assinatura: } \\
\text { Nome: ........ } \\
\text { Instituição: }\end{array}$ \\
\hline Presidente: & $\begin{array}{l}\text { Assinatura: } \\
\text { Nome: ........ } \\
\text { Instituição: }\end{array}$ \\
\hline
\end{tabular}




\section{do \\ ICBUSP}

Cidade Universitária "Armando de Salles Oliveira", Butantã, São Paulo, SP · Av. Professor Lineu Prestes, 2415 - ICB III - 05508000 Comissão de Ética em Pesquisa - Telefone (11) 3091-7733 - e-mail: cep@icb.usp.br

Decl. CEPSH.001.2016

\section{DECLARAÇÃo}

Em adendo ao Certificado de Isenção CEP-ICB no 650/14, de 26/02/2014, e por solicitação do Prof. Dr. Nilton Lincopan, do Departamento de Microbiologia, informo que o título do projeto de doutorado da aluna Lívia Castelani foi alterado para "Uso de bacteriocina e nanofragmentos de lípides catiônicos frente à Staphylococcus spp. resistentes isolados de mastite bovina " sem modificações de seu conteúdo, conforme sugerido pela banca de qualificação.

São Paulo, 09 de março de 2016.

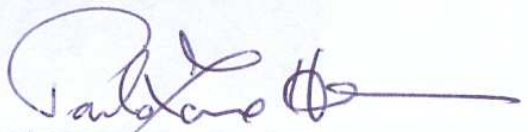

Prof. Dr. PAOLO M. A. ZANOTTo

Coordenador da CEPSH-ICB/USP

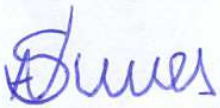

Prof. Dr. Anderson de Sá Nunes

Coordenador da CEUA-ICB/USP 
"Dedico a todos aqueles, que de coração, acreditaram na minha vitória!" 


\section{AGRADECIMENTOS}

À Deus, acima de tudo! Pelo dom da vida! Por me dar forças e saúde para conquistar meus ideais. E nessa jornada louca, me presentear com pessoas especiais, que me auxiliam e alegram minha caminhada. "Eu entrego, eu confio, eu aceito, eu agradeço", sempre!

À minha família, minha base, meu alicerce! Aos meus pais, Nelson e Judite, que me ensinaram a lutar pela vida, sempre com amor e dedicação. Às minhas irmãs, Fabiana e Bruna e à minha amada Melissa, meu raio de sol!

Ao Marcos Gasqui, pelo amor, pelos momentos felizes e de descontração que compartilhamos!

À minha amiga e incentivadora, Dra. Juliana R. P. Arcaro, sobretudo pela amizade e confiança! Por estar sempre ao meu lado, por acreditar no meu potencial e me ajudar nos momentos de crise e não me deixar desistir. Por compartilhar conhecimentos e experiências.

Aos funcionários da Fazenda Palmeiras, pela convivência e por aturar minhas loucuras. Em especial à Tereza Lídia, pela amizade, por sempre acreditar e torcer por minha vitória, pelos cafés, pelo conselho amigo. Às meninas do Laboratório de Qualidade do Leite, Jéssica e Andressa, pela ajuda na bancada, pelas risadas, pela amizade e confiança. À Thayna, pela sincera amizade, pelas sextas-feiras que tanto me fazem falta. E a Dra. Claudia R. Pozzi, pelos conselhos.

Ao Clube do Coração Peludo, pela amizade e momentos de descontração!

Aos companheiros do Lab. 240, Jacinta, Luana, Luciana, Luciane, Miriam, Rodrigo. Em especial a Quézia, que tanto me ajudou e me ouviu, exemplo de mulher! E a Tatiane, por dividir comigo o apê, as dificuldades, os risos, as lágrimas, as cervejas, os petiscos...

Ao meu orientador, Prof. Dr. Nilton Lincopan, pela oportunidade!

Ao Prof. Dr. Jorge Sampaio, pelas análises de MALDI-TOF.

Ao Prof. Dr. Mauro J. C. Veliz e ao Ismael Sauter, pela ajuda com a microscopia de fluorescência.

À CAPES, pela bolsa concedida e à FAPESP, pelo auxílio financeiro, Projeto $\mathrm{n}^{\circ}$ 2013/15504-4.

À todos, que de alguma forma fizeram parte de mais essa etapa da minha vida, meus sinceros agradecimentos! 
Disse a flor ao pequeno príncipe:

- "É preciso que eu suporte duas ou três larvas se quiser conhecer as borboletas." (Antoine de Saint-Exupéry)

“They tried to bury us. They didn't know we were seeds." (Provérbio Mexicano) 


\section{RESUMO}

CASTELANI, L. Uso de bacteriocina e nanofragmentos de lípides catiônicos contra Staphylococcus spp. resistentes isolados de mastite bovina. 2016. $71 \mathrm{f}$. Tese (Doutorado em Microbiologia) - Instituto de Ciências Biomédicas, Universidade de São Paulo, São Paulo, Brasil, 2016.

Staphylococcus spp. são reportados com um dos principais agentes etiológicos da mastite bovina, onde a diversidade de fatores de virulência e elevada resistência antimicrobiana contribuem para o prognóstico desfavorável da infecção. Com relação aos tratamentos, muitos dos antimicrobianos comercialmente disponíveis para a mastite bovina geram resíduos que alteram a qualidade e segurança alimentar do leite e seus derivados. Neste cenário, a busca por novas alternativas de controle e tratamento tornam-se imprescindíveis. Bacteriocinas e nanopartículas têm emergido como alternativas promissoras para futuros desenvolvimentos de agentes antimicrobianos. O objetivo deste estudo foi avaliar in vitro a atividade antibacteriana da bacteriocina nisina (NS), de nanofragmentos do lípide catiônico brometo de dioctadecildimetilamônio (DDA) e do complexo NS/DDA contra cepas de Staphylococcus spp. resistentes isoladas de mastite de novilhas primíparas e vacas em lactação, de rebanhos leiteiros de diferentes propriedades experimentais e comerciais. Para todos os isolados, o perfil de sensibilidade antibacteriana foi determinado por difusão de disco e a atividade in vitro da nisina e DDA foi avaliada pela determinação da concentração bactericida mínima (CBM). O efeito sinérgico do complexo NS/DDA foi determinado através do método de checkerboard e estudo de time-kill. A viabilidade celular foi adicionalmente avaliada por microscopia de fluorescência. O tamanho $(\mathrm{nm})$, polidispersibilidade e potencial zeta $(\zeta)$ dos complexos NS/DDA e a sua interação com uma cepa representativa de $S$. aureus foram determinados por espalhamento de luz dinâmico (DLS). A $\mathrm{CBM}_{50}$ da nisina foi de $50 \mu \mathrm{g} / \mathrm{mL}$ e a $\mathrm{CBM}_{50}$ do DDA foi de $4 \mu \mathrm{g} / \mathrm{mL}$, enquanto que a $\mathrm{CBM}_{50}$ do complexo NS/DDA foi $3 / 2$ $\mu \mathrm{g} / \mathrm{mL}$ (efeito parcialmente sinérgico, $\Sigma \mathrm{FBC}$ entre $>0,5-\leq 1,0$ ). O estudo de time-kill revelou uma redução de $\geq 3 \log _{10} \mathrm{UFC} / \mathrm{mL}$ após uma hora de interação entre o complexo NS/DDA e a bactéria. De fato, a microscopia de fluorescência confirmou uma perda da viabilidade após 6 horas de interação. A interação NS/DDA resultou em um complexo catiônico $(+8,84 \mathrm{mV})$ na escala nanométrica $(148,5 \mathrm{~nm})$, o que contribui para a adesão à superfície bacteriana negativa $(-27,32 \mathrm{mV})$, favorecendo a ação bactericida do complexo. $\mathrm{O}$ complexo NS/DDA se mostrou como uma alternativa promissora para o controle de Staphylococcus spp. resistentes isolados de mastite bovina.

Palavras-chave: Brometo de dioctadecildimetilamônio. Mastite bovina. Nisina. Staphylococcus aureus. Staphylococcus coagulase negativa. 


\begin{abstract}
CASTELANI, L. Use of bacteriocin and cationic lipid nano-fragments against resistant Staphylococcus spp. isolated from bovine mastitis. 2016. 71 p. Ph.D. Thesis (Microbiology) - Instituto de Ciências Biomédicas, Universidade de São Paulo, São Paulo, Brasil, 2016.

Staphylococcus spp. are reported as a major etiological agent of bovine mastitis, where the diversity of virulence factors and high antimicrobial resistance profiles contribute to the poor prognosis of the infection. With regard to treatments, many of the commercially available antimicrobials for bovine mastitis generate waste that alters the food quality and safety of milk and dairy products. In this scenario, the search for new alternatives for control and treatment become essential. Bacteriocins and nanoparticles have emerged as promising alternatives for future development of antimicrobial agents. The aim of this study was to evaluate the "in vitro" antibacterial activity of the bacteriocin nisin (NS), cationic lipid nanofragments of dioctadecyldimethylammonium bromide (DDA) and NS/DDA complex against drug-resistant Staphylococcus spp. strains isolated from mastitis in primiparous heifers and lactating dairy cows in herds from both experimental and commercial properties. For all isolates, the antibacterial susceptibility profile was determined by disk-diffusion method and the "in vitro" activity of nisin and DDA was evaluated by determining the minimum bactericidal concentration (MBC). Synergistic effect of NS/DDA complex was determined by time-kill and checkerboard methods. Cell viability was further evaluated by fluorescence microscopy. The size $(\mathrm{nm})$, polydispersity and zeta potential $(\zeta)$ of NS/DDA complex, as well as, their interaction with a representative strain of $S$. aureus were determined by dynamic light scattering (DLS). For nisin and DDA the $\mathrm{MBC}_{50}$ was 50 and $4 \mu \mathrm{g} / \mathrm{mL}$, respectively, whereas $\mathrm{MBC}_{50}$ of NS/DDA was $3 / 2 \mu \mathrm{g} / \mathrm{mL}$ (partially synergistic effect, $\Sigma \mathrm{FBC}$ from $>0.5$ to $\leq 1.0$ ). Time-kill studies with NS/DDA revealed $\geq 3 \log _{10} \mathrm{CFU} / \mathrm{mL}$ at an hour interaction. In fact, fluorescence microscopy confirmed loss viability after six hours interaction. NS/DDA assemblies resulted in cationic complexes $(+8.84 \mathrm{mV})$ at nanoscale $(148.5 \mathrm{~nm})$, which contributes for the interaction with the negatively charged bacterial surface $(-27.32 \mathrm{mV})$, favoring the bactericidal action of the NS/DDA complex. The NS/DDA complex has shown to be a promising alternative for the control of drug-resistant Staphylococcus spp. strains isolated from bovine mastitis.
\end{abstract}

Keywords: Dioctadecyldimethylammonium bromide. Bovine mastitis. Nisin. Staphylococcus aureus. Coagulase-negative Staphylococcus. 


\section{LISTA DE ABREVIATURAS, SIGLAS E SÍMBOLOS}

\begin{tabular}{|c|c|}
\hline$\%$ & Percentagem \\
\hline$<$ & Menor \\
\hline$>$ & Maior \\
\hline$\leq$ & Menor ou igual \\
\hline$\geq$ & Maior ou igual \\
\hline (B) & Marca registrada \\
\hline$\circ$ & Graus \\
\hline${ }^{\circ} \mathbf{C}$ & Graus Celsius \\
\hline$\mu \mathrm{g}$ & Microgramas \\
\hline $\boldsymbol{\mu} \mathbf{L}$ & Microlitros \\
\hline$\mu \mathrm{m}$ & Micrometros \\
\hline $\boldsymbol{\mu} \mathbf{M}$ & Micromolar \\
\hline $\mathbf{A}$ & Antagonismo \\
\hline ATCC & American Type Culture Collection \\
\hline BAL & Bactérias ácido lácticas \\
\hline blaZ & Gene que codifica a enzima beta-lactamase \\
\hline CBM & Concentração Bactericida Mínima \\
\hline CCS & Contagem de Células Somáticas \\
\hline$c f r$ & $\begin{array}{l}\text { Gene que confere fenótipo de resistência aos fenicóis, lincosamidas } \\
\text { pleuromutilinas, estreptogramina A, macrolídeos e linezolida }\end{array}$ \\
\hline CIM & Concentração Inibitória Mínima \\
\hline Cip & Ciprofloxacina \\
\hline Cli & Clindamicina \\
\hline CLSI & Clinical Laboratory Standards Institute \\
\hline CMT & California Mastitis Test \\
\hline CoNS & Staphylococcus coagulase negativa \\
\hline CoPS & Staphylococcus coagulase positiva \\
\hline DDA & Brometo de dioctadecildimetilamônio \\
\hline Dha & Didehidroalanina \\
\hline Dhb & Didehidrobutirina \\
\hline $\mathrm{DL}_{50}$ & Dose Letal $50 \%$ \\
\hline DLS & Espalhamento de luz dinâmico \\
\hline
\end{tabular}




\begin{tabular}{|c|c|}
\hline DNA & Ácido desoxirribonucleico \\
\hline $\mathbf{D P}$ & Desvio Padrão \\
\hline $\mathbf{D}_{\mathbf{z}}$ & Diâmetro médio \\
\hline EDTA & Ácido etilenodiaminotetracético \\
\hline Eno & Enrofloxacina \\
\hline $\operatorname{erm} \mathbf{A} /$ erm $\mathbf{C}$ & $\begin{array}{l}\text { (erythromycin ribosomal methylase) - genes responsáveis pela } \\
\text { metilação do RNAr 23s }\end{array}$ \\
\hline ETs & Toxinas esfoliativas \\
\hline FAO & Food and Agriculture Organization \\
\hline FBC & Fractionary Bactericidal Concentration \\
\hline FDA & Food and Drug Administration \\
\hline Ffc & Florfenicol \\
\hline g & Grama \\
\hline Gen & Gentamicina \\
\hline GRAS & Generally Recognized As Safe \\
\hline HCl & Ácido clorídrico \\
\hline Hetero-VISA & Resistência heterogênea intermediária à vancomicina em $S$. aureus \\
\hline $\mathbf{I}$ & Indiferente \\
\hline$i c a A / i c a D$ & Genes presentes no operon icaADBC que codifica proteínas envolvidas \\
\hline & na síntese do polissacarídeo constituinte do biofilme \\
\hline IDA & Ingestão Diária Aceitável \\
\hline IGP & Isotonic Glucose Phosphate \\
\hline IL-2 & Interleucina 2 \\
\hline Kan & Kanamicina \\
\hline kDa & Kilodalton \\
\hline Lzd & Linezolida \\
\hline MALDI-TOF & Matrix-assisted laser desorption ionization time-of-flight \\
\hline $\operatorname{mec} A$ & Gene envolvido no mecanismo de resistência à oxacilina \\
\hline mg & Miligramas \\
\hline MHC & Complexo de Histocompatibilidade Maior \\
\hline $\mathbf{m L}$ & Mililitro \\
\hline $\mathbf{M L S}_{\mathbf{B}}$ & $\begin{array}{l}\text { Fenótipo responsável pela resistência aos macrolídeos, lincosamidas e } \\
\text { estreptogramina do tipo B }\end{array}$ \\
\hline $\mathbf{m M}$ & Milimolar \\
\hline
\end{tabular}


MRSA

mrsA

mV

$\mathbf{N}$

Neo

nm

NS/DDA

OMS

Oxa

PBP

PCR

Pen

pH

pka

PS

PVL

RIF

RNAr

S

SEA

SEB

SEC

SED

SEE

SEs

Str

sub-MICs

Sxt

Tet

tet

$\mathbf{T}_{\mathbf{M}}$

TSST-1
S. aureus resistente à meticilina

(specific methionine sulfoxide reductase) - gene que confere fenótipo de resistência aos macrolídeos e estreptogramina B

Milivolts

Normal

Neomicina

Nanometros

Complexo NS/DDA

Organização Mundial da Saúde

Oxacilina

Protein Binding Penicilin

Reação em Cadeia da Polimerase

Penicilina $\mathrm{G}$

Potencial Hidrogeniônico

Menos logaritmo na base 10 da constante de acidez

Efeito Parcialmente Sinérgico

Leucocidina de Panton-Valentine

Rifampicina

RNA ribossômico

Efeito Sinérgico

Enterotoxinas estafilocócicas A

Enterotoxinas estafilocócicas B

Enterotoxinas estafilocócicas C

Enterotoxinas estafilocócicas D

Enterotoxinas estafilocócicas E

Enterotoxinas estafilocócicas

Estreptomicina

Concentrações sub-inibitórias

Sulfametoxazol/trimetoprim

Tetraciclina

Superfamília de genes que codifica proteínas responsáveis pela resistência a tetraciclina

Temperatura de fusão cristalina

Toxina-1 da síndrome do choque tóxico 
UFC

UI

$\Sigma$ FBC

$\zeta$
Unidade Formadora de colônias

Unidade Internacional

Somatória das Concentrações Bactericidas Fracionais

Potencial Zeta 


\section{LISTA DE ILUSTRAÇÕES}

Figura 1 - Representação esquemática da estrutura primária da nisina. Os resíduos de lantionina (Ala-S-Ala) e $\beta$-metillantionina (Abu-S-Ala) que formam os anéis de lantionina estão em vermelho; os aminoácidos desidratados Dhb (didehidrobutirina) e Dha

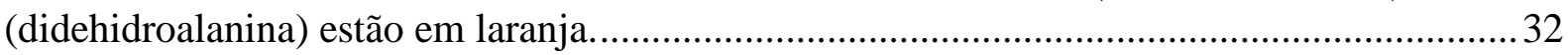

Figura 2 - Representação esquemática dos mecanismos de ação da nisina: A nisina se liga ao lípide II presente na membrana citoplasmática da bactéria, formando poros, assim como

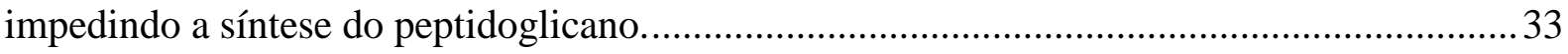

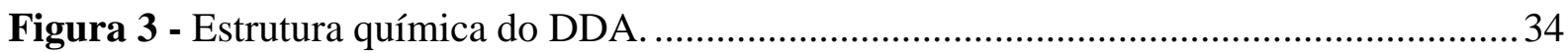

Figura 4 - Modelo de bicela carregando uma droga na borda. Drogas com carga negativas podem interagir com a cabeça polar catiônica do DDA por atração eletrostática dos compostos. Assim como, bordas hidrofóbicas das bicelas de DDA podem auxiliar essa incorporação pela hidrofobicidade de algumas drogas diretamente com a borda hidrofóbica.

Figura 5 - Representação esquemática da metodologia de checkerboard para avaliação da interação entre as moléculas de nisina e DDA. ........................................................................ 42

Figura 6 - Curva de morte em função do tempo para a cepa S. aureus MRSA N315. As bactérias foram incubadas em tampão IGP (controle); tampão IGP e concentrações da CBM da nisina, DDA e do complexo NS/DDA. Os resultados estão expressos em $\log _{10} \mathrm{UFC} / \mathrm{mL}$.

Figura 7 - Imagem de microscopia de fluorescência (x63) da cepa de S. aureus MRSA N315 tratados com complexos de NS/DDA, marcadas com SYTO 9 (verde) e iodeto de propídeo (vermelho). (A, C) - Tempo zero, com e sem filtro verde, respectivamente; (B, D) - Após seis horas de interação, com e sem filtro verde, respectivamente. Barras de escala - $5.00 \mu \mathrm{m}$....... 49

Figura 8 - Distribuição de tamanhos (diâmetro médio - $\mathrm{D}_{\mathrm{z}}$ ) em nanômetro $(\mathrm{nm})$ e potencial Zeta $(\zeta)$ em milivolts (mV). A- Cepa $S$. aureus MRSA N315; B- DDA 2 mM; C- nisina 300 $\mu \mathrm{g} / \mathrm{mL}$; D- Complexo NS/DDA 30/20 $\mu \mathrm{g} / \mathrm{mL}$. As setas indicam que as escalas estão em (A,D) $5000 \mathrm{~nm}$ e $(B, C) 500 \mathrm{~nm}$. 


\section{LISTA DE TABELAS}

Tabela 1 - Efeito citotóxico do DDA contra células de mamíferos, bactérias e levedura........36

Tabela 2 - Resultados do perfil de resistência antimicrobiana por difusão em disco, valores da CBM da nisina e DDA e dos resultados do checkerboard do complexo NS/DDA de cepas de Staphylococcus spp. isoladas de mastite bovina e de cepas $S$. aureus ATCC 46

Tabela 3 - Distribuição de tamanhos (diâmetro médio) e potencial Zeta $(\zeta)$ da nisina, DDA, da cepa de $S$. aureus MRSA N315 e diferentes associações entre eles, em tampão IGP. 


\section{SUMÁRIO}

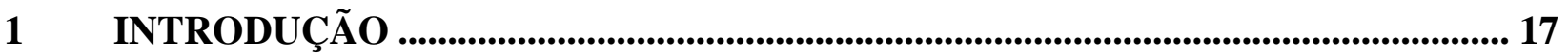

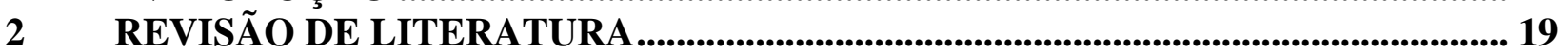

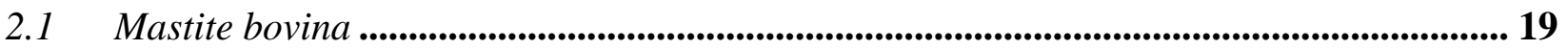

2.2 Mastite por Staphylococcus spp. ......................................................................................................... 20

2.3 Fatores de virulência de Staphylococcus spp.......................................................................... 21

$2.4 \quad$ Uso de antimicrobianos e mastite ........................................................................................................ 24

2.5 Resistência antimicrobiana em Staphylococcus spp. ....................................................... 27

2.6 Alternativas de tratamento e profilaxia para infecções produzidas por

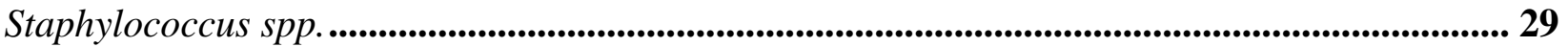

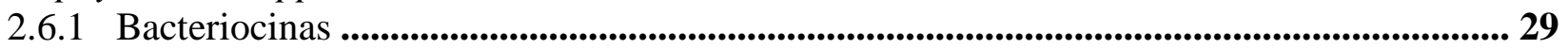

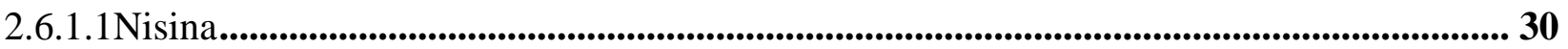

2.6.2 Brometo de dioctadecildimetilamônio (DDA) ................................................................. 33

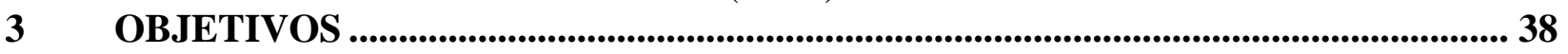

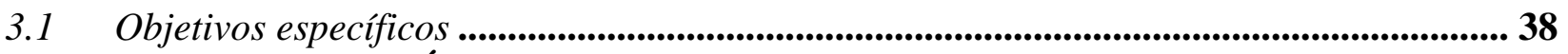

4 MATERIAL E MÉTODOS .......................................................................................... 39

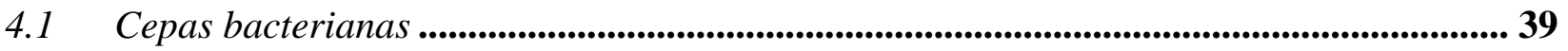

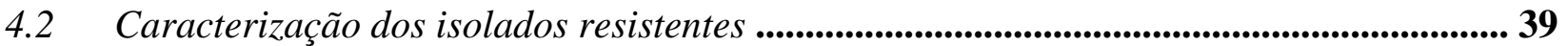

4.3 Confirmação das espécies de Staphylococcus spp ............................................................ 40

4.4 Preparação da solução estoque de nisina ............................................................................ 40

4.5 Preparação de bicelas de lipídeos sintéticos catiônicos .................................................. 40

4.6 Determinação da Concentração Bactericida Mínima (CBM) da nisina e DDA................ 40

4.7 Avaliação "in vitro" da interação entre nisina e DDA...................................................... 41

4.8 "Time-kill" (curva de morte em função do tempo) ................................................................ 43

4.9 Avaliação da viabilidade celular por microscopia de fluorescência ..................................... 43

4.10 Caracterização físico-química das partículas de nisina e DDA por "Light Scattering"

e Potencial Zeta ....................................................................................................................................................... 44

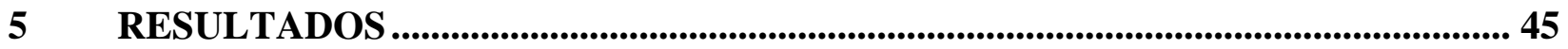

5.1 Perfil de resistência antimicrobiana e a atividade "in vitro" da nisina e DDA................. 45

$5.2 \quad$ Estudo do "Time-kill" ................................................................................................................ 48

5.3 Avaliação da viabilidade celular por microscopia de fluorescência ................................... 49

5.4 “Light Scattering” e Potencial Zeta das formulações e a sua interação com S. aureus

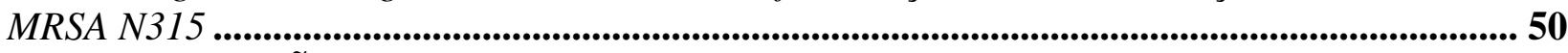

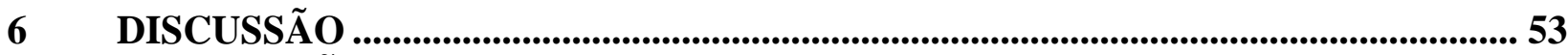

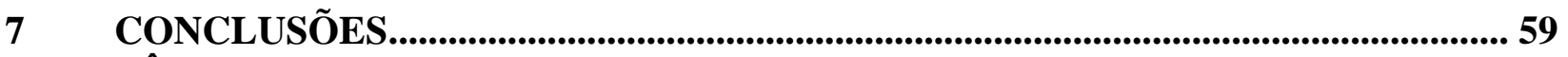

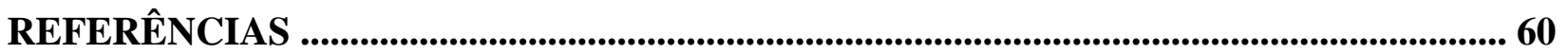




\section{INTRODUÇÃO}

A pecuária leiteira possui importância significativa na economia brasileira, devido ao relevante papel no fornecimento de alimentos, assim como na geração de empregos diretos e indiretos em toda a cadeia produtiva. Ao mesmo tempo, o Brasil é um país com grande potencial de exportação de leite no mercado mundial. Porém, o leite produzido aqui possui baixa qualidade, limitando a transformação industrial a produtos de baixo valor agregado e sem padrão de mercado (VIANA; RINALDI, 2010). Um dos principais fatores relacionados com a redução da qualidade do leite é a mastite, pois ocasiona alterações na composição do leite e diminuição na produção, além de representar riscos à saúde do consumidor pela possível presença de microrganismos patogênicos e suas toxinas, além de resíduos de antimicrobianos (SANTOS; FONSECA, 2007).

Diferentes agentes patogênicos estão envolvidos na etiologia da mastite bovina, e Staphylococcus spp. são os mais frequentemente isolados. Dentre o gênero, Staphylococcus aureus é o principal microrganismo causador de mastite contagiosa em rebanhos leiteiros de todo o mundo. Uma vaca com mastite por S. aureus apresenta queda considerável na produção, assim como na qualidade do leite (FAGUNDES; OLIVEIRA, 2004). No entanto, é frequente o isolamento de espécies de Staphylococcus coagulase negativa (CoNS) em casos de mastite bovina (PYÖRÄLA; TAPONEN, 2009). Esses microrganismos são oportunistas, pois normalmente fazem parte da microbiota da pele do teto e dessa forma, tem acesso ao interior da glândula mamária (TRINIDAD; NICKERSON; ALLEY, 1990).

Staphylococcus spp. são capazes de produzir diferentes fatores de virulência que auxiliam na sua colonização e persistência na glândula mamária, além de produzir toxinas capazes de provocar intoxicações alimentares (SANTOS; FONSECA, 2007). Ainda, esses microrganismos exibem elevada resistência aos agentes antimicrobianos usualmente empregados no controle e tratamento das mastites (LUTHJE; SCHWARZ, 2006), dificultando o tratamento das infecções, e consequentemente, aumentando as despesas aos produtores de leite (MATHEW; CISSELL; LIAMTHONH, 2007).

Sendo assim, há uma grande necessidade de se desenvolver novas terapias alternativas eficazes de controle e tratamento da mastite bovina, que visem um produto mais seguro e de melhor qualidade. Uma alternativa com grande potencial para o controle de bactérias multirresistentes é a utilização de bacteriocinas. O uso de diferentes bacteriocinas na prevenção e tratamento da mastite já foi descrito por diversos autores (BARBOSA-CORONA et al., 2009; CAO et al., 2007; SEARS et al., 1992). Entretanto, a necessidade de minimizar o 
uso de antibióticos em animais de produção, faz com que haja novo interesse na avaliação da atividade das bacteriocinas como alternativa na gestão de mastite (BASTOS et al., 2009). Bacteriocinas são peptídeos naturais sintetizados e secretados pelas bactérias, as quais inibem o crescimento de ambas as espécies estreitamente relacionadas e não relacionadas (JACK; TAGG; RAY, 1995).

Outra estratégia relevante é a utilização de lípides catiônicos. A atividade antibacteriana de lípides catiônicos de brometo/cloreto de dioctadecildimetilamônio (DDA) tem sido revisada (CARMONA-RIBEIRO; VIEIRA; LINCOPAN, 2006) podendo chegar a constituir um produto promissor para uso tópico de infecções humanas e veterinárias, incluindo mastite bovina. Além da atividade biocida, DDA possui a capacidade de adsorção a diferentes biomoléculas, e seu uso tem sido descrito como eficaz para o transporte de antígenos e/ou antibióticos (LINCOPAN et al., 2009).

A combinação de fármacos no tratamento de infecções pode contribuir para a prevenção ou redução da resistência bacteriana, ampliando o espectro de ação, além de diminuir a dose e a duração do tratamento, minimizando a toxicidade e possíveis efeitos colaterais (SILVA et al., 2011).

Neste cenário, o presente estudo teve como objetivo avaliar a atividade antibacteriana in vitro da bacteriocina nisina, de nanofragmentos de lípides sintéticos catiônicos de DDA e do complexo NS/DDA contra cepas de Staphylococcus spp. resistentes provenientes de mastite bovina e, cepas de $S$. aureus de uma International Culture Collection (ATCC ${ }^{\circledR}$ ). 


\section{REVISÃO DE LITERATURA}

\subsection{Mastite bovina}

Definida como inflamação das glândulas mamárias, a mastite é considerada a enfermidade de maior impacto econômico que acomete a pecuária leiteira mundial. Os principais prejuízos observados são queda na produção, assim como diminuição da qualidade, devido a alterações microbiológicas, físico-químicas, sensoriais e na composição centesimal do leite (SANTOS; FONSECA, 2007). Outras perdas ocasionadas pela mastite estão relacionadas com o descarte do leite de animais em tratamento, descarte prematuro de vacas por perda de um ou mais quartos mamários, redução do valor comercial desses animais, custos com diagnóstico microbiológico, medicamentos e com médico veterinário. Além disso, constitui ameaça à saúde dos consumidores devido à veiculação de patógenos e suas toxinas, ou pela presença de resíduos de antibióticos no leite (KEFEE, 2012).

A mastite é uma doença multifatorial complexa, e sua intensidade depende da interação entre fatores relacionados ao animal, ao homem, ao ambiente e o microrganismo. Pode ser ocasionada por traumas físicos, agentes químicos irritantes, mas, sobretudo pela colonização do canal do teto principalmente por bactérias, assim como fungos, leveduras e algas (RADOSTITS et al., 2002). A contaminação microbiana do leite pode ocorrer através da incorporação dos microrganismos que estão presentes no úbere ou durante o processo de ordenha, através do contato com utensílios e equipamentos de ordenha contaminados (FAGUNDES; OLIVEIRA, 2004).

A mastite pode ser classificada quanto sua forma de manifestação. A forma clínica apresenta os sinais evidentes da inflamação, tais como edema, hipertemia, endurecimento e dor na glândula mamária e/ou aparecimento de grumos, pus ou alterações das características do leite. Pode ocorrer também, febre, anorexia, com queda na produção de leite, podendo levar a morte do animal (TOZZETTI; BATAIER; ALMEIDA, 2008). Já a mastite subclínica não apresenta os sinais inflamatórios evidentes. Contudo, há alterações na composição do leite, tais como o aumento da contagem de células somáticas (CCS), aumento dos teores de sódio e cloro, proteínas séricas e diminuição do percentual de caseína, gordura, sólidos totais e lactose, além de ser responsável por aproximadamente $70 \%$ das perdas de leite ocasionadas pela doença (SANTOS; FONSECA, 2007).

Para o diagnóstico da mastite clínica, realiza-se exame criterioso da glândula mamária e o teste da caneca de fundo negro ou prova de Tamis, onde são observadas alterações macroscópicas nos primeiros jatos de leite. Por sua vez, o diagnóstico da mastite subclínica é 
baseado na elevação das células somáticas, principalmente os leucócitos polimorfonucleares. Pode ser realizado indiretamente pelo California Mastitis Test (CMT), que estima a viscosidade do leite após a adição de um reagente próprio, e diretamente através da CCS, que quantifica a elevação dessas células (ZAFALON et al., 2008).

Outra forma de classificação é referente à forma de transmissão, que pode ser contagiosa, causada por microrganismos adaptados à sobrevivência no úbere e que são disseminados do quarto infectado para outro sadio, ou de um animal para o outro no momento da ordenha. Geralmente são infecções subclínicas, podendo tornar-se crônica e com elevada CCS. Os principais agentes etiológicos são S. aureus, Streptococcus agalactiae, Mycoplasma bovis e Corynebacterium bovis (SANTOS; FONSECA, 2007). Já a mastite ambiental é ocasionada por microrganismos comumente presentes no meio ambiente do animal e que a partir dessa fonte alcançam o canal do teto. Geralmente é na forma clínica aguda, de curta duração (PHILPOT; NICKERSON, 1991). Os principais patógenos causadores das mastites ambientais são Streptococcus uberis e Streptococcus dysgalactiae, assim como os coliformes e os enterococos (HOGAN; SMITH, 2012).

\subsection{Mastite por Staphylococcus spp.}

Um dos principais agentes etiológicos isolados em infecções intramamárias bovina é Staphylococcus spp. Esses microrganismos apresentam implicações importantes em saúde pública, uma vez que são capazes de produzir diversos fatores de virulência, como a produção de toxinas que causam intoxicações alimentares, além de elevada resistência a diferentes antimicrobianos, o que contribui na sua persistência na glândula mamária (MATHEW; CISSELL; LIAMTHONH, 2007).

Staphylococcus spp. são caracterizados como cocos Gram-positivos, imóveis, com diâmetro variando entre 0,5 a $1,5 \mu \mathrm{m}$, anaeróbios facultativos, mesófilos e crescem em temperaturas entre 7 a 48,5 ${ }^{\circ} \mathrm{C}$. São capazes de se desenvolver em pH entre 4,2 a 9,3, com crescimento ótimo entre 7,0 a 7,5. Apresentam metabolismo fermentativo com produção de ácido e não gás, não formadores de esporos, catalase positivos e capazes de se multiplicarem em meio contendo 10\% de cloreto de sódio (KLOOS; BANNERMAN, 1999).

O gênero Staphylococcus é classificado em coagulase positiva e negativa, devido à habilidade de algumas espécies em coagular o plasma. S. aureus é o principal estafilococo coagulase positiva (CoPS) e é comumente isolado em mastite bovina em rebanhos de todo o 
mundo, representando importância econômica significativa devido sobretudo, à diminuição na quantidade e qualidade do leite (MARTINS et al., 2010).

S. aureus é um microrganismo altamente contagioso, que normalmente habita a pele e mucosas do homem e de outros animais. Pode também, colonizar a pele e o canal do teto e, uma vez infectado, o quarto passa a ser um reservatório do agente, ao qual se torna uma fonte de infecção e disseminação do patógeno no momento da ordenha (SANTOS; FONSECA, 2007). Geralmente causam mastite subclínica, com aumento variável de CCS. Porém, podem progredir para manifestações clínicas agudas, ao incluir sinais sistêmicos que variam de moderados a severos, como a gangrena dos quartos mamários, podendo levar à morte do animal (KEEFE, 2012).

Já Staphylococcus coagulase negativa, por muito tempo foram considerados como patógenos secundários, com menor importância em infecções intramamárias. Entretanto, atualmente são considerados patógenos emergentes e são frequentemente encontrados em amostras de leite de animais com mastite, principalmente em vacas primíparas no período pós-parto, com declínio após a segunda semana de lactação. Podem também ocasionar infecções persistentes, com aumento da CCS e diminuição da qualidade do leite, representando perdas econômicas significativas (PYÖR ÄLA; TAPONEN, 2009). São considerados oportunistas, pois normalmente fazem parte da microbiota da pele do teto e causam infecção via ascendente através do canal do teto (TRINIDAD; NICKERSON; ALLEY, 1990). Diversas espécies de CoNS já foram isoladas de amostras de leite bovino mastítico e as mais comuns são Staphylococcus chromogenes, Staphylococcus simulans e Staphylococcus epidermidis (PYÖRÄLA; TAPONEN, 2009).

Uma vez que o principal reservatório de Staphylococcus spp. é a pele do úbere dos animais infectados e as mãos dos ordenhadores, medidas de controle do patógeno devem estar relacionadas com as boas práticas de ordenha. A manutenção periódica e a higiene dos equipamentos e do ambiente de ordenha, assim como a higiene pessoal do ordenhador, a desinfecção dos tetos com solução desinfetante nos intervalos de pré e pós-ordenha, a terapia da vaca seca, a segregação de animais infectados e descarte de vacas com mastite crônica, auxiliam na diminuição da prevalência de mastite (KEEFE, 2012; ZAFALON et al., 2008).

\subsection{Fatores de virulência de Staphylococcus spp.}

A patogenicidade de Staphylococcus spp. está relacionada com a capacidade destes microrganismos em produzir uma gama de fatores de virulência associados à parede 
bacteriana ou que são secretados. Estas proteínas auxiliam a bactéria evadir-se do sistema imune do hospedeiro, assim como aderir, invadir ou destruir as células e se propagar dentro dos tecidos. Dentre esses fatores, incluem-se a produção de enterotoxinas, superantígenos, enzimas, citotoxinas e toxinas esfoliativas, assim como a produção de biofilmes (TRABULSI; TEIXEIRA; BUERIS, 2005).

As enterotoxinas estafilocócicas (SEs) são proteínas extracelulares de baixo peso molecular (22 a $29 \mathrm{kDa}$ ) produzidas durante o metabolismo bacteriano, e liberadas pela bactéria durante sua multiplicação. Existem diferentes enterotoxinas descritas na literatura, e as clássicas e de maior ocorrência são SEA, SEB, SEC, SED e SEE. As enterotoxinas são hidrossolúveis, resistentes às enzimas proteolíticas digestivas, termoestáveis, podendo permanecer no alimento mesmo após o cozimento, a pasteurização e a ultrapasteurização, e estão relacionadas com surtos de intoxicação alimentar (RAHIMI; ALIAN, 2013). Os sintomas de intoxicação alimentar estafilocócica envolvem náusea, êmese, dores abdominais e diarreia, assim como dores de cabeça, hipotensão e hipotermia, e é atribuída à ingestão dessas enterotoxinas (MARTIN; MYERS; LANDOLO, 2001).

As enterotoxinas são moléculas imunoestimuladoras altamente potentes, conhecidas como superantígenos (KONEMAN et al., 2001). Essas toxinas se ligam às moléculas do Complexo de Histocompatibilidade Maior (MHC) de classe II e aos receptores de células T, induzindo a proliferação de linfócitos T e a produção de interleucina 2 (IL-2). A formação deste complexo trimolecular resulta em uma produção maciça de citocinas que causarão um dano epitelial, que resultará em perdas capilares e hipotensão (BAKER; ACHARYA, 2004).

S. aureus é um dos principais contaminantes de leite e seus derivados e podem produzir um ou mais tipos de enterotoxinas nesses alimentos, representando um problema de saúde pública (LINA et al., 2004). Entretanto, a produção de enterotoxinas não está restrita aos $S$. aureus. Outras espécies de CoPS, como Staphylococcus hyicus e Staphylococcus intermedius, possuem importância à indústria alimentícia, assim como algumas espécies de CoNS, como Staphylococcus capitis, S. chromogenes e S. epidermidis também têm sido relatadas como produtoras de enterotoxinas (FRANCO; LANDGRAF, 2004).

A ocorrência de enterotoxinas estafilocócicas em produtos lácteos e derivados, especialmente em queijos, tem sido relatada por diversos autores. Borges et al. (2008) avaliaram o perfil de contaminação por Staphylococcus spp. e suas enterotoxinas em amostras de leite e derivados, de uma indústria de laticínios na região metropolitana de Fortaleza - CE. Os autores observaram que houve uma alta frequência de isolamento de CoPS, principalmente S. aureus, nas amostras de leite cru, enquanto que CoNS foi mais frequentemente isolado nas 
amostras de leite pasteurizado, coalhada e queijo. A presença de enterotoxina foi constatada em 20\% (4/25) das amostras de leite cru e, consequentemente, nas amostras de leite pasteurizado, coalhada e queijo, e foi atribuída à elevada presença de CoPS no leite cru.

Arcuri et al. (2010) pesquisaram a presença de genes de 11 diferentes enterotoxinas estafilocócicas em 291 cepas de $S$. aureus isoladas de mastite bovina, leite do tanque e queijo Minas frescal. Os autores observaram que 37,5\% $(n=109)$ dos isolados eram positivos para pelo menos um dos genes, e observaram também 23 genótipos diferentes de genes de toxinas distintas.

As citotoxinas estafilocócicas possuem atividade nas membranas celulares e compreendem as toxinas alfa, beta, delta e gama e a leucocidina de Panton-Valentine (PVL). São responsáveis por induzir mudanças pró-inflamatórias nas células, inativar o sistema imune por efeito citotóxico direto e degradar tecidos (KONEMAN et al., 2001). A toxina PVL provoca a destruição de leucócitos e necrose tecidual e está associada às cepas de $S$. aureus resistentes à meticilina isoladas da comunidade (ÜNAL; ÇINAR, 2012).

S. aureus também produz outras toxinas extracelulares como a toxina-1 da síndrome do choque tóxico (TSST-1) e toxinas esfoliativas (ETs). A TSST-1 é um superantígeno responsável pela síndrome do choque tóxico em humanos, caracterizada por febre, hipotensão, rash cutâneo e envolvimento multiorgânico. As toxinas esfoliativas promovem a clivagem do extrato granuloso da epiderme, ocasionando síndromes cutâneas severas, como a síndrome da pele escaldada e impetigo bolhoso (BANNERMAN; PEACOCK, 2007).

Outro importante fator de virulência de Staphylococcus spp. é a capacidade de produzir biofilmes, pois esta habilidade muitas vezes está relacionada com infecções recorrentes (MELCHIOR; VAARKAMP; GREMMELS, 2006). Os biofilmes são caracterizados como uma comunidade microbiana séssil envolta por uma matriz polimérica extracelular autoproduzida aderente a uma superfície inerte ou viva. Podem ser formados por uma única espécie de microrganismo, ou por diferentes espécies ou até mesmo gêneros, e são compostos principalmente por água e macromoléculas como polissacarídeos, proteínas, DNA, lipídeos, sais minerais e diversos produtos derivados da lise celular (COSTERTON; STEWART; GREENBERG, 1999; MONROE, 2007).

A formação de biofilmes no interior do tecido do úbere confere à bactéria capacidade de adesão e proteção contra os mecanismos de defesa do hospedeiro e ação dos agentes antimicrobianos, tornando a mastite uma doença persistente (ATULYA et al., 2014). As células bacterianas que crescem em um biofilme são geneticamente e fisiologicamente distintas das células livres, e podem ser mais tolerantes aos antibióticos em até 1.000 vezes 
(MONROE, 2007). Segundo Melchior, Vaarkamp e Gremmels (2006) as bactérias capazes de produzir biofilmes são mais frequentemente relacionadas às infecções crônicas e persistentes do que as cepas não produtoras. Além disso, os biofilmes auxiliam as bactérias aderirem e colonizarem as superfícies dos equipamentos de ordenha, o que favorece a disseminação do patógeno aos animais sadios (SANTOS; FONSECA, 2007).

Diversos trabalhos relatam a presença de genes e a capacidade fenotípica de formação de biofilmes por cepas de estafilococos isoladas de mastite bovina. Tremblay et al. (2013) avaliaram a capacidade fenotípica de 255 cepas de CoNS isoladas de casos de mastite, no Canadá. A maioria $(85,1 \%)$ dos isolados foi capaz de formar biofilme in vitro. Além disso, através da técnica de PCR, os autores observaram em 87,8\% dos isolados a presença de pelo menos um dos seis genes avaliados responsáveis pela formação de biofilme.

Castelani et al. (2013) avaliaram 110 S. aureus isolados de mastite de vacas e novilhas, e observaram que 55,5\% das cepas foram capazes de produzir biofilme fenotipicamente. Porém, a presença dos genes icaA e icaD, relacionados com a formação de biofilmes, foi detectada em $98,9 \%$ e $100 \%$ das amostras, respectivamente. Isso indica que existe uma elevada prevalência dos genes ica em S. aureus isolados de mastite, e que a expressão fenotípica depende de condições específicas de cultivo, como quantidade de glicose e condições hipóxicas (MELCHIOR; VAARKAMP; GREMMELS, 2006).

\subsection{Uso de antimicrobianos e mastite}

O desenvolvimento da antibicoticoterapia no século XX foi um marco para a história da humanidade, uma vez que se tornou possível o tratamento de diversas infecções. Porém, a utilização generalizada e excessiva fez com que surgissem patógenos multirresistentes às drogas de uso corrente, tanto em isolados de humanos, quanto veterinário (ASADUZZAMAN; SONOMOTO, 2009). Com isso, é cada vez mais frequente o relato de resistência antimicrobiana em todo o mundo, representando prejuízos tanto econômicos, como para a saúde. Segundo a Organização Mundial da Saúde (OMS) (2012), além do uso excessivo e a administração empírica, a utilização de antimicrobianos na promoção de crescimento de animais de produção aumenta a pressão seletiva sobre as bactérias, ocasionando a resistência.

Medidas de controle da mastite bovina empregadas nas propriedades leiteiras, como práticas de higiene de ordenha, muitas vezes são ineficazes e exigem intervenção de medicamentos (OLIVER; MURINDA, 2012). Agentes antimicrobianos são comumente 
empregados para o tratamento e prevenção da mastite bovina, em terapia de vaca seca, bem como em outras doenças que acometem o gado leiteiro (SAWANT; SORDILLO; JAYARAO, 2005). Entretanto, o uso constante e sem prévia identificação do agente etiológico e ensaios de susceptibilidade, favorecem a propagação de cepas multirresistentes (SZWEDA et al., 2014), podendo contribuir para o aumento da morbidade e mortalidade dos animais, aumentando os custos de produção (MATHEW; CISSELL; LIAMTHONH, 2007). Além disso, essas cepas podem transferir os genes de resistência a outras bactérias sensíveis (NISHIE; NAGAO; SONOMOTO, 2012).

Diferentes drogas são utilizadas para o tratamento e a prevenção da mastite. As cefalosporinas são as mais utilizadas, bem como as lincosamidas e beta-lactâmicos (OLIVER; MURINDA, 2012). Porém, muitos trabalhos conduzidos em diferentes países evidenciam que Staphylococcus spp. isolados de casos de mastite bovina apresentam resistência a esses e também a outros agentes antimicrobianos. Em rebanhos dos Estados Unidos, Erskine et al. (2002) encontraram resistência à ampicilina e penicilina em 49,6\% das cepas de S. aureus, $0,2 \%$ ao ceftiofur, $2,1 \%$ à pirlimicina e $0,6 \%$ à oxacilina. Na Estônia, Kalmus et al. (2011) avaliaram o perfil de resistência de cepas de $S$. aureus e CoNS e observaram que 61,4 e $34,5 \%$ eram resistentes à penicilina, 59,5 e 38,5\% à ampicilina, 18,1 e 17,1\% à clindamicina, 4,1 e 11,6\% resistentes à tetraciclina, respectivamente. No Brasil, da Costa et al. (2013) traçaram o perfil de resistência de $352 \mathrm{~S}$. aureus isolados de 35 rebanhos do estado de Minas Gerais, e encontraram índice de resistência de 0,40\% para ceftiofur, 1,69\% para gentamicina, $3,35 \%$ para neomicina e $34,1 \%$ para penicilina.

A utilização de antimicrobianos em vacas leiteiras pode também gerar resíduos no leite. A presença desses resíduos constitui prejuízos econômicos, uma vez que o leite dos animais em tratamento deve ser descartado, e os produtores são penalizados pelo leite adulterado. Além disso, a ocorrência destes resíduos acarreta problemas de ordem tecnológica à indústria de laticínios, pois inibem as culturas lácteas utilizadas na fabricação dos derivados e produtos fermentados, dificultando a produção ou alterando a qualidade (ADETUNJI, 2011).

Os resíduos de antibióticos em derivados lácteos também podem ocasionar desequilíbrio da microbiota intestinal do consumidor, reações de hipersensibilidade e tóxicas, além de efeitos teratogênicos (JACOBSON; CONSUMER, 2003). A ingestão contínua de pequenas doses de antibióticos através do leite contaminado, principalmente por crianças, reduz a microbiota normal, permitindo a proliferação dos microrganismos patogênicos e interferindo diretamente na eficácia de outros medicamentos (ALMEIDA et al., 2003). 
Estima-se que cerca de $20 \%$ do leite bovino brasileiro seja produzido de forma informal e comercializado sem nenhuma inspeção sanitária. Tal prática representa risco à saúde da população, devido ao consumo de um produto de baixa qualidade e que possa conter resíduos de antimicrobianos, assim como microrganismos patogênicos e suas toxinas (MOTTA et al., 2013). A presença de resíduos de antimicrobianos no leite é devida, principalmente ao uso abusivo e inadequado de antibióticos e da não obediência ao período de carência. Ainda, fatores como o prolongamento da retenção do medicamento na glândula mamária em alguns animais e a antecipação do parto, também podem contribuir (COSTA et al., 2000).

Resíduos de antibióticos em leite bovino já foram detectados em diferentes regiões do Brasil. Em Minas Gerais, Cerqueira et al. (2014) relataram uma baixa concentração de resíduos de quinolonas, estreptomicinas e tetraciclinas em amostras de leite de tanque de expansão de diferentes propriedades. No Paraná, Vieira et al. (2012) demonstraram a presença de resíduos de tetraciclina, gentamicina, estreptomicina e beta-lactâmicos em amostras de leite pasteurizado tipo B de estabelecimentos comerciais. Ainda, foi encontrado resíduo de cloranfenicol em $40 \%$ das amostras analisadas. O cloranfenicol possui efeito tóxico e seu uso em animais de produção é proibido no Brasil.

Além de resíduos no leite, o emprego de antibióticos na criação animal pode gerar resíduos no meio ambiente, de forma direta, através das fezes e urina, ou indireta, através da utilização de esterco animal na adubação de culturas (CHRISTIAN et al., 2003; KEMPER, 2008). Essas moléculas podem ser detectadas em amostras de solo, água superficial e subterrânea e impactar negativamente os organismos aquáticos e terrestres (toxicidade crônica ou aguda). Esses resíduos podem também, favorecer a seleção de microrganismos resistentes aos antimicrobianos (KEMPER, 2008).

Agentes antimicrobianos podem ainda estimular a formação de biofilmes bacterianos. Estudos mostraram que alguns antibióticos, quando presentes em concentrações subinibitórias (sub-MICs) podem induzir de forma significativa a formação de biofilme in vitro em diferentes espécies bacterianas, incluindo S. aureus (FRANK et al., 2007; LÁZARODÍEZ et al., 2016). Rachid et al. (2000) demonstraram que concentrações sub-MICs de tetraciclina e estreptogramina semi-sintética quinupristina-dalfopristina foram capazes de estimular a expressão dos genes ica, responsáveis pela adesão intercelular na matriz do biofilme, de nove a 11 vezes, em S. epidermidis. Concentrações sub-MICs, podem ainda, influenciar a expressão de fatores de virulência, tais como outras moléculas de adesão ou toxinas (MELCHIOR; VAARKAMP; GREMMELS, 2006). 


\subsection{Resistência antimicrobiana em Staphylococcus spp.}

A resistência antimicrobiana pode ser intrínseca, que é naturalmente exibida por todos os microrganismos de determinada espécie, e adquirida, resultante da aquisição de genes de resistência veiculados por elementos genéticos móveis, como plasmídeos e transposons, e através de mutação de genes reguladores ou estruturais. Esses genes codificam diferentes mecanismos bioquímicos que impedem a ação das drogas (ALTERTHUM, 2005).

Staphylococcus spp. demonstraram, ao longo do tempo, notável capacidade de desenvolver resistência à maioria dos antimicrobianos. A resistência aos beta-lactâmicos pode ocorrer por dois mecanismos principais. Um deles é através da hidrólise enzimática pela ação da enzima beta-lactamase. Essas enzimas extracelulares, codificada pelo gene blaZ, clivam o anel beta-lactâmico no espaço periplasmático e degradam o antibiótico (NIKAIDO, 2009). O outro mecanismo de resistência é pela aquisição do gene $m e c A$, que confere resistência à meticilina, e consequentemente, tornam os microrganismos intrinsecamente resistentes também a outras drogas beta-lactâmicas, podendo apresentar resistência adicional para aminoglicosídeos, macrolídeos, tetraciclinas e quinolonas (LEE, 2003; SAHM, 1994). O gene cromossômico mecA confere modificações nas proteínas de ligação de penicilina (Protein Binding Penicilin - PBP) presentes na membrana plasmática, dando origem a variantes PBPs (PBP 2 ou PBP 2a), as quais tem baixa afinidade para os beta-lactâmicos (CHAMBERS, 1997). Esses dois mecanismos de resistência podem estar presentes numa mesma cepa, e até estarem interagindo entre si (de LENCASTRE et al., 1991).

A resistência aos beta-lactâmicos é amplamente distribuída em cepas de Staphylococcus spp. isoladas de mastite bovina. No Brasil, a presença do gene blaZ foi observada por Krewer et al. (2015) em 93,1\% (203/218) das cepas isoladas de rebanhos bovinos do Nordeste. Também foi encontrado no Rio de Janeiro 5,2\% (13/250) de cepas blaZ positivas (MENDONÇA et al., 2012). Na Polônia, Szweda et al. (2014) analisaram 123 cepas de $S$. aureus e observaram que 25 de 29 cepas de $S$. aureus resistentes à penicilina transportavam o gene blaZ. Além disso, duas cepas foram positivas para o gene mecA. A prevalência de Staphylococcus spp. resistentes a meticilina geralmente é baixa, quando comparadas com isolados clínicos humanos (VANDERHAEGHEN et al., 2010). Coelho et al. (2009) detectaram a presença do gene mecA em 25\% (5/21) das cepas MRSA isoladas de vacas com mastite subclínica no Rio de Janeiro. Na Índia, Kutar et al. (2015) encontraram 9,61\% (5/52) de cepas de S. aureus, isoladas de mastite de vacas e búfalas, carregando o gene $m e c A$. Em rebanhos chineses, Pu et al. (2014) observaram que apesar de 47,6\% (49/103) dos 
isolados serem mecA positivos, 37 destas cepas apresentaram sensibilidade fenotípica à oxacilina, ressaltando a importância do emprego de métodos genotípicos.

Os macrolídeos, lincosamidas e estreptogramina B $\left(\mathrm{MLS}_{\mathrm{B}}\right)$ apesar de serem antimicrobianos quimicamente distintos, apresentam mecanismos de ação similar, atuando na ligação do ribossomo e inibição da síntese protéica bacteriana (JUYAL et al., 2013). A resistência a essas drogas está relacionada com dois diferentes mecanismos: (1) modificações no alvo de ligação do antimicrobiano no ribossomo, mecanismo codificado pelos genes ermA ou ermC (erythromycin ribosomal methylase), que codificam enzimas denominadas de metilases RNAr 23s, responsáveis pela metilação do RNAr 23s, as quais conferem resistência cruzada aos $\mathrm{MLS}_{\mathrm{B}}$; (2) efluxo ativo: codificado pelo gene mrsA (specific methionine sulfoxide reductase), o qual confere resistência aos macrolídeos e estreptogramina B (LEWIS; JORGENSEN, 2005).

As tetraciclinas são antibióticos de amplo espectro utilizados numa variedade de infecções ocasionadas por microrganismos Gram-positivos e Gram-negativos. Os mecanismos de resistência às tetraciclinas incluem: (1) as proteínas de efluxo, que protegem o ribossomo da ação da droga, e são codificadas pelo gene tet, uma superfamília de proteínas; (2) proteínas de proteção ribossomal, que ocorre por ligação de proteínas ao ribossomo, tornando-o inacessível ao fármaco e, (3) a inativação enzimática da tetraciclina, codificada pelo gene tet $X$ (SPEER; SHOEMAKER; SALYERS, 1992; ULLAH et al., 2012).

Em um trabalho conduzido na Turquia por Türkyilmaz et al. (2010), isolou-se 93 cepas de $S$. aureus de mastite bovina, onde 17\% eram MRSA e resistentes a múltiplas drogas. Além disso, 15 cepas foram resistentes à tetraciclina e continham o gene tetM, mas nenhuma continha o gene tetK. Entre as cepas resistentes à eritromicina, nove possuíam o gene ermA, sete tinham tanto o gene ermA quanto $\operatorname{ermB}$, porém nenhuma albergava o gene ermC.

Em estafilococos, a resistência aos fenicóis, lincosamidas pleuromutilinas, estreptogramina A e macrolídeos, assim como linezolida é mediada pelo gene $c f r$. Este gene encontra-se frequentemente em plasmídeos, e pode ser disseminado entre bactérias da mesma espécie, e também entre espécies diferentes. O gene $c f r$ já foi identificado em isolados de estafilococos linezolida-resistentes de origem humana. Em animais, cepas carregando o gene $c f r$ têm sido identificas em suínos, equinos e aves. Em bovinos, o gene $c f r$ já foi identificado em quatro espécies (Staphylococcus lentus, S. simulans, S. sciuri e MRSA) (SHEN; WANG; SCHMARZ, 2013). 


\subsection{Alternativas de tratamento e profilaxia para infecções produzidas por $\underline{\text { Staphylococcus }}$ spp.}

\subsubsection{Bacteriocinas}

A reduzida quantidade de antibacterianos clinicamente efetivos, disponíveis para o tratamento de infecções causadas por microrganismos multirresistentes, tem aumentado a necessidade de procura por alternativas de tratamento. A utilização de bacteriocinas tem sido considerada uma opção vantajosa, uma vez que tem sido demonstrada a sua atividade contra patógenos de importância clínica humana e veterinária (NIGAM; GUPTA; SHARMA, 2014).

Bacteriocinas são peptídeos ou proteínas ribossomais biologicamente ativas, produzidas pela própria bactéria, que destroem ou inibem o crescimento de outras bactérias taxonomicamente relacionadas com a cepa produtora. São compostos que surgiram durante a evolução dos sistemas de defesa microbiana, e são utilizados pelas bactérias para competir com sucesso para a sua sobrevivência (SCHULZ et al., 2003). Os genes responsáveis pela produção das bacteriocinas estão localizados em plasmídeos, transposons ou cromossomos bacterianos, e consistem geralmente de um operon de vários genes permitindo a biossíntese, modificação pós-tradução, transporte, bem como o gene de imunidade e, em alguns casos, um gene que causa a lise do produtor para liberação da bacteriocina ativa (CLEVELAND et al., 2001; McAULIFFE; ROSS; HILL, 2001).

As bacteriocinas de bactérias ácido-lácticas (BAL) são divididas em quatro classes, baseadas na massa molar e a estrutura química, assim como o espectro e o mecanismo de ação (CLEVELAND et al., 2001):

- Classe I (lantibióticos): constituída por peptídeos termoestáveis de baixa massa molar $(<5 \mathrm{kDa})$, com aminoácidos que apresentam em sua composição lantionina e $\beta$ metillantionina. Pode ser dividida em subclasses, baseadas em sua estrutura e mecanismo de ação: tipo A- moléculas lineares, como a nisina, subtilina e epidermina; tipo $B$ - moléculas globulares, como a mersacidina e mutacina.

- Classe II: constituída de pequenos peptídeos (<10 kDa) relativamente estáveis ao calor. São peptídeos de membrana ativa que não contêm lantionina, subdivididos em: classe IIa- ativos contra Listeria monocytogenes, com sequência N-terminal definida, dentre elas a leucocina A, mesentericina Y105 e carnobacteriocina B2; classe IIbcomplexos, que requerem dois diferentes peptídeos para que tenham atividade (lactacina $\mathrm{F}$ e lactococina $\mathrm{G}$ ); classe IIc- peptídeos com tiol ativado, que requerem 
resíduos de cisteína reduzidos para que sejam ativos (enterocina AS48, circularina A e reutericina 6).

- Classe III: constituída por proteínas termolábeis de alta massa molar (>30 kDA), de natureza complexa quanto à atividade e estrutura. Promovem a lise da parede celular das células sensíveis. As bacteriocinas pertencentes a essa classe são: lactacinas A e B, helveticinas J e V-1829 e acidophilucina A.

- Classe IV: bacteriocinas complexas que, além da porção protéica, contém porções de aminoácidos, carboidratos ou lipídeos em sua composição, como a plantaricina $S$, leuconocina S e lactocina 27 (KLAENHAMMER, 1993; RAJARAM et al., 2010).

\section{$\underline{\text { 2.6.1.1 }}$ Nisina}

O efeito inibitório da nisina sobre o crescimento de outras BAL foi observado pela primeira vez em 1928, pelos pesquisadores Rogers e Whittier (HARRIS; FLEMING; KLAENHAMMER, 1992). Esse lantibiótico, produzido por cepas de Lactococcus lactis subsp. lactis é ativo em concentrações nanomolares e possui atividade contra muitas espécies de bactérias Gram-positivas, incluindo cepas resistentes à fármacos e patógenos de origem alimentar, assim como em células vegetativas e esporos de Clostridium e Bacillus (McAULIFFE; ROSS; HILL, 2001). Além disso, bactérias Gram-negativas podem apresentar sensibilidade à nisina quando associada com agentes quelantes, como EDTA, ácidos e detergentes, ou expostas a tratamentos físicos, como choque osmótico, que alteram a estabilidade e causam danos à membrana externa da bactéria (CASTELLANO; BELFIORE; VIGNOLO, 2011; PARADA et al., 2007).

Dentre todas as bacteriocinas conhecidas, a nisina é a única aceita pelo FDA (Food and Drug Administration) e tem sido utilizada como conservante alimentar em diversos países para diversas finalidades, sem o aparecimento de resistência bacteriana significativa (CHATTERJEE et al., 2005). No Brasil, a nisina é aprovada para uso em produtos lácteos no limite máximo de $12,5 \mathrm{mg} / \mathrm{kg}$ e é muito utilizada em produtos cárneos, sendo permitida sua utilização na superfície externa de embutidos de diferentes tipos (SCHULZ et al., 2003). É considerada pelo comitê do Codex Alimentarius da FAO (Food and Agriculture Organization) como uma substância GRAS (Generally Recognized As Safe) (MELO; SOARES; GONÇALVES, 2005), e sua ingestão não causa efeitos tóxicos ao organismo. Sua $\mathrm{DL}_{50}$ (Dose Letal 50\%) é $6950 \mathrm{mg} / \mathrm{kg}$ e é comparável ao de sais comuns, como o cloreto de sódio. Com bases em estudos toxicológicos realizados em animais, a OMS recomenda que a 
Ingestão Diária Aceitável (IDA) de nisina é de 33.000 UI/kg $(0,825 \mathrm{mg})$ de peso corpóreo (HOOVER; STEENSON, 1993).

A maioria dos estudos sobre a utilização biotecnológica da nisina é focada na indústria de alimentos, seja pela adição direta da molécula purificada, seja pela adição de culturas lácticas (NASCIMENTO; MORENO; KUAYE, 2008). Contudo, seu potencial terapêutico na medicina humana e veterinária tem sido estudado. Aranha, Gupta e Reddy (2004) comprovaram o efeito contraceptivo da nisina, tanto in vitro como in vivo. Seu emprego no tratamento e prevenção da cárie bacteriana foi demonstrado por Tong et al. (2010). Le Lay et al. (2008) demonstraram que a nisina foi capaz de inibir o crescimento de hifas de Candida albicans. Além disso, a nisina representa uma alternativa eficiente para o tratamento e prevenção das mastites bovinas. Em 1989, Broadbent et al. observaram que a nisina foi capaz de inibir o crescimento de diferentes patógenos Gram-positivos causadores de mastite bovina, dentre eles enterococos, estafilococos e estreptococos. Em ensaios de campo, infecções intramamárias foram produzidas por inoculação intramamária ou exposição do teto ao patógeno. Após o tratamento intramamário com nisina, altas taxas de cura foram observadas (66\% para S. aureus, 95\% para Strep. agalactiae e 100\% para Strep. uberis). Além disso, foi observada uma redução significativa de células somáticas nas glândulas curadas (DELVESBROUGHTON et al., 1996).

A molécula da nisina é formada por anéis de lantionina e 34 aminoácidos com caráter catiônico e hidrofóbico, com peso molecular de 3,5 kDa (CARR; CHILL; MAIDA, 2002). Também contém alguns aminoácidos não catiônicos, raramente encontrados na natureza, como a didehidroalanina (Dha) e a didehidrobutirina (Dhb). Esse peptídeo é considerado uma molécula anfipática, pois possui resíduos hidrofóbicos na região $\mathrm{N}$-terminal e hidrofílicos na região C-terminal (Figura 1). Quimicamente, sua solubilidade, estabilidade e atividade biológica estão relacionados com pH, sendo mais estável em pH ácido (2-5) (ARAUZ et al., 2009). Além disso, a nisina é estável à tratamentos térmicos, podendo ser autoclavada a 121 ${ }^{\circ} \mathrm{C}$ por 15 minutos, em pH 2-3, sem ocorrer desnaturação e perda de atividade menor que $10 \%$ (DELVES-BROUGHTON, 2005). 
Figura 1 - Representação esquemática da estrutura primária da nisina. Os resíduos de lantionina (Ala-S-Ala) e $\beta$ metillantionina (Abu-S-Ala) que formam os anéis de lantionina estão em vermelho; os aminoácidos desidratados Dhb (didehidrobutirina) e Dha (didehidroalanina) estão em laranja.

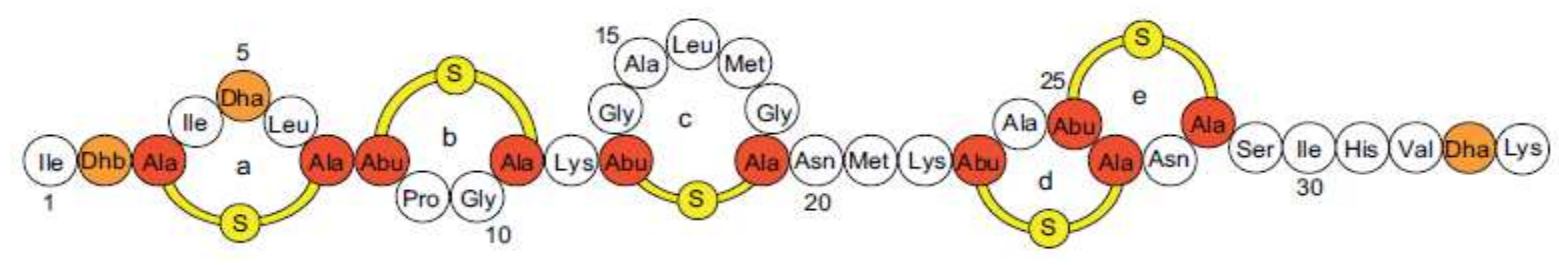

Fonte: Kruijff; van Dam e Breukink (2008).

O mecanismo de ação das bacteriocinas é dependente de características inerentes à sua molécula e de fatores relacionados à espécie bacteriana e de suas condições de crescimento. A ação pode ser bactericida ou bacteriostática. Geralmente, as bacteriocinas se ligam à receptores de membrana celular da bactéria alvo (OLIVEIRA; SIQUEIRA JR.; SILVA, 2012).

De um modo geral, a nisina possui dois principais mecanismos de ação (Figura 2). Um deles é através da formação de poros na membrana celular bacteriana. Primeiramente, ocorre a adsorção não específica e reversível da nisina sobre a parede celular da bactéria. Esse fenômeno é dependente do pH $(3,0-6,5)$, da composição fosfolipídica da membrana citoplasmática, da presença de cátions divalentes e trivalentes e da concentração utilizada. Em seguida, a nisina torna-se insensível às proteases e se liga ao lípide II da membrana fosfolipídica da bactéria por ligação eletrostática. Essa ligação ocasiona dissipação da força próton-motriz, alterando o potencial de membrana e o gradiente de concentração de prótons, formando poros na membrana citoplasmática. Esses poros induzem a um rápido efluxo de moléculas intracelulares essenciais, levando a lise celular (MORENO et al., 1999; NISHIE; NAGAO; SONOMOTO, 2012).

O segundo mecanismo de ação da nisina é sobre a síntese da parece celular bacteriana (JOSALA et al., 2009). A parede das bactérias Gram-positivas compreende de múltiplas camadas de peptidoglicano intercaladas com ácido teicóico e ácido lipoteicóico. O lípide II é um precursor da parede celular ancorado à membrana e é essencial para a biossíntese da parede bacteriana, e compreende de um transportador de peptidoglicano do citoplasma para a parede. A ligação da nisina com o lípide II impede esse transporte. Além disso, a nisina também se liga ao lípide III e lípide IV, interferindo na biossíntese de ácido teicóico e ácidos lipoteicóicos. Sendo assim, além de interferir com a biossíntese da parede celular, a nisina também pode inibir a formação de outros componentes estruturais essenciais do envelope celular (YOUNT; YEAMAN, 2013). 
Figura 2 - Representação esquemática dos mecanismos de ação da nisina: A nisina se liga ao lípide II presente na membrana citoplasmática da bactéria, formando poros, assim como impedindo a síntese do peptidoglicano.

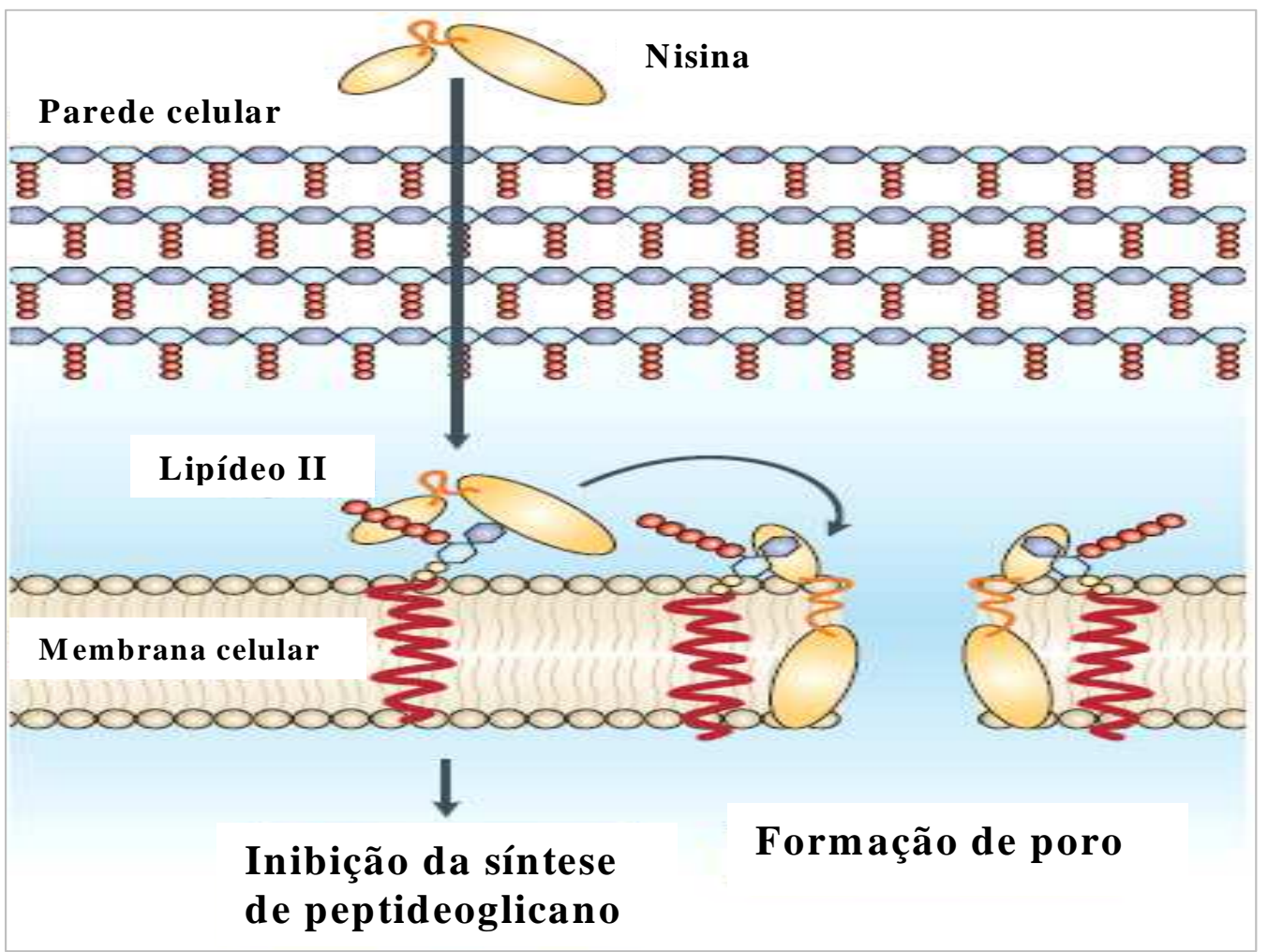

Adaptado de: Cotter; Ross e Hill (2013).

Outra atividade biológica da nisina é a inibição da germinação dos esporos de espécies de Bacillus e Clostridium. Propõe-se que haja uma interação entre o resíduo de diidroalanina na posição 5 da nisina com grupos sulfidrila vitais da membrana dos esporos recémgeminados, exercendo um profundo efeito bacteriostático, e consequentemente inibição do esporo (ASADUZZAMAN; SONOMOTO, 2009).

\subsubsection{Brometo de dioctadecildimetilamônio (DDA)}

As bactérias, assim como os fungos, são carregadas negativamente e interagem com um grande número de compostos carregados positivamente, que atuam como agentes antimicrobianos (CARRASCO; SAMPAIO; CARMONA-RIBEIRO, 2015). Compostos de amônio quaternários positivamente carregados são muito úteis como antissépticos e desinfetantes, e são empregados em diversos fins clínicos, como desinfecção pré-operatória de pele intacta, aplicação em membranas mucosas e desinfecção de superfícies não críticas. Além disso, são também excelentes para a limpeza de superfícies inertes e desodorização (CARMONA-RIBEIRO; CARRASCO, 2013). 
O brometo de dioctadecildimetilamônio (DDA) é caracterizado como um lípide catiônico sintético, positivamente carregado (PM 631) com um brometo ou um cloreto como contra-íon, e duas longas cadeias alifáticas hidrocarbonadas $\mathrm{C}_{18}$ altamente hidrofóbicas, ligadas a uma amina quaternária (Figura 3). Sua molécula é pouco solúvel em água devido a cadeias lipofílicas. Entretanto, através de sonicação com sonda de titânio podem ser obtidas vesículas fechadas ou fragmentos de bicamadas (bicelas) (CARMONA-RIBEIRO; CHAIMOVICH, 1983; VIEIRA; CARMONA-RIBEIRO, 2001). O processo de sonicação aumenta a curvatura das vesículas, assim como as destrói, rompendo-as e formando esses fragmentos de bicamada (com raio infinito, ou curvatura zero), aumentando desse modo a $\mathrm{T}_{\mathrm{M}}$. Quando submetidas à extrusão ou sonicação, as estruturas grandes e gigantes são rompidas, formando vesículas pequenas e achatadas (FEITOSA; BARRELEIRO; OLOFSSON, 2000). A dispersão lipídica usando sonda que emite ultrassom em solução aquosa produz bicelas catiônicas ao invés de vesículas esféricas fechadas. Estes fragmentos são estabilizados em baixa força iônica ( $\leq 5 \mathrm{mM}$ de sal) pela repulsão eletrostática (CARMONA-RIBEIRO et al., 1991; PANSU et al., 1990).

Figura 3 - Estrutura química do DDA.

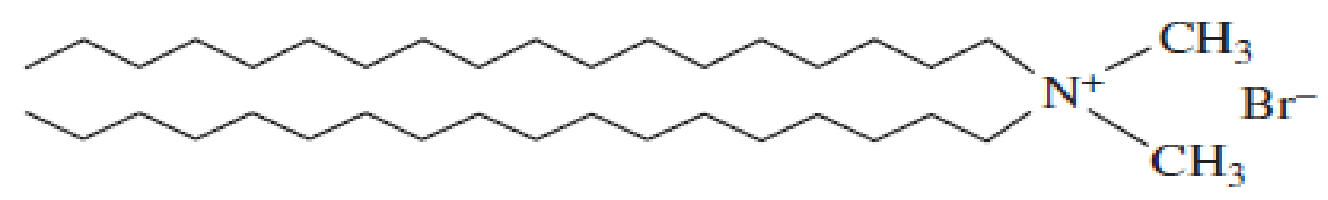

Fonte: Lincopan e Carmona-Ribeiro (2006).

O DDA é um potente agente biocida e tem sido utilizado em soluções antissépticas e desinfetantes, como agentes antimicrobianos contra fungos e bactérias (CARMONARIBEIRO; VIEIRA; LINCOPAN, 2006). Sua ação bactericida em concentrações micromolares foi comprovada contra diferentes espécies de bactérias de importância clínica (E. colli, Salmonella typhymurium, P. aeruginosa e S. aureus). Após 5 horas de interação entre concentrações $1 \times 10^{7} \mathrm{UFC} / \mathrm{mL}$ e $5 \mu \mathrm{M}$ DDA, não foi possível a contagem de células viáveis (0\% de sobrevivência) (MARTINS; MAMIZUKA; CARMONA-RIBEIRO, 1997). Formulações a base de fragmentos de bicamadas de DDA, obtidos por sonicação, e anfotericina B foram eficazes contra candidíase sistêmica em camundongos, e exibiu feito sinérgico in vitro com miconazol contra Candida albicans, com substancial redução de doses para a ação fungicida (LINCOPAN; CARMONA-RIBEIRO, 2006; PACHECO; 
CARMONA-RIBEIRO, 2003). Além disso, Carrasco, Sampaio e Carmona-Ribeiro (2015) demonstraram que, moléculas de DDA sozinhas e/ou associadas com carboximetilcelulose, exibem atividade de largo espectro contra microrganismos multirresistentes, incluindo bactérias Gram-negativas e Gram-positivas, além de fungos.

Adicionalmente, através de atração eletrostática, esses lípides catiônicos permitem a adsorção de uma ampla variedade de biomoléculas, geralmente negativamente carregadas, e tem sido utilizados para carregar antígenos e/ou antibióticos (LINCOPAN et al., 2009) (Figura 4). Em um trabalho conduzido por Barbassa, Mamizuka e Carmona-Ribeiro (2011), foi evidenciado que fragmentos de bicamada de DDA são eficazes tanto como agente micobactericida, como molécula de transporte para rifampicina contra patógenos da tuberculose.

Figura 4 - Modelo de bicela carregando uma droga na borda. Drogas com carga negativas podem interagir com a cabeça polar catiônica do DDA por atração eletrostática dos compostos. Assim como, bordas hidrofóbicas das bicelas de DDA podem auxiliar essa incorporação pela hidrofobicidade de algumas drogas diretamente com a borda hidrofóbica.

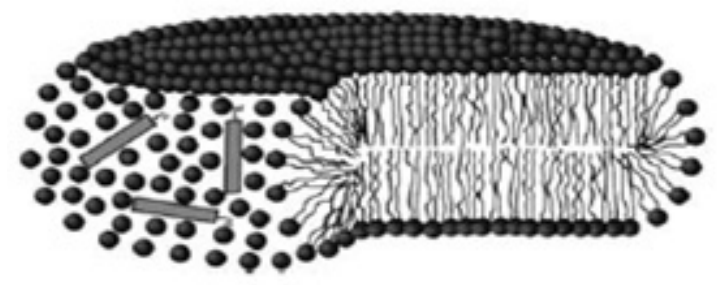

Fonte: Oliveira; Benati e Lamy (2011).

Esses fragmentos de bicamada são também eficientes imunoadjuvantes para a indução de resposta imune, tanto humoral quanto celular, aumentando a resposta imunológica contra microrganismos, proteínas e peptídeos, entre outros. Desde a década de 70, Veronesi, Correa e Alterio (1970) demonstraram a capacidade do DDA de estimular a produção de anticorpos contra toxóide tetânico absorvido ao hidróxido de alumínio. Vesículas de DDA também já foram empregadas para indução da resposta imunológica contra antígenos tumorais (PRAGER et al., 1985) e contra o vírus da doença de Newcastle (KATZ et al., 1993).

O mecanismo de ação bactericida do DDA acontece através da reversão da carga da superfície celular, de negativa para positiva, fazendo com que haja uma desorganização da membrana, seguida de extravasamento do material intracelular de baixo peso molecular e, consequentemente morte do microrganismo (CARMONA-RIBEIRO; CARRASCO, 2013; HUGO, 1999). Primeiramente, ocorre a adsorção e penetração dos agentes catiônicos dentro da parede celular bacteriana. Em seguida, ocorre uma reação com a membrana citoplasmática 
(lipídeos ou proteínas), seguida de desorganização da membrana, e vazamento de material de baixo peso molecular intracelular, degradação de proteínas e ácidos nucléicos (CARMONARIBEIRO; CARRASCO, 2013). Entretanto, diferentemente de outros lípides cationicos que lisam a célula, o DDA atua possivelmente ocasionando danos na função das proteínas ao nível da parede externa bacteriana, em que as vesículas se aderem sem romper-se e nem lisar as células (CAMPANHÃ; MAMIZUKA; CARMONA-RIBEIRO, 1999).

Quanto ao efeito citotóxico do DDA, Carmona-Ribeiro et al. (1997) demonstraram que células de mamíferos são mais resistentes ao DDA que as células bacterianas ou fúngicas. Cinquenta por cento de fibroblastos continuaram viáveis quando tratados com $1 \mathrm{mM}$ de DDA em baixa força iônica, enquanto que para os microrganismos, $50 \%$ de viabilidade ocorreu em concentrações micromolares de DDA. Em concentrações bactericidas para bactérias e fungos, cerca de $100 \%$ de células de mamíferos se mantiveram viáveis. Esses resultados estão ilustrados na Tabela 1.

Tabela 1 - Efeito citotóxico do DDA contra células de mamíferos, bactérias e levedura.

\begin{tabular}{lcc}
\hline \multicolumn{1}{c}{ Tipo de célula } & $\begin{array}{c}\text { Concentração de células } \\
\text { viáveis (células/mL) }\end{array}$ & $\begin{array}{c}\text { Concentração de DDA para } \\
\mathbf{5 0 \%} \text { de sobreviventes (mM) }\end{array}$ \\
\hline $\begin{array}{l}\text { Fibroblasto de camundongo Balb-c 3T3 } \\
\text { normais (clone A31) }\end{array}$ & $1 \times 10^{4}$ & 1,000 \\
Fibroblasto de camundongo SVT2 (SV40 & $1 \times 10^{4}$ & 1,000 \\
transformados) & $2 \times 10^{6}$ & 0,010 \\
Candida albicans & $2 \times 10^{7}$ & 0,028 \\
Escherichia coli & $2 \times 10^{7}$ & 0,010 \\
Salmonella typhimurium & $3 \times 10^{7}$ & 0,005 \\
Pseudomonas aeruginosa & $3 \times 10^{7}$ & 0,006 \\
Staphylococcus aureus &
\end{tabular}

Adaptado de: Carmona-Ribeiro (2003).

Com a emergência e disseminação de bactérias resistentes, o tratamento da mastite bovina tem se transformado em um desafio para a medicina veterinária e o agronegócio. Por um lado, muitos dos agentes antibacterianos utilizados como primeira escolha terapêutica tem perdido a sua efetividade, perante a expressão de diferentes mecanismos de resistência adotados pelos agentes etiológicos da mastite bovina (RUEGG et al., 2015). Por outro lado, o uso de antibacterianos de amplo espectro tem comprometido as características organolépticas do leite, além de gerar resíduos que, direta ou indiretamente, afetam os derivados lácteos e a microbiota de ecossistemas que estão em contato direto com estes resíduos (ADETUNJI, 2011). Assim, estudos que contemplem esta problemática e visem à procura de alternativas de tratamento, são dignos de investigação. Neste sentido, no presente estudo, foi avaliada a 
atividade da bacteriocina nisina e do lípide catiônico sintético DDA, e a sua combinação, contra os principais agentes de mastites identificados em estudos prévios. 


\section{OBJETIVOS}

Avaliar a atividade antibacteriana in vitro da bacteriocina nisina, de nanofragmentos de lípides sintéticos catiônicos de DDA e do complexo NS/DDA contra Staphylococcus spp. resistentes provenientes de mastite bovina e de cepas de $S$. aureus de uma International Culture Collection (ATCC ${ }^{\circledR}$ ).

\subsection{Objetivos específicos}

- Caracterizar o perfil de sensibilidade antimicrobiana in vitro dos isolados frente aos antibióticos mais frequentemente utilizados na clínica médica humana e veterinária;

- Avaliar a atividade antibacteriana in vitro da bacteriocina nisina;

- Avaliar a atividade antibacteriana in vitro de nanofragmentos de lípides sintéticos catiônicos de DDA;

- Avaliar a interação in vitro do complexo NS/DDA (Nisina/DDA);

- Caracterizar as partículas de nisina, DDA e do complexo NS/DDA através do tamanho e polidispersão e carga de superfície. 


\section{MATERIAL E MÉTODOS}

\subsection{Cepas bacterianas}

Inicialmente, para a seleção de cepas a serem incluídas no estudo, foram triadas 269 cepas de Staphylococcus spp. (102 S. aureus e 167 CoNS) isoladas a partir de amostras de secreção láctea de novilhas no período pré e pós-parto e de vacas com mastite clínica ou subclínica de propriedades comerciais e experimentais, localizadas na região metropolitana de Campinas, Pindamonhangaba, Descalvado e Ribeirão Preto, no estado de São Paulo, Brasil. Também foram utilizadas sete cepas controle de $S$. aureus subsp. aureus (ATCC $^{\circledR} 25923^{\mathrm{TM}}$,

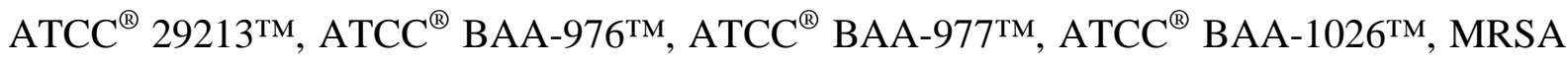
N315 e hetero-VISA Mu-50).

As amostras de secreção láctea foram colhidas entre março de 2009 a agosto de 2011, individualmente em tubos de ensaio esterilizados, previamente identificados com o número do animal e o quarto mamário, conforme procedimentos recomendados por National Mastitis Council (HARMON et al., 1990). Antes da colheita, os animais foram submetidos ao teste de Tamis, para identificação da mastite clínica e ao teste do CMT, para o diagnóstico da mastite subclínica.

Staphylococcus spp. foram isolados e identificados no Laboratório de Qualidade do Leite do Instituto de Zootecnia - CAPTA Bovinos de Leite, Nova Odessa - SP, sob a supervisão da Pesquisadora Dra. Juliana Rodrigues Pozzi Arcaro. A identificação das espécies foi feita por provas bioquímicas (BANNERMAN; PEACOCK, 2007; KLOOS; BANNERMAN, 1999; KLOSS; SCHLEIFER, 1975).

\subsection{Caracterização dos isolados resistentes}

A caracterização de Staphylococcus spp. resistentes foi realizada por método de difusão em disco em ágar Müeller-Hinton (BD- Becton Dicknson Microbiology Sistems and Company Sparks, MD21152 USA), de acordo com os padrões do Clinical Laboratory Standards Institute, CLSI [2008 (veterinário) e 2013]. Os seguintes antimicrobianos foram avaliados: ampicilina $(10 \mu \mathrm{g})$, cefalotina $(30 \mu \mathrm{g})$, ceftiofur $(30 \mu \mathrm{g})$, ciprofloxacina $(5 \mu \mathrm{g})$, clindamicina $(2 \mu \mathrm{g})$, enrofloxacina $(5 \mu \mathrm{g})$, eritromicina $(15 \mu \mathrm{g})$ estreptomicina $(10 \mu \mathrm{g})$, florfenicol $(30 \mu \mathrm{g})$, gentamicina $(10 \mu \mathrm{g})$, kanamicina $(30 \mu \mathrm{g})$, linezolida $(30 \mu \mathrm{g})$, neomicina $(30 \mu \mathrm{g})$, oxacilina $(1$ $\mu \mathrm{g})$, penicilina G (10 UI), sulfametoxazol/trimetoprim $(23.75 / 1.25 \mathrm{mg})$, tetraciclina (30 $\mu \mathrm{g})$, 
vancomicina $(30 \mu \mathrm{g})$ (Oxoid, Basingstok Hants, UK). Para fins de controle de qualidade, foi utilizada a cepa $S$. aureus $\mathrm{ATCC}^{\circledR} 25923^{\mathrm{TM}}$.

\subsection{Confirmação das espécies de Staphylococcus spp.}

A confirmação das espécies bacterianas foi feita pela técnica de MALDI-TOF (Matrixassisted laser desorption ionization time-of-flight), utilizando o aparelho MALDI Biotyper (Bruker Daltonik) e o software MALDI Biotyper OC versão 3.1.66, no Laboratório Fleury, São Paulo - SP.

\subsection{Preparação da solução estoque de nisina}

Nisina (de Lactococcus lactis) 2,5\% (balance sodium chloride and denatured milk solids) foi obtida da Sigma-Aldrich (Sigma-Aldrich, St Louis, MO, USA). A solução estoque de nisina foi preparada em $\mathrm{HCl} 0,02 \mathrm{~N}$ ( $\mathrm{pH} 2,0)$, na concentração de $1 \mathrm{mg} / \mathrm{mL}$, sendo descontaminada por filtração $(0,45 \mu \mathrm{m}$, Millipore, Carring Wohill, Co. Cork, Ireland) e estocada em freezer $-10{ }^{\circ} \mathrm{C}$ por um mês (STEVENS et al., 1991).

\subsection{Preparação de bicelas de lipídeos sintéticos catiônicos}

Brometo de dioctadecildimetilamônio 99,9\% puro foi obtido da Sigma-Aldrich. Nanofragmentos de bicamada (bicelas) de DDA foram preparados por sonicação com macrotip de titânio (25\% de amplitude, por 20 minutos a temperatura ambiente) (Sonics Vibra Cell - Sonics \& Materials, VC x 500, Newtown, CT, USA) em Tampão IGP (Isotonic Glucose Phosphate, $1 \mathrm{mM}$ de fosfato de potássio, $287 \mathrm{mM}$ de glicose, $\mathrm{pH}$ 7,0) na concentração final de $2.0 \mathrm{mM}$ de DDA. A dispersão foi centrifugada a 10621 x g por 1 hora a $4{ }^{\circ} \mathrm{C}$ (Eppendorf 5804R) para remoção de resíduos de titânio, sendo descontaminada por filtração $\left(0,45 \mu \mathrm{m}\right.$, Millipore) e conservado a $4{ }^{\circ} \mathrm{C}$ em geladeira por uma semana (LINCOPAN; CARMONA-RIBEIRO, 2006; SCHALES; SCHALES, 1941).

\subsection{Determinação da Concentração Bactericida Mínima (CBM) da nisina e DDA}

A determinação da Concentração Bactericida Mínima foi feita seguindo as normas padronizadas pela CLSI (2013), com algumas modificações. As colônias bacterianas foram inoculadas em tampão IGP e incubadas a $37{ }^{\circ} \mathrm{C}$ até atingir turbidez padrão de escala 0,5 de 
McFarland. As diluições foram feitas em tampão IGP, nas concentrações iniciais para nisina $200 \mu \mathrm{g} / \mathrm{mL}$ e para DDA $64 \mu \mathrm{g} / \mathrm{mL}$, e em seguida foram feitas dupla diluições. Em seguida, adicionou-se uma alíquota de $100 \mu \mathrm{L}$ das diluições nos poços de placas de microtitulação de poliestireno estéril com 96 poços em fundo chato. Logo após, adicionou-se $5 \mu \mathrm{L}$ do inóculo e incubou-se em estufa bacteriológica a $37{ }^{\circ} \mathrm{C}$ por 24 horas. Para fins de controle positivo, adicinou-se em um poço tampão IGP e o inóculo e para controle negativo, apenas tampão IGP.

Após a incubação, efetuou-se o método de plaqueamento das concentrações avaliadas. Uma alíquota de $5 \mu \mathrm{L}$ de cada poço foi adicionada em placas de Ágar Müeller-Hinton (BD) e incubadas por mais 24 horas. A leitura da CBM foi feita observando o crescimento de UFC nas diferentes diluições de nisina e DDA.

\subsection{Avaliação "in vitro" da interação entre nisina e DDA}

A avaliação da combinação in vitro da nisina e do DDA (complexo NS/DDA) foi feita pelo método de checkerboard, conforme Anonymous (1992), com algumas modificações.

Colônias bacterianas foram inoculadas em tampão IGP e incubadas a $37{ }^{\circ} \mathrm{C}$ até atingir turbidez padrão de escala 0,5 de McFarland. Concentrações de nisina e DDA preparadas em tampão IGP, foram distribuídas numa placa de microtitulação de poliestireno estéril com 96 poços em fundo chato como um tabuleiro de xadrez (Figura 5). Na vertical, adicionaram-se $50 \mu \mathrm{L}$ em cada poço diferentes concentrações diluídas da nisina de forma decrescente (poços A - G). Na horizontal, adicionou-se $50 \mu \mathrm{L}$ em cada poço uma diferente concentração diluída do DDA, da esquerda para a direita de forma crescente (poços 2 - 9), totalizando $100 \mu \mathrm{L}$ em cada poço. Depois de uma hora, foi adicionado $5 \mu \mathrm{L}$ do inóculo. As placas foram incubadas em estufa bacteriológica a $37{ }^{\circ} \mathrm{C}$ por 24 horas. Para fins de controle positivo, foi adicionado em um poço tampão IGP e o inóculo e para controle negativo, apenas tampão IGP. Após a incubação, uma alíquota de $5 \mu \mathrm{L}$ de cada poço foi adicionada em placas de Ágar MüellerHinton (BD) e incubou-se por mais 24 horas. A leitura foi feita observando o crescimento das colônias nas diferentes combinações de nisina e DDA. 
Figura 5 - Representação esquemática da metodologia de checkerboard para avaliação da interação entre as moléculas de nisina e DDA.

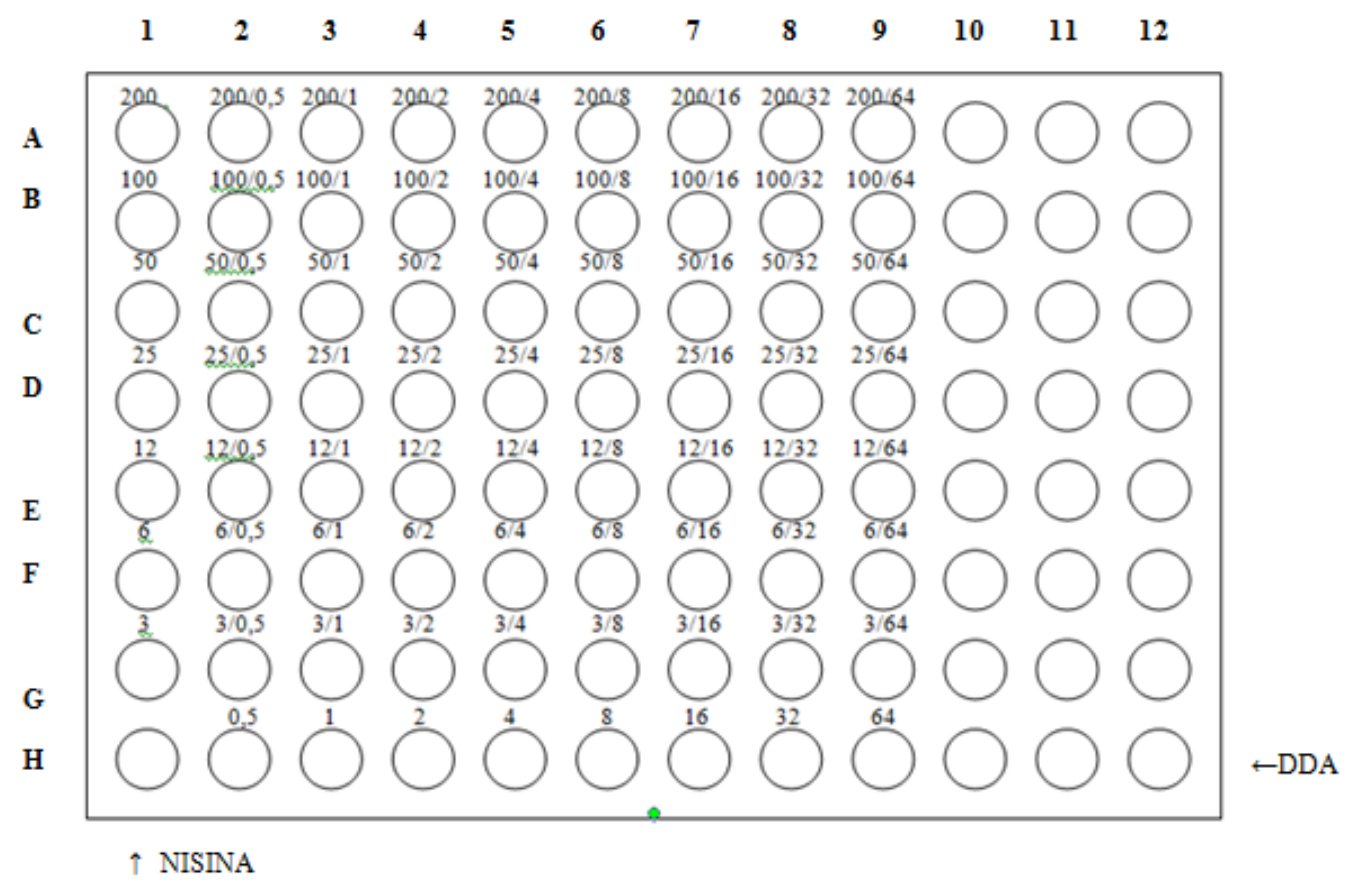

A avaliação da interação entre a nisina e o DDA foi determinada através do cálculo da Fractionary Bactericidal Concentration (FBC), onde é feito o cálculo da somatória dos índices de concentração bactericida fracional A e B ( FBC) (FERNANDEZ-CUENCA et al., 2003; HALL; MIDDLETON; WESTMACOTT, 1983), onde:

$\operatorname{FBC}(\mathrm{A}$ ou $\mathrm{B})=\underline{\mathrm{CBM} \text { do } \mathrm{A}(\text { ou B }) \text { em combinação }}$

CBM do A (ou B) sozinho

Sendo que, $\Sigma F B C \leq 0,5=$ efeito sinérgico.

$\Sigma$ FBC entre $>0,5-\leq 1,0=$ efeito parcialmente sinérgico

$\Sigma \mathrm{FBC} \geq 4,0=$ antagonismo

$\Sigma$ FBC entre $1,0-4,0=$ indiferente.

O sinergismo corresponde a uma interação positiva, onde o efeito combinado das drogas é significativamente maior que seus efeitos independentes. Um efeito parcialmente sinérgico é quando o efeito combinado produzido é igual à soma dos seus efeitos independentes. $\mathrm{O}$ antagonismo corresponde a uma interação negativa, no qual a combinação dos agentes antimicrobianos é significativamente menor que os seus efeitos independentes. Quando não há interação significativa entre os fármacos, o resultado é considerado indiferente (LORIAN, 2005). 


\section{8 "Time-kill" (curva de morte em função do tempo)}

A curva de morte em função do tempo foi realizada conforme técnica proposta por Giamarellos-Bourboulis, Grecka e Giamarello (1997) com a nisina e o DDA com as concentrações da CBM e do teste de sinergismo (checkerboard).

Colônias bacterianas da cepa $S$. aureus MRSA N315 foram inoculadas em tampão IGP e incubadas a $37^{\circ} \mathrm{C}$ até atingir turbidez padrão de escala 0,5 de McFarland. Mil microlitros das concentrações da nisina e DDA foram preparadas em microtubos e logo após, adicionados $50 \mu \mathrm{L}$ do inóculo inicial de $1,5 \times 10^{8} \mathrm{UFC} / \mathrm{mL}$ e incubados em estufa bacteriológica a $37^{\circ} \mathrm{C}$, nos tempos $0,1,2,4,8,12$ e 24 horas. Também foi preparado um tubo apenas com inóculo para fins de controle positivo. Em cada tempo, foi aliquotado $10 \mu \mathrm{L}$ de cada uma das concentrações e do controle e feita uma diluição seriada de 1:10, 1:100, 1:1000, 1:10000 e 1:100000, em tampão IGP. Em seguida, foi aliquotado $50 \mu \mathrm{L}$ de cada diluição e as colônias foram semeadas com auxílio da alça de Drigalski em Ágar Müeller-Hinton (BD) e incubadas a $37{ }^{\circ} \mathrm{C}$. A leitura foi feita através da contagem direta das colônias presentes nas placas de cada diluição, no seu respectivo tempo e depois, o cálculo foi feito para a obtenção do número de UFC viáveis/ml.

Os critérios de classificação foram estabelecidos conforme proposto por Lorian (2005) com algumas modificações. Efeito bactericida foi definido como uma redução de $\geq 3 \log _{10}$ UFC/mL, após 24 horas de incubação em comparação com o tamanho do inóculo inicial. A sinergia e o antagonismo foram definidos como um aumento ou diminuição, respectivamente, de $\geq 2 \log _{10} \mathrm{UFC} / \mathrm{mL}$ em atividade antibacteriana produzido pela combinação em comparação com um agente sozinho, enquanto que a mudança de $2 \log _{10} \mathrm{UFC} / \mathrm{mL}$ foi considerada indiferente.

\subsection{Avaliação da viabilidade celular por microscopia de fluorescência}

Para determinação da viabilidade celular utilizou-se o kit LIVE/DEAD ${ }^{\circledR}$ BacLight $^{\mathrm{TM}}$ Bacterial Viability Kits (Molecular Probes, Inc., Invitrogen) seguido de observação em microscópio de fluorescência.

As colônias bacterianas da cepa S. aureus MRSA N315 foram inoculadas em tampão IGP e centrifugadas duas vezes por 5 minutos a 1844 x g para lavagem e remoção de possíveis resíduos de meio de cultura. Logo após, ressuspendeu-se em tampão IGP e incubouse a $37{ }^{\circ} \mathrm{C}$ até atingir turbidez padrão de escala 0,5 de McFarland. Concentrações de nisina e 
DDA, preparadas em tampão IGP, foram aliquotadas em microtubos e adicionado o inóculo bacteriano. Volumes iguais de ambos os marcadores foram misturados e a cada $1 \mathrm{~mL}$ de amostra adicionou-se $3 \mu \mathrm{L}$ da mistura, e incubados por 20 minutos no escuro. Um volume de $2 \mathrm{~mL}$ foi analisado em microscópio de fluorescência DMI6000B/AF6000 (Leica) acoplado a um sistema de câmera digital (DFC 365 FX). A viabilidade das bactérias foi observada no sistema de microscopia com a ajuda do programa Leica AF6000 e do programa Image J.

\subsection{Caracterização físico-química das partículas de nisina e DDA por "Light Scattering" $e$ Potencial Zeta}

As distribuições de tamanho e carga superficial foram determinadas por meio do equipamento ZetaPals-Zeta Potential Analyzer (Brookhaven Instruments Corporation, Holtsville, NY), equipado com um laser de $570 \mathrm{~nm}$ e espalhamento de luz dinâmica a $90^{\circ}$. Os compostos e a cepa foram preparados em tampão IGP em diferentes concentrações e diferentes combinações de nisina, DDA e a cepa $S$. aureus MRSA N315 (turbidez padrão de escala 0,5 de McFarland), todas com volume final de $2 \mathrm{~mL}$. As combinações utilizadas nas condições de sinergismo foram obtidas previamente pelo método checkerboard. As leituras foram realizadas após uma hora de interação e incubação. 


\section{RESULTADOS}

\subsection{Perfil de resistência antimicrobiana e a atividade "in vitro" da nisina e DDA}

Através do método de difusão em disco, foi observado que do total de isolados de Staphylococcus spp. (n=269), 156 (58\%) foram resistentes à pelo menos uma droga avaliada, sendo que 95 e 61 isolados foram classificados, através de provas bioquímicas, como $S$. aureus e CoNS, respectivamente. Destes 156 isolados resistentes, 30 cepas foram selecionadas para as posteriores análises, de diferentes propriedades e animais, de acordo com o perfil de resistência e a espécie.

Em seguida, essas cepas foram submetidas à técnica de MALDI-TOF para confirmação das espécies, onde 14 foram confirmadas como $S$. aureus, duas como S. capitis, nove $S$. chromogenes, uma S. epidermidis, duas Staphylococcus haemolyticus, uma S. sciuri e uma como Staphylococcus warneri. Na Tabela 2 estão expostos os resultados do antibiograma das cepas escolhidas, separadas por espécie, conforme resultados do MALDI-TOF. Nota-se que a maior parte apresentou resistência principalmente ao grupo dos beta-lactâmicos (ampicilina e penicilina). Ainda, houve resistência aos aminoglicosídeos, à tetraciclina, ao florfenicol, macrolídeos e quinolonas. Todos os isolados apresentaram sensibilidade à cefalotina, ceftiofur e vancomicina.

Em seguida, as 30 cepas escolhidas, assim como as sete cepas controle de $S$. aureus subsp. aureus $\left(\mathrm{ATCC}^{\circledR}\right)$, foram submetidas ao teste para a determinação da CBM da nisina e do DDA, e também à avaliação da interação in vitro do complexo NS/DDA, em tampão IGP. Os resultados estão apresentados na Tabela 2. A $\mathrm{CBM}_{50}$ da nisina foi $50 \mu \mathrm{g} / \mathrm{mL}$, enquanto que do DDA foi $4 \mu \mathrm{g} / \mathrm{mL}$. Os resultados da técnica de checkerboard confirmaram o efeito in vitro da associação entre nisina e DDA (complexo NS/DDA) que resultou numa redução da $\mathrm{CBM}_{50}$ para $3 / 2 \mu \mathrm{g} / \mathrm{mL}$, e apresentou efeito sinérgico para 2,7\% (1/37) das cepas, parcialmente sinérgico para $51,4 \%$ (19/37) e indiferente para 45,9\% dos isolados, conforme o cálculo da FBC.

Observou-se também que para apenas duas cepas, 7N (S. sciuri) e ATCC ${ }^{\circledR}$ BAA-977TM (S. aureus) houve valores de CBM mais elevados de DDA $(32 \mu \mathrm{g} / \mathrm{mL})$. Além disso, quando associado à nisina, a CBM do DDA diminuiu para $16 \mu \mathrm{g} / \mathrm{mL}$. 
Tabela 2 - Resultados do perfil de resistência antimicrobiana por difusão em disco, valores da CBM da nisina e DDA e dos resultados do checkerboard do complexo NS/DDA de cepas de Staphylococcus spp. isoladas de mastite bovina e de cepas S. aureus ATCC ${ }^{\circledR}$.

\begin{tabular}{|c|c|c|c|c|c|c|c|c|c|c|}
\hline \multirow[b]{2}{*}{ Número da cepa } & \multirow[b]{2}{*}{ Propriedade } & \multirow[b]{2}{*}{ Espécie } & \multirow[b]{2}{*}{ Perfil de Resistência } & \multicolumn{3}{|c|}{$\mathrm{CBM}(\mu \mathrm{g} / \mathrm{mL})$} & \multicolumn{4}{|l|}{ FBC } \\
\hline & & & & NS & DDA & NS/DDA & NS & DDA & $\Sigma \mathrm{FBC}$ & Int. \\
\hline $45 \mathrm{~T}$ & $\mathrm{~A}$ & S. aureus & Ery, Ffc, Kan, Lzd, Neo & 50 & 4 & $3 / 2$ & 0,06 & 0,50 & 0,56 & PS \\
\hline $558 \mathrm{~T}$ & $\mathrm{~B}$ & S. aureus & Ffc, Lzd & 50 & 8 & $3 / 2$ & 0,06 & 0,25 & 0,31 & $S$ \\
\hline $731 \mathrm{~T}$ & $\mathrm{~B}$ & S. aureus & Amp, Pen & 50 & 4 & $3 / 4$ & 0,06 & 1,00 & 1,06 & I \\
\hline $906 \mathrm{~T}$ & $\mathrm{C}$ & S. aureus & Amp, Pen & 50 & 4 & $3 / 4$ & 0,06 & 1,00 & 1,06 & I \\
\hline $969 \mathrm{~T}$ & $\mathrm{C}$ & S. aureus & Amp, Cli, Ery, Pen, Tet & 50 & 4 & $3 / 4$ & 0,06 & 1,00 & 1,06 & I \\
\hline $1025 \mathrm{~T}$ & $\mathrm{D}$ & S. aureus & Amp, Pen, Tet & 50 & 4 & $3 / 4$ & 0,06 & 1,00 & 1,06 & $\mathrm{I}$ \\
\hline $1027 \mathrm{~T}$ & $\mathrm{D}$ & S. aureus & Amp, Pen, Tet, Str & 100 & 4 & $3 / 2$ & 0,03 & 0,50 & 0,53 & PS \\
\hline $1037 \mathrm{~T}$ & $\mathrm{D}$ & S. aureus & Amp, Pen, Tet, Str & 50 & 2 & $3 / 2$ & 0,06 & 1,00 & 1,06 & I \\
\hline $1079 \mathrm{~T}$ & $\mathrm{D}$ & S. aureus & Amp, Pen, Tet, Str & 50 & 4 & $3 / 4$ & 0,06 & 0,50 & 0,56 & PS \\
\hline $1705 \mathrm{~T}$ & $\mathrm{H}$ & S. aureus & Cip, Cli, Kan, Lzd, Neo, Sxt, & 50 & 8 & $3 / 4$ & 0,06 & 0,50 & 0,56 & PS \\
\hline $1808 \mathrm{~T}$ & $\mathrm{E}$ & S. aureus & Amp, Pen, Str & 50 & 2 & $3 / 2$ & 0,06 & 1,00 & 1,06 & I \\
\hline $1849 \mathrm{~T}$ & $\mathrm{E}$ & S. aureus & Amp, Cip, Cli, Ery, Eno, Pen & 50 & 2 & $3 / 2$ & 0,06 & 1,00 & 1,06 & I \\
\hline $1960 \mathrm{~T}$ & $\mathrm{E}$ & S. aureus & Amp, Eno, Pen & 50 & 2 & $12 / 1$ & 0,24 & 0,50 & 0,74 & PS \\
\hline $111 \mathrm{~N}$ & $\mathrm{~F}$ & S. aureus & Amp, Pen & 50 & 4 & $6 / 2$ & 0,12 & 0,50 & 0,62 & PS \\
\hline $180 \mathrm{~N}$ & G & S. capitis & Amp, Pen & 50 & 4 & $3 / 2$ & 0,06 & 0,50 & 0,56 & PS \\
\hline $565 \mathrm{~T}$ & $\mathrm{~B}$ & S. capitis & Amp, Pen, Tet & 50 & 4 & $3 / 2$ & 0,06 & 0,50 & 0,56 & PS \\
\hline $89 \mathrm{~N}$ & $\mathrm{~F}$ & S. chromogenes & Amp, Pen, Str & 50 & 2 & $3 / 2$ & 0,06 & 1,00 & 1,06 & I \\
\hline $90 \mathrm{~N}$ & $\mathrm{~F}$ & S. chromogenes & Amp, Gen, Pen, Str & 50 & 4 & $3 / 4$ & 0,06 & 1,00 & 1,06 & I \\
\hline $118 \mathrm{~N}$ & G & S. chromogenes & Amp, Ffc, Pen, Tet & 50 & 4 & $3 / 2$ & 0,06 & 0,50 & 0,56 & PS \\
\hline $120 \mathrm{~T}$ & A & S. chromogenes & Cli, Ffc, Lzd, Neo, Str, Tet & 50 & 2 & $3 / 2$ & 0,06 & 1,00 & 1,06 & $\mathrm{I}$ \\
\hline $121 N$ & G & S. chromogenes & Amp, Ffc, Pen, Str, Tet & 50 & 4 & $3 / 4$ & 0,06 & 1,00 & 1,06 & I \\
\hline $148 \mathrm{~N}$ & $\mathrm{G}$ & S. chromogenes & Amp, Ffc, Pen, Tet & 50 & 2 & $3 / 2$ & 0,06 & 1,00 & 1,06 & I \\
\hline $158 \mathrm{~N}$ & G & S. chromogenes & Amp, Ffc, Pen, Tet & 50 & 4 & $3 / 4$ & 0,06 & 0,50 & 0,56 & PS \\
\hline $498 \mathrm{~T}$ & G & S. chromogenes & Amp, Ffc, Pen & 50 & 4 & $3 / 4$ & 0,06 & 1,00 & 1,06 & I \\
\hline $1501 \mathrm{~T}$ & G & S. chromogenes & Oxa, Sxt & 50 & 4 & $3 / 2$ & 0,06 & 0,50 & 0,56 & PS \\
\hline 1043TE & $\mathrm{A}$ & S. epidermidis & Amp, Kan, Neo, Pen, Tet & 50 & 4 & $3 / 2$ & 0,06 & 0,50 & 0,56 & PS \\
\hline
\end{tabular}


Tabela 3 (Continuação) - Resultados do perfil de resistência antimicrobiana por difusão em disco, valores da CBM da nisina e DDA e dos resultados do checkerboard do complexo NS/DDA de cepas de Staphylococcus spp. isoladas de mastite bovina e de cepas S. aureus ATCC ${ }^{\circledR}$.

\begin{tabular}{|c|c|c|c|c|c|c|c|c|c|c|}
\hline \multirow[b]{2}{*}{ Número da cepa } & \multirow[b]{2}{*}{ Propriedade } & \multirow[b]{2}{*}{ Espécie } & \multirow[b]{2}{*}{ Perfil de Resistência } & \multicolumn{3}{|c|}{$\mathrm{CBM}(\mu \mathrm{g} / \mathrm{mL})$} & \multicolumn{4}{|l|}{ FBC } \\
\hline & & & & NS & DDA & NS/DDA & NS & DDA & $\Sigma \mathrm{FBC}$ & Int. \\
\hline $75 \mathrm{~N}$ & A & S. haemolyticus & Amp, Pen & 25 & 4 & $3 / 2$ & 0,12 & 0,50 & 0,62 & PS \\
\hline $133 \mathrm{~N}$ & G & S. haemolyticus & Amp, Flf, Pen & 50 & 8 & $3 / 4$ & 0,06 & 0,50 & 0,56 & PS \\
\hline $7 \mathrm{~N}$ & $\mathrm{~A}$ & S. sciuri & Oxa & 50 & 32 & $6 / 16$ & 0,12 & 0,50 & 0,62 & PS \\
\hline $107 \mathrm{~N}$ & $\mathrm{~F}$ & S. warneri & Amp, Pen & 50 & 4 & $3 / 2$ & 0,06 & 0,50 & 0.56 & PS \\
\hline $\mathrm{ATCC}^{\circledR} 25923^{\mathrm{TM}}$ & - & S. aureus & - & 100 & 4 & $3 / 2$ & 0,03 & 0,5 & 0,53 & PS \\
\hline ATCC $^{\circledR} 29213^{\mathrm{TM}}$ & - & S. aureus & Amp, Pen & 50 & 4 & $3 / 4$ & 0,06 & 1,0 & 1,06 & I \\
\hline ATCC $^{\circledR}$ BAA- $976^{\mathrm{TM}}$ & - & S. aureus & Amp, Fur, Ery, Neo, Oxa, Pen & 100 & 4 & $3 / 2$ & 0,03 & 1,0 & 1,03 & I \\
\hline ATCC $^{\circledR}$ BAA-977тм & - & S. aureus & Amp, Ery, Pen & 100 & 32 & $3 / 16$ & 0,03 & 0,5 & 0,53 & PS \\
\hline ATCC $^{\circledR}$ BAA-1026 ${ }^{\mathrm{TM}}$ & - & S. aureus & Amp, Cf, Fur, Cli, Eno, Ery, Gen, Neo, Oxa, Pen, Sxt & 100 & 4 & $3 / 4$ & 0,03 & 1,0 & 1,03 & I \\
\hline MRSA N315 & - & S. aureus & Amp, Oxa, Pen, Tet & 50 & 4 & $3 / 2$ & 0,06 & 0,5 & 0,56 & PS \\
\hline Hetero-VISA MU-50 & - & S. aureus & Amp, Cf, Cli, Eno, Ery, Fur, Gen, Neo, Oxa, Pen, Tet, Van & 50 & 4 & $3 / 4$ & 0,06 & 1,0 & 1,06 & I \\
\hline
\end{tabular}

Legenda: Int.: Interpretação; Amp: ampicilina; Cf: cefalotina; Fur: ceftiofur; Cip: ciprofloxacina; Cli: clindamicina; Eno: enrofloxacina; Ery: eritromicina; Ffc: florfenicol; Gen: gentamicina; Kan: kanamicina; Lzd: linezolida; Neo: neomicina; Oxa: oxacilina; Pen: penicilina G; Str: estreptomicina; Sxt: sulfametoxazol/trimetoprim; Tet: tetraciclina; CBM: Concentração Bactericida Mínima; FBC: Concentração Bactericida Fracional (FBC = CBM combinação / CBM sozinho); $\Sigma$ FBC- Somatória das FBCs; $\Sigma F B C \leq 0,5=$ efeito sinérgico (S), $\Sigma$ FBC entre $>0,5-\leq 1,0=$ efeito parcialmente sinérgico (PS), $\Sigma F B C \geq 4,0=$ antagonismo $(\mathrm{A}), \Sigma \mathrm{FBC}$ entre $1,0-4,0=$ indiferente $(\mathrm{I})$. 


\subsection{Estudo do "Time-kill"}

Através dos ensaios de curva de morte em função do tempo foi possível determinar a potência in vitro da nisina, DDA e do complexo NS/DDA frente à cepa $S$. aureus MRSA N315, por meio da contagem de bactérias viáveis ao longo do tempo. Os resultados são apresentados na Figura 6, onde é possível observar o efeito bactericida já na primeira hora de interação entre o complexo NS/DDA $3 / 2 \mu \mathrm{g} / \mathrm{mL}$ e a cepa, com uma redução de $\geq 3 \log _{10}$ $\mathrm{UFC} / \mathrm{mL}$, enquanto que a concentração de NS $50 \mu \mathrm{g} / \mathrm{mL}$ atingiu a atividade bactericida após duas horas de interação e do DDA $4 \mu \mathrm{g} / \mathrm{mL}$ após três horas. As concentrações sozinhas de NS $3 \mu \mathrm{g} / \mathrm{mL}$ e DDA $2 \mu \mathrm{g} / \mathrm{mL}$ não apresentaram redução de $\geq 3 \log _{10} \mathrm{UFC} / \mathrm{mL}$ na taxa de crescimento bacteriano após 24 horas de incubação.

Além disso, o estudo de time-kill demonstrou que o complexo NS/DDA 3/2 $\mu \mathrm{g} / \mathrm{mL}$ possui efeito um sinérgico dentro de 24 horas de incubação (aumento de atividade antibacteriana de $\geq 2 \log _{10} \mathrm{UFC} / \mathrm{mL}$ produzido pelo complexo em comparação com a NS 3 $\mu \mathrm{g} / \mathrm{mL}$ sozinha).

Figura 6 - Curva de morte em função do tempo para a cepa $S$. aureus MRSA N315. As bactérias foram incubadas em tampão IGP (controle); tampão IGP e concentrações da CBM da nisina, DDA e do complexo NS/DDA. Os resultados estão expressos em $\log _{10} \mathrm{UFC} / \mathrm{mL}$.

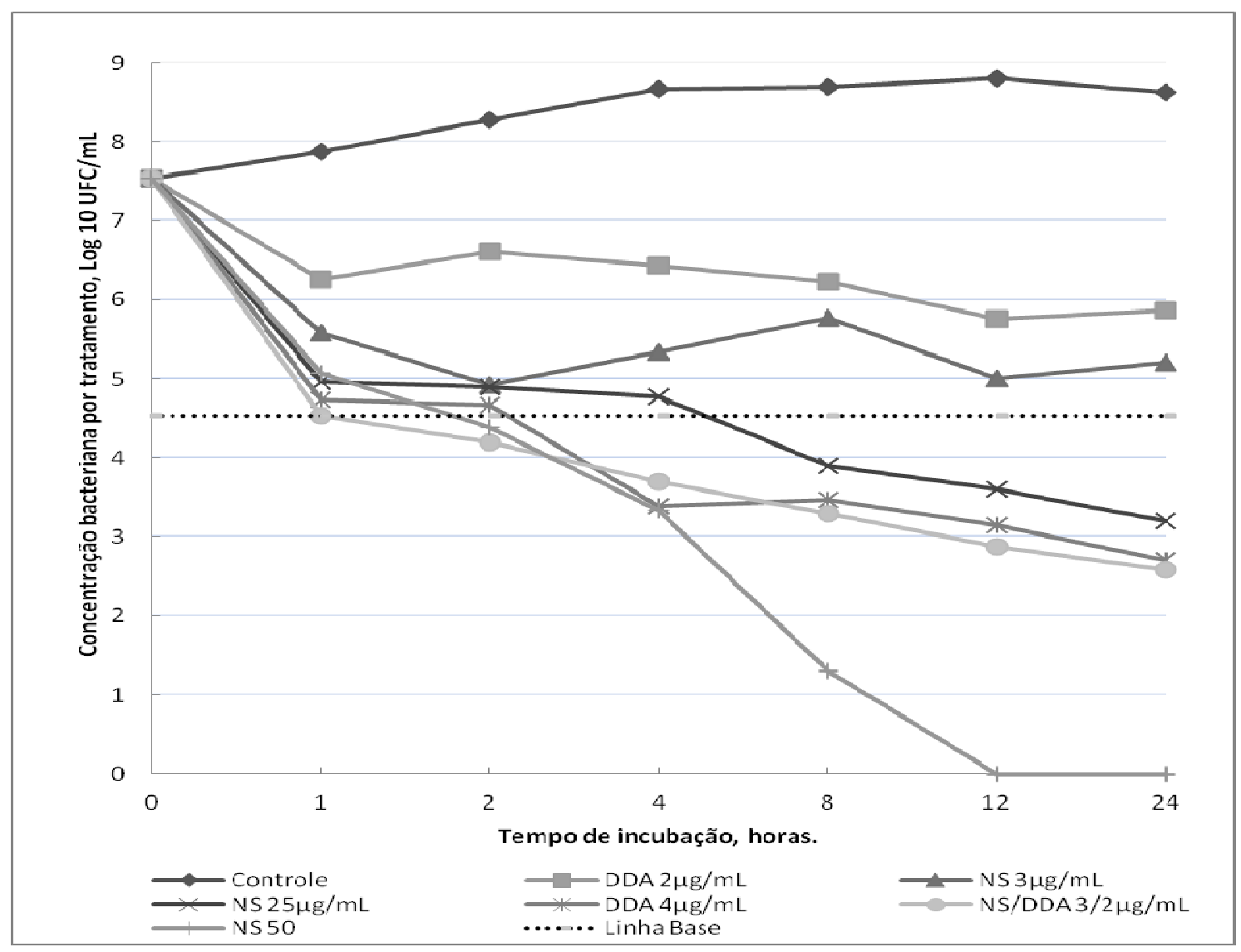




\subsection{Avaliação da viabilidade celular por microscopia de fluorescência}

Através da microscopia de fluorescência e dos marcadores SYTO 9, que penetra na membrana intacta ou danificada de células vivas, e emite fluorescência verde, e o marcador iodeto de propídeo, que cora apenas as células que apresentam algum dano em sua membrana, emitindo fluorescência vermelha (BOULOS et al., 1999), foi possível observar o efeito do complexo NS/DDA na viabilidade celular da cepa S. aureus MRSA N315 (Figura 7). Nota-se que após seis horas de interação com o complexo NS/DDA, quase que a totalidade das células bacterianas encontra-se coradas de vermelho, o que sugere alteração da parede, ocasionando efeito bactericida.

Figura 7 - Imagem de microscopia de fluorescência (x63) da cepa de S. aureus MRSA N315 tratados com complexos de NS/DDA, marcadas com SYTO 9 (verde) e iodeto de propídeo (vermelho). (A, C) - Tempo zero, com e sem filtro verde, respectivamente; (B, D) - Após seis horas de interação, com e sem filtro verde, respectivamente. Barras de escala $-5.00 \mu \mathrm{m}$.
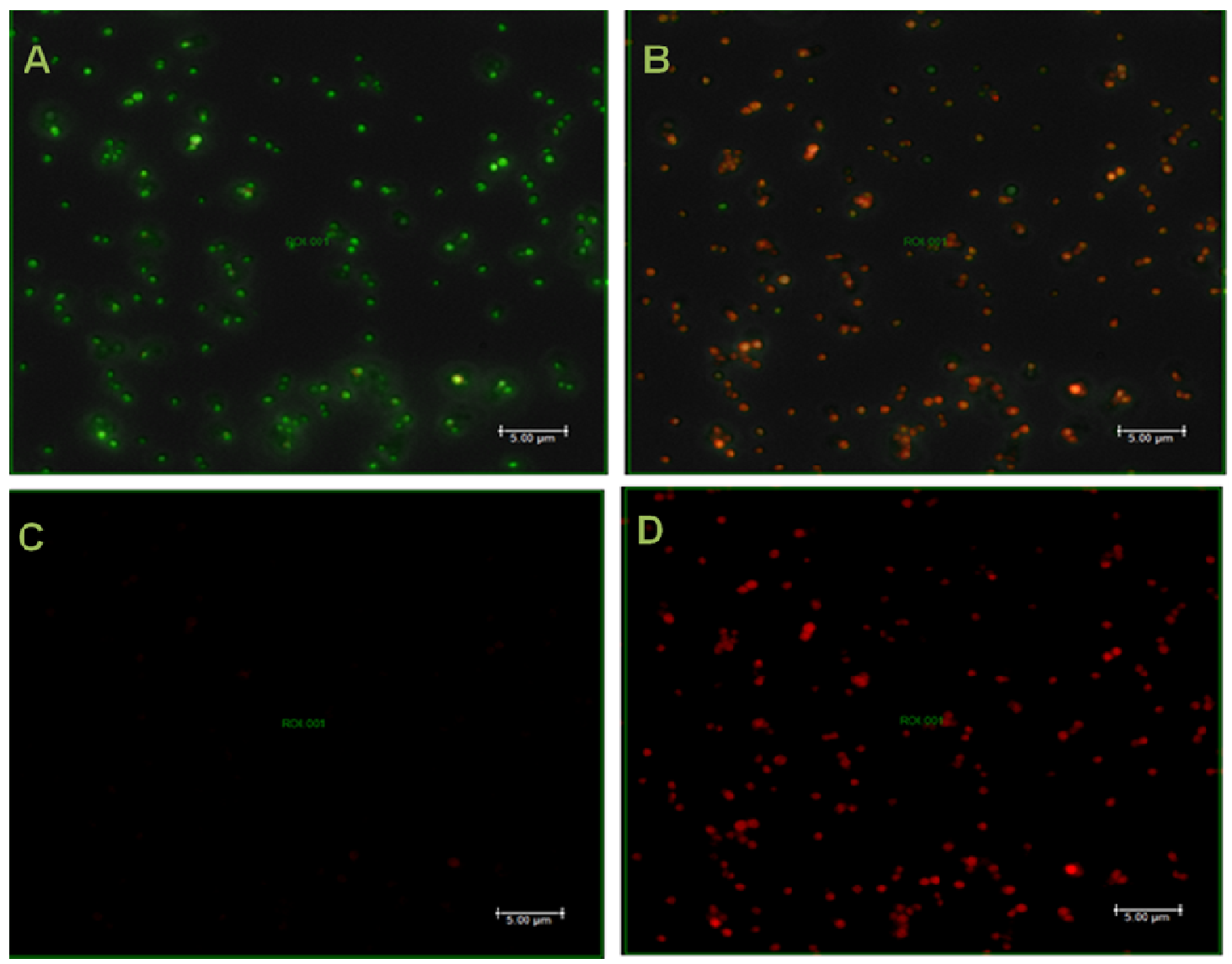
5.4 “Light Scattering” e Potencial Zeta das formulações e a sua interação com $\underline{\text { S. aureus }}$ MRSA N315

Os resultados das análises de Light Scattering e do potencial Zeta da molécula de nisina, DDA, cepa $S$. aureus MRSA N315 e de diferentes associações entre eles, estão apresentados na Tabela 3. Para a leitura do complexo NS/DDA, foi necessário prepará-lo em uma concentração dez vezes maior $(30 / 20 \mu \mathrm{g} / \mathrm{mL})$ que a concentração da $\mathrm{CBM}_{50}(3 / 2 \mu \mathrm{g} / \mathrm{mL})$ devido à sensibilidade do equipamento. Observa-se que a cepa bacteriana possui uma carga negativa $(-27,32 \mathrm{mV})$ e as moléculas de nisina e DDA possuem carga positiva $(0,62$ e 19,46 $\mathrm{mV}$, respectivamente).

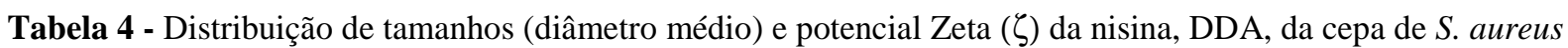
MRSA N315 e diferentes associações entre eles, em tampão IGP.

\begin{tabular}{lcccccc}
\hline Partículas & $\mathrm{D}_{\mathrm{z}}(\mathrm{nm})$ & $\mathrm{DP}$ & Polidispersão & DP & $\zeta(\mathrm{mV})$ & $\mathrm{DP}$ \\
\hline S. aureus MRSA N315 & 1073,7 & 29,5 & 0,219 & 0,038 & $-27,32$ & 1,37 \\
DDA $2 \mathrm{mM}$ & 069,4 & 0,7 & 0,216 & 0,007 & 19,46 & 1,20 \\
NS 300 $\mu \mathrm{g} / \mathrm{mL}$ & 187,9 & 14,5 & 0,630 & 0,055 & 0,62 & 0,62 \\
NS/DDA 30/20 $\mu \mathrm{g} / \mathrm{mL}$ & 148,5 & 22,5 & 0,461 & 0,021 & 8,84 & 4,83 \\
NS/DDA 3/2 $\mu \mathrm{g} / \mathrm{mL}+$ S. aureus MRSA N315 & 556,9 & 14,3 & 0,380 & 0,013 & $-8,12$ & 1,22 \\
NS/DDA 30/20 $\mu \mathrm{g} / \mathrm{mL}+$ S. aureus MRSA N315 & 462,8 & 18,8 & 0,434 & 0,017 & 15,28 & 0,40 \\
NS/DDA 300/200 $\mu \mathrm{g} / \mathrm{mL}+$ S. aureus MRSA & 270,7 & 19,5 & 0,416 & 0,007 & 33,56 & 0,97 \\
N315 & & & &
\end{tabular}

Legenda: $\mathrm{D}_{\mathrm{z}^{-}}$diâmetro médio em nanômetros $(\mathrm{nm})$; $\zeta$ - potencial Zeta em milivolts (mV); DP- desvio padrão.

Na condição estudada, em baixa força iônica (tampão IGP), a interação das moléculas resultou em um complexo catiônico, o que contribui para a adesão à superfície bacteriana negativa e favorece a ação bactericida do complexo. Isso fica evidente quando se analisa a interação do complexo e a bactéria, após uma hora de incubação, nas concentrações de 3/2 $\mu \mathrm{g} / \mathrm{mL}, 30 / 20 \mu \mathrm{g} / \mathrm{mL}$ e $300 / 200 \mu \mathrm{g} / \mathrm{mL}$, onde foi possível observar uma mudança na carga superficial, de negativa para positiva e uma diminuição do tamanho das partículas, que possivelmente corresponde à destruição da bactéria (Figura 8). 
Figura 8 - Distribuição de tamanhos (diâmetro médio $-\mathrm{D}_{\mathrm{z}}$ ) em nanômetro $(\mathrm{nm})$ e potencial Zeta $(\zeta)$ em milivolts (mV). A- Cepa S. aureus MRSA N315; B- DDA $2 \mathrm{mM}$; C- nisina $300 \mu \mathrm{g} / \mathrm{mL}$; D- Complexo NS/DDA 30/20 $\mu \mathrm{g} / \mathrm{mL}$. As setas indicam que as escalas estão em (A,D) $5000 \mathrm{~nm}$ e (B,C) $500 \mathrm{~nm}$.

A

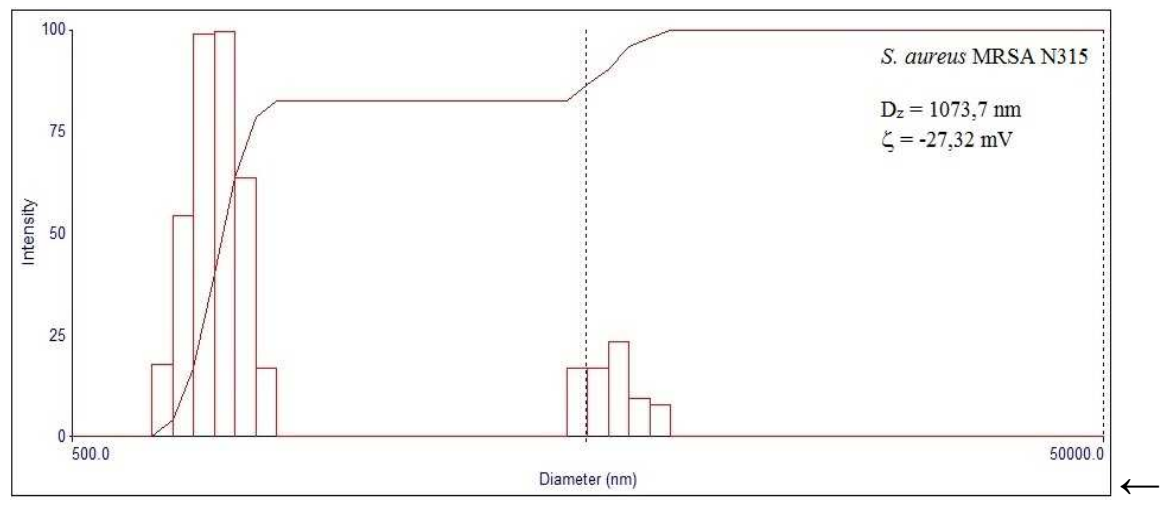

B

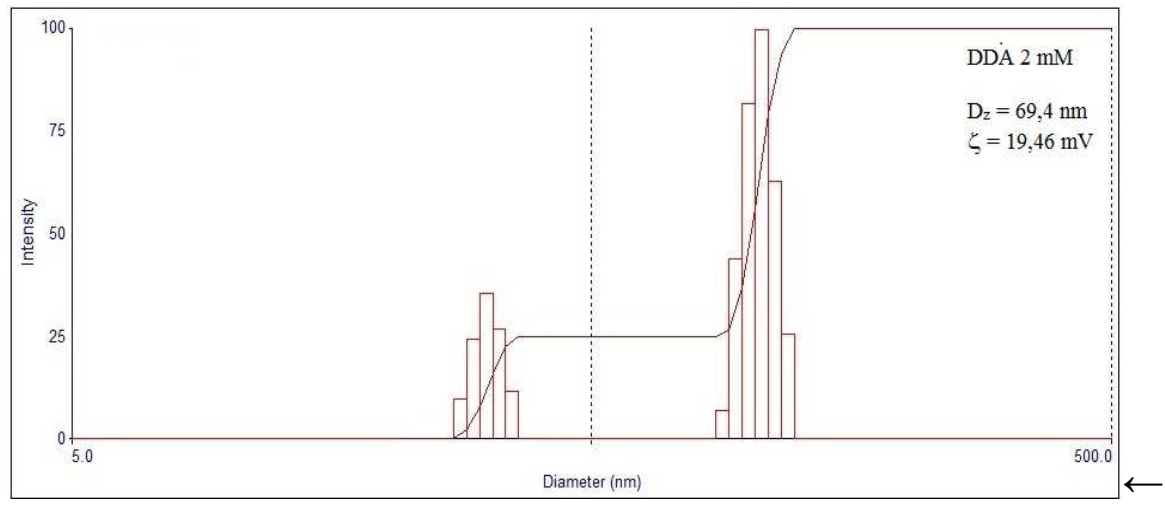

C

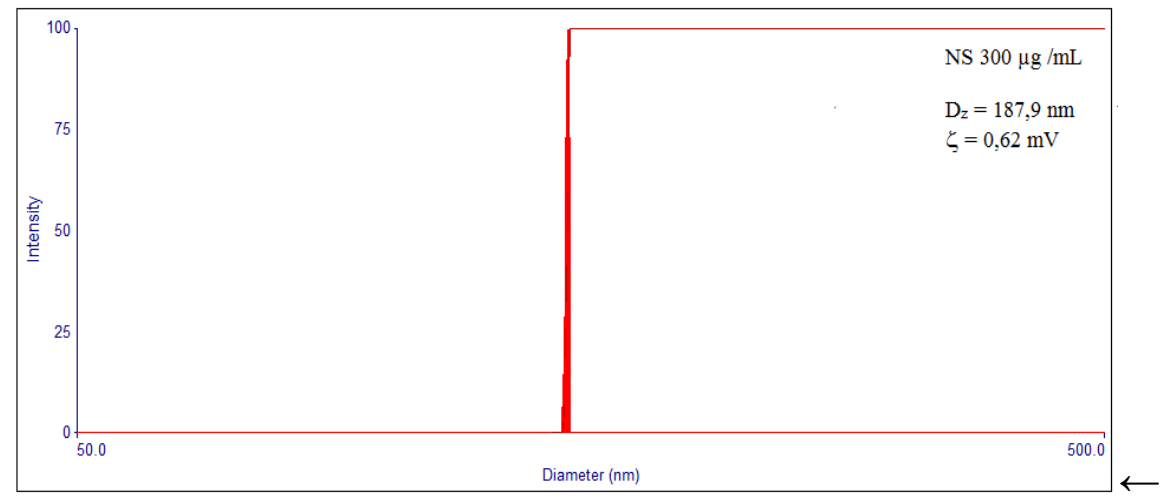

D

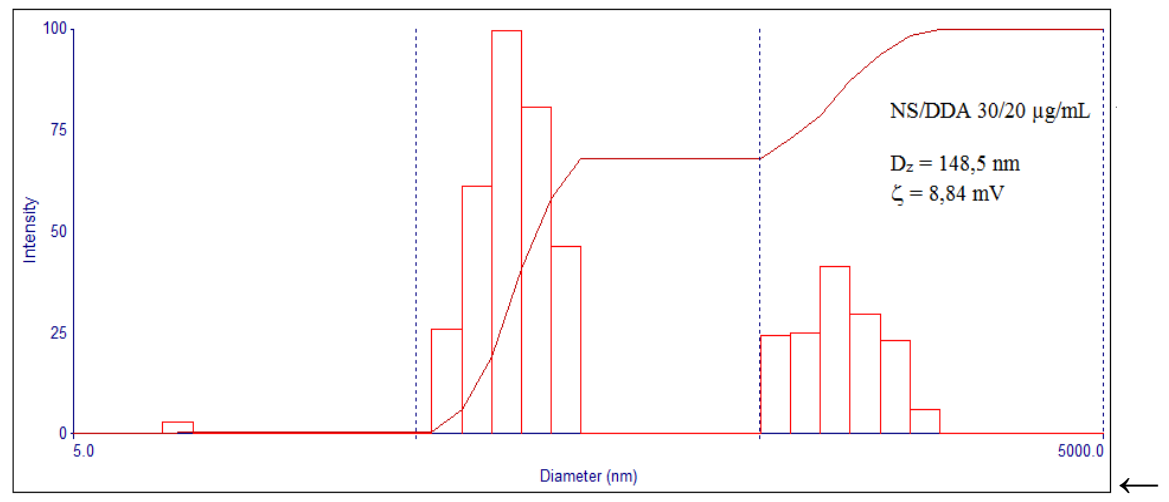


Figura 8 (Continuação) - Distribuição de tamanhos (diâmetro médio - $\mathrm{D}_{\mathrm{z}}$ ) em nanômetro (nm) e potencial Zeta ( $\zeta$ ) em milivolts (mV). E- Interação entre o complexo NS/DDA $3 / 2 \mu \mathrm{g} / \mathrm{mL}$ e a cepa de $S$. aureus MRSA N315; F- Interação entre o complexo NS/DDA 30/20 $\mu \mathrm{g} / \mathrm{mL}$ e a cepa de $S$. aureus MRSA N315; G- Interação entre o complexo NS/DDA 300/200 $\mu \mathrm{g} / \mathrm{mL}$ e a cepa de $S$. aureus MRSA N315. As setas indicam que as escalas estão em $5000 \mathrm{~nm}$.

E

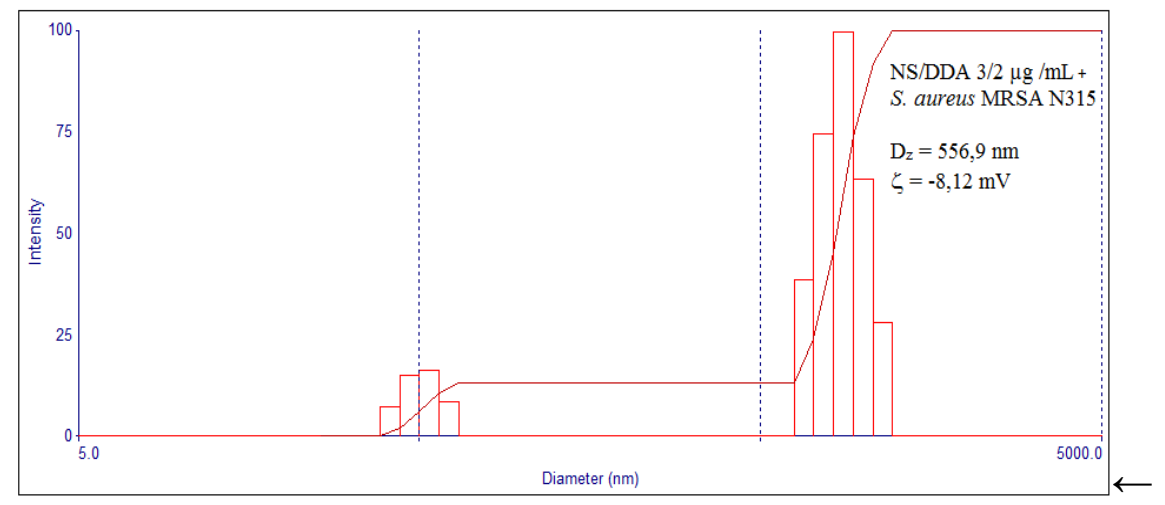

F

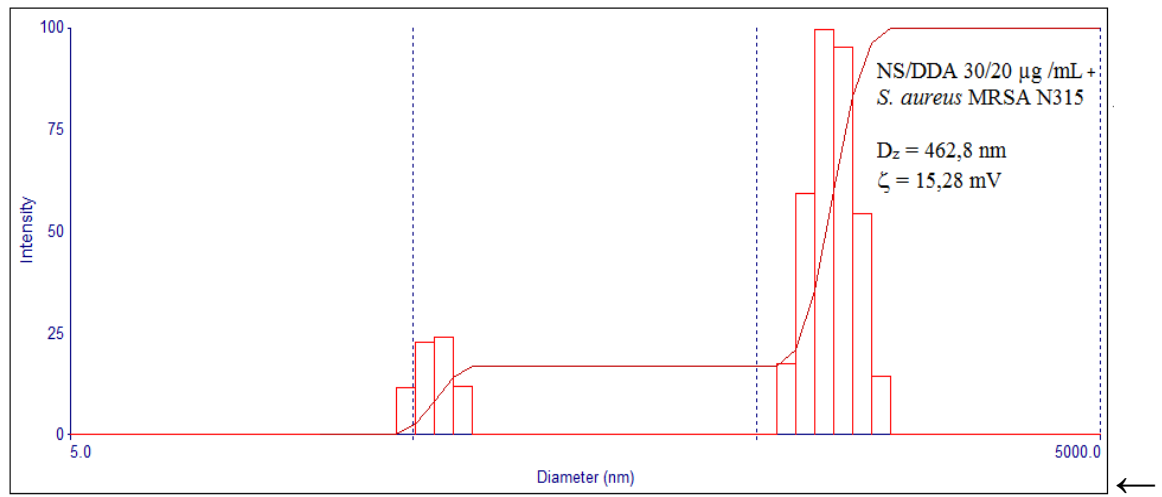

G

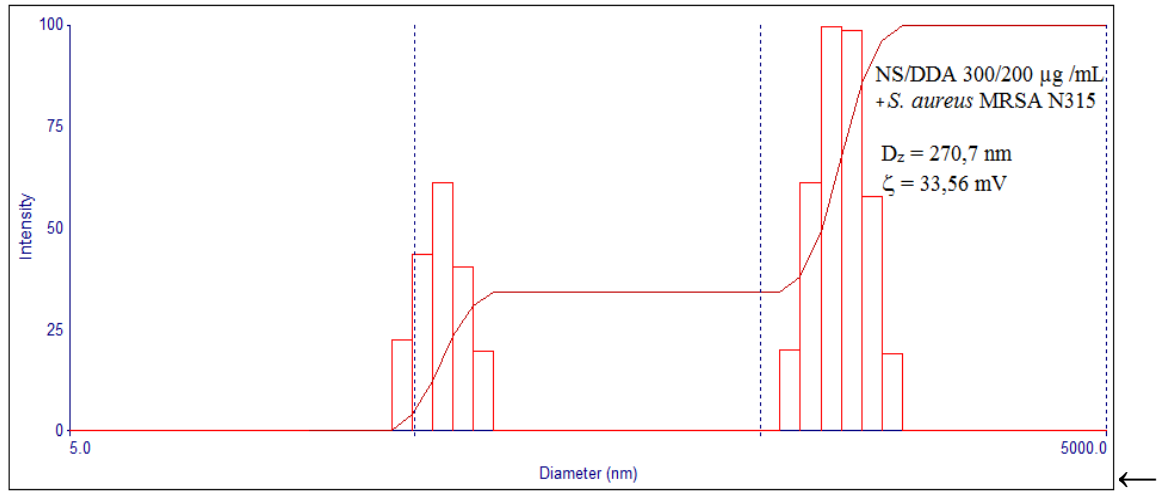




\section{DISCUSSÃO}

Na pecuária leiteira, os antibióticos são usualmente utilizados na prevenção e no tratamento das mastites bovinas. No entanto, seu uso frequente e inadequado aumenta a pressão de seleção, além de favorecer a disseminação de genes de resistência às bactérias sensíveis, comprometendo a eficiência do tratamento (SZWEDA et al., 2014). Staphylococcus spp., um dos principais gêneros isolados de vacas com mastite, é frequentemente descrito como microrganismo resistente à diversas classes de antibióticos, em especial aos betalactâmicos, bastante utilizados em propriedades leiteiras, dificultando o tratamento das infecções e controle desse patógeno (MATHEW; CISSELL; LIAMTHONH, 2007).

Neste estudo, as cepas selecionadas apresentaram uma maior taxa de resistência à penicilina e ampicilina, tanto S. aureus como as espécies de CoNS (Tabela 2). Índices elevados de resistência aos beta-lactâmicos tem sido relatados em rebanhos de diferentes localidades, e está associado ao uso rotineiro de formulações intramamárias contendo esses princípios ativos para o tratamento da mastite em vacas secas ou lactantes, além de outras infecções do gado leiteiro (da COSTA et al., 2013). Machado, Correa e Marin (2008), isolaram 109 CoNS de leite de vacas com mastite clínica e subclínica de 35 propriedades leiteiras no Brasil e encontraram resistência à penicilina em 93,5\% dos isolados, à sulfonamida $(88,9 \%)$, à novobiocina $(88,6 \%)$ e à ampicilina $(85,3 \%)$. Dez por cento dos isolados apresentaram resistência à todas as drogas avaliadas, e os autores concluíram que, provavelmente, essa alta resistência é consequência da pressão seletiva devida ao uso intensivo de drogas antimicrobianas.

Krewer et al. (2015) também encontraram alta frequência de resistência à ampicilina e amoxicilina $(67 \%)$ e a penicilina $(66 \%)$ em Staphylococcus spp. $(\mathrm{n}=218)$ isolados de mastite bovina no Nordeste brasileiro. Essa resistência foi correlacionada com a presença do gene blaZ, responsável pela produção da enzima beta-lactamase, detectada em 93,1\% das cepas.

Em um estudo feito em um rebanho leiteiro na China por Xu et al. (2015), também foi encontrado em mais de $80 \%$ das cepas de $S$. aureus $(\mathrm{n}=28)$ e CoNS $(\mathrm{n}=76)$, isolados de mastite bovina, fenótipo de resistência à penicilina. Segundo os autores, esse fato pode ser atribuído ao seu uso frequente em terapia de vaca seca na propriedade. Além disso, foi observada resistência à estreptomicina, kanamicina, tobramicina, cefoxitina, gentamicina, eritromicina, tetraciclina e clindamicina. A resistência a dois ou mais antibióticos estava presente em $95,7 \%$ dos S. aureus e 79,4\% de CoNS. Outro fator preocupante enfatizado é a presença do gene mecA em $35,7 \%$ dos S. aureus e $17,1 \%$ de CoNS, tornando os 
microrganismos resistentes à todos os beta-lactâmicos. As taxas de cura da mastite por estafilococos resistentes à penicilina são inferiores às ocasionadas por cepas sensíveis, possivelmente devido a fatores de virulência relacionados à produção de beta-lactamase, ou fatores de farmacocinética ou farmacodinâmica (TAPONEN et al., 2003).

A elevada resistência antimicrobiana às drogas frequentemente utilizadas nos rebanhos leiteiros, aliada à fatores de virulência presentes em Staphylococcus spp., torna a mastite uma doença onerosa. Sendo assim, há uma necessidade crescente de se encontrar novas moléculas com ação antimicrobiana frente a esses microrganismos resistentes. Uma alternativa promissora para o tratamento e profilaxia das mastites provocadas por patógenos Grampositivos é o emprego da bacteriocina nisina. Além do seu efeito bactericida em concentrações nanomolares, a nisina possui a vantagem de não apresentar toxicidade e não afetar muito a microbiota do hospedeiro. Ainda, os resíduos que possam permanecer no alimento não alteram o sabor ou odor, são digeridos por enzimas proteolíticas presentes no trato gastrointestinal e não entram na corrente sanguínea (CLEVELAND et al., 2001; NIGAM; GUPTA; SHARMA, 2014).

Os resultados da avaliação da CBM obtidos neste estudo mostraram que a nisina apresentou atividade bactericida in vitro com $\mathrm{CBM}_{50}$ de $50 \mu \mathrm{g} / \mathrm{mL}$ frente às cepas de Staphylococcus spp. isoladas de mastite bovina, assim como às cepas ATCC ${ }^{\circledR}$ (Tabela 2). A ação antimicrobiana da nisina também foi observada por Szweda et al. (2014), quando avaliaram drogas alternativas contra 37 cepas de $S$. aureus resistentes isoladas de mastite bovina. Os autores analisaram a atividade da nisina, da lisostafina e polimixina B, uma droga utilizada em infecções causadas por patógenos Gram-negativos. Todas as cepas foram sensíveis à lisostafina, 54\% à nisina (breakpoint $\mathrm{MIC}=32 \mu \mathrm{g} / \mathrm{mL}$, em caldo Müeller-Hinton, estabelecido pelos autores), e a polimixina B, só conseguiu inibir o crescimento em concentrações elevadas $(32-128 \mu \mathrm{g} / \mathrm{mL})$, desqualificando-a como agente quimioterápico alternativo em infecções estafilocócicas.

$\mathrm{O}$ efeito bactericida de formulações comerciais à base de nisina já foi comprovado em soluções pré-dipping por Sears et al. (1992), ocasionando pouca ou nenhuma irritação à pele do teto. Tratamentos intramamários para a mastite bovina também já foram avaliados por Cao et al. (2007), que compararam a eficácia de dois tratamentos, um a base de nisina e outro com gentamicina. Os dois tratamentos mostraram-se estatisticamente equivalentes em cura clínica e bacteriológica. Além disso, eles observaram que a nisina, por ser uma molécula relativamente grande, não pode mover-se da glândula mamária tratada para a glândula sadia, ao passo que a gentamicina foi detectada tanto nos quartos tratados, quanto nos não tratados. 
Esse fato pode representar uma vantagem aos produtores, uma vez que poderão descartar apenas o leite dos quartos tratados, diminuindo assim os prejuízos econômicos. Além do mais, a utilização da gentamicina em gado leiteiro não é aprovada em muitos países, como os Estados Unidos e a China, pois pode causar efeitos ototóxicos, nefrotóxicos e deficiências imunológicas. No entanto, o uso deste antibiótico é muito comum (TAN et al., 2009).

Wu, Hu e Cao (2007) também avaliaram a eficácia da nisina $\mathrm{Z}$ no tratamento da mastite subclínica e observaram taxas de cura estatisticamente significativa no grupo tratado em relação aos controles negativos.

Apesar do grande potencial antimicrobiano da nisina, sua associação com outras substâncias pode reduzir as doses terapêuticas, efeitos adversos e a duração do tratamento, além de aumentar seu espectro de ação (SILVA et al., 2011).

O DDA, além de possuir potente ação bactericida contra muitas espécies de microrganismos, incluindo bactérias multirresistentes, possui regiões hidrofóbicas capazes de transportar antibióticos, drogas, antígenos, ao qual possam exibir efeitos sinérgicos ou exibir propriedades bactericidas por si só (CARMONA-RIBEIRO; VIEIRA; LINCOPAN, 2006; PACHECO; CARMONA-RIBEIRO, 2003). Baseado nisso, foi avaliado também a atividade bactericida do lipídeo catiônico DDA e sua sinergia com a nisina, denominado de complexo NS/DDA, frente às cepas de $S$. aureus e CoNS, isoladas de mastite bovina e também às cepas $\mathrm{ATCC}^{\circledR}$.

As técnicas de checkerboard e time-kill são muito utilizadas em estudos in vitro de sinergia de combinações antimicrobianas. A técnica de checkerboard é baseada em microdiluicões, ao qual são determinadas as CIM de dois fármacos isoladamente e em associação. Este método avalia a evolução da CIM individual de cada fármaco na presença de um segundo fármaco. O time-kill avalia a interação entre duas drogas em diferentes concentrações ao longo de um intervalo de tempo, sendo os resultados obtidos com base na determinação de UFCs (LORIAN, 2005).

O DDA apresentou atividade bactericida com $\mathrm{CBM}_{50}$ de $4 \mu \mathrm{g} / \mathrm{mL}$ e o complexo NS/DDA apresentou $\mathrm{CBM}_{50}$ de $3 / 2 \mu \mathrm{g} / \mathrm{mL}$. Entretanto, é importante salientar que, apesar do complexo NS/DDA apresentar efeito parcialmente sinérgico e indiferente frente à 51,4 e 45,9\% das cepas, respectivamente, a associação de ambos ocasionou um aumento de sensibilidade à nisina, diminuindo a $\mathrm{CBM}_{50}$ de $50 \mu \mathrm{g} / \mathrm{mL}$ para $3 \mu \mathrm{g} / \mathrm{mL}$, atividade também observada contra as cepas MRSA (Tabela 2). Outro fator a ser ressaltado é que, através do time-kill foi possível observar uma redução de $\geq 3 \log _{10}$ UFC/mL após uma hora de interação entre o complexo NS/DDA $3 / 2 \mu \mathrm{g} / \mathrm{mL}$ e a cepa $S$. aureus $\mathrm{N} 315$, enquanto que a nisina 50 
$\mu \mathrm{g} / \mathrm{mL}$ sozinha atingiu essa redução após duas horas e o DDA $4 \mu \mathrm{g} / \mathrm{mL}$, após três horas (Figura 6). De acordo com Mitsugui et al. (2011), mesmo que combinações de fármacos não resultem em sinergia, as reduções nas CIMs são importantes, pois sugerem que pode ser possível administrar estas drogas desde que haja ajustes nas dosagens, permitindo assim um tratamento eficaz com redução nos possíveis efeitos adversos.

Outros resultados interessantes foram observados para as cepas $7 \mathrm{~N}\left(S\right.$. sciuri) e ATCC $^{\circledR}$ BAA-977TM (S. aureus). Apesar de estas cepas possivelmente terem apresentando uma CBM mais elevada para o lípide catiônico em comparação as CBMs das outras cepas, tanto sozinho quanto combinado com a nisina, a associação apresentou um efeito parcialmente sinérgico, com redução das CBMs de ambas as drogas. Segundo Rahal (2006), a combinação de agentes antimicrobianos pode prevenir o desenvolvimento de resistência ao antibiótico ativo por meio da adição de um agente inativo.

Com o objetivo de encontrar novas estratégias contra patógenos resistentes, Tong et al. (2014) avaliaram o uso combinado de nisina com 18 diferentes antimicrobianos contra diversas cepas de Enterococcus faecalis. Os autores observaram que a atividade antibacteriana dos antibióticos foi significativamente melhorada quando associada com 200 $\mathrm{UI} / \mathrm{mL}$ de nisina (1 UI = 0,025 $\mu \mathrm{g} / \mathrm{mL}$ [FAO JECFA, 2013]), e constataram que a formação de poros na superfície bacteriana pela nisina facilita a penetração de outros antibióticos.

A eficiência antimicrobiana e de transporte de moléculas pelo DDA também foi confirmada por Barbassa, Mamizuka e Carmona-Ribeiro (2011). As autoras avaliaram a atividade antimicrobiana do DDA, da rifampicina e a associação de ambos (DDA/RIF) contra patógenos causadores da tuberculose Mycobacterium smegmatis e Mycobacterium tuberculosis. As formulações de DDA e rifampicina sozinhas apresentaram atividade micobactericida, porém DDA/RIF resultou numa combinação mais eficaz, pois atuou em doses reduzidas. Lincopan, Mamizuka e Carmona-Ribeiro (2003) demonstraram que a associação de DDA com a anfotericina B resultou em uma formulação monomérica quimicamente estável, com excelente atividade fungicida contra a candidíase sistêmica em ensaios in vitro e in vivo, apresentando baixa nefrotoxicidade.

Outra vantagem de se associar duas drogas é a capacidade de ampliar o espectro de ação. Singh, Prabha e Rishi (2013) demonstraram que, apesar de a nisina atuar geralmente contra microrganismos Gram-positivos, quando associada à antibióticos convencionais, foi capaz de aumentar a eficácia destes agentes frente às cepas de Salmonella enterica serovar Typhimurium, com valores de CIM muito mais baixos que os frequentemente utilizados e redução no tempo de morte, tanto em ensaios in vitro como in vivo. Essa redução pode evitar 
ou reduzir o desenvolvimento de resistência aos antibióticos emergentes, assim como os efeitos colaterais.

O efeito bactericida do complexo NS/DDA também foi observado na microscopia de fluorescência, onde após seis horas de interação, a maior parte das cepas corou-se de vermelho, o que corresponde possivelmente ao dano à membrana celular ou morte bacteriana (Figura 7). Provavelmente, a adsorção das moléculas sobre as células bacterianas ocorre através da atração eletrostática entre o complexo catiônico NS/DDA e a superfície negativa da bactéria. Os domínios negativamente carregados presentes na estrutura da parede celular bacteriana favorecem essa interação. Campanhã, Mamizuka e Carmona-Ribeiro (1999) demonstraram que existe uma clara correlação entre a adsorção de vesículas catiônicas, que geram uma carga positiva nas superfícies celulares bacterianas, e morte celular. Além disso, as células carregadas negativamente são $100 \%$ viáveis, enquanto que as células de carga positiva não sobrevivem. Provavelmente, o complexo NS/DDA reverte à carga da superfície celular bacteriana, e então penetra na parede celular bacteriana. Em seguida, a nisina, através da ligação com o lípide II, forma poros na membrana citoplasmática, seguida de desorganização da membrana, e vazamento de material de baixo peso molecular intracelular, assim como inibição da síntese da parede. Esta associação resultou então, em um complexo cujo efeito bactericida teve seu potencial aumentado, em concentrações muito menores.

As técnicas de Light Scattering e potencial Zeta foram utilizadas com o intuito de elucidar a interação físico-química do complexo NS/DDA. A Light Scattering, ou espalhamento de luz dinâmica, determina a distribuição dos tamanhos das partículas em dispersão (diâmetro médio) e também, analisa o grau de associação e dissociação entre as partículas (polidispersão) (BERNE; PECORA, 2000). Já o potencial Zeta é uma medida da magnitude da repulsão ou da atração eletrostática ou das cargas entre partículas, sendo um dos parâmetros fundamentais que afetam a estabilidade. Sua medição oferece uma visão detalhada sobre as causas da dispersão, agregação ou floculação, podendo ser aplicada para melhorar a formulação de dispersões, emulsões e suspensões (MOUDGIL; SCHEINER, 1989).

Inicialmente, pode-se observar que a nisina possui uma estrutura flexível, cujo arranjo supramolecular é governado por diferentes condições físico-químicas inerentes à molécula, a qual possui aminoácidos carregados positiva e negativamente, assim como, resíduos hidrofóbicos e hidrofílicos. Assim, tanto a sua solubilização como incorporação é dependente do $\mathrm{pH}$ que pode afetar o pKa de alguns resíduos. Na condição estudada, em baixa força iônica (tampão IGP, pH=7,0), tanto pela distribuição de tamanhos, como carga superficial do complexo NS/DDA (Figura 8), fica evidente que a nisina forma um complexo catiônico com 
o DDA. Possivelmente, a solubilização da nisina, uma molécula anfipática, ocorre através da atração eletrostática entre os aminoácidos não catiônicos presentes em sua molécula, com a cabeça polar catiônica do DDA, e também através da incorporação pela hidrofobicidade da nisina diretamente com a porção hidrofóbica da bicamada do DDA.

Nossos resultados sugerem que o complexo NS/DDA pode representar um potencial agente antibacteriano frente à Staphylococcus spp. resistentes isolados de mastite bovina. A associação de novas alternativas antimicrobianas juntamente com medidas de higiene de ordenha favorece o controle de agentes patogênicos responsáveis pela mastite bovina.

Apesar de nossos resultados serem promissores, requerem mais estudos no intuito de se obter uma melhor compreensão do mecanismo de interação entre as moléculas do complexo NS/DDA, assim como a estabilidade da formulação. Adicionalmente, novos ensaios in vitro com outros gêneros bacterianos, tanto com outras bactérias Gram-positivas, como com Gramnegativas significativas para a etiologia da mastite bovina, com a finalidade de avaliar o espectro de ação do complexo NS/DDA. Além disso, ensaios de toxicidade e a pesquisa de possíveis resíduos que possam contaminar o leite são necessários. 


\section{CONCLUSÕES}

O complexo NS/DDA se mostrou como uma alternativa promissora para o controle de Staphylococcus spp. resistentes isolados de mastite bovina. A combinação da nisina com o DDA resultou em um complexo antibacteriano eficaz, com atividade bactericida obtida em baixa concentração na primeira hora de interação, quando comparada com as duas moléculas sozinhas. A terapia combinada permite a administração de doses mais baixas de cada um dos antimicrobianos, a fim de reduzir a sua toxicidade, os efeitos adversos e impedir o desenvolvimento de mutantes resistentes, além de ampliar o espectro de ação. 


\section{REFERÊNCIAS*}

ADETUNJI, V. O. Effects of processing on antibiotic residues (Streptomycin, Penicillin-G and Tetracycline) in soft cheese and yoghurt processing lines. Pakistan Journal of Nutrition, v. 10, n. 8, p. 792-795, 2011.

ALMEIDA, L. P.; VIEIRA, R. L.; ROSSI, D. A.; CARNEIRO, A. L.; ROCHA, M. L. Antibiotic residues in milk of rural properties of Uberlândia - MG region. Bioscience Journal, v. 19, n. 3, p. 83-87, 2003.

ALTERTHUM, F. Mecanismo de ação dos antibacterianos e mecanismos de resistência. In: TRABULSI, L. R., et al. Microbiologia, 4. ed. São Paulo: Atheneu, 2005, p. 79-84.

ANONYMOUS. Synergism testing: broth microdilution checkerboard and broth macrodilution methods. In: H.D. Isenberg (Ed.), Clinical Microbiology Procedures Handbook. American Society for Microbiology, Washington, DC: ASM, 1992. p. 5.18.15.18.28.

ARANHA, C.; GUPTAA, S.; REDDYA, K. V. R Contraceptive efficacy of antimicrobial peptide Nisin: in vitro and in vivo studies. Contraception, v. 69, n. 4, p. 333-338, 2004.

ARAUZ, L. J.; JOZALA, A. F.; MAZOLLA, P. G.; PENA, V. T. C. Nisin biotechnological production and application: A review. Trends in Food \& Technology, v. 20, p. 146-154, 2009.

ARCURI, E. F.; ÂNGELO, F. F.; GUIMARÃES, M. F. M.; TALON, R.; BORGES, M. F.; LEROY, S.; LOISEAU, G.; LANGE, C. C.; ANDRADE, N. J.; MONTET, D. Toxigenic status of Staphylococcus aureus isolated from bovine raw milk and Minas frescal cheese in Brazil. Journal of Food Protection, v. 12, p. 2148-2349, 2010.

ASADUZZAMAN, S. M.; SONOMOTO, K. Lantibiotics: diverse activities and unique modes of action. Journal of Bioscience and Bioengineering, v. 107, n. 5, p. 475-487, 2009.

ATULYA, M.; MATHEW, A. J.; RAO J. V.; RAO, C. M. Influence of milk components in establishing biofilm mediated bacterial mastitis infections in cattle: a fractional factorial approach. Research in Veterinary Science, v. 96, p. 25-27, 2014.

BAKER, M. D.; ACHARYA, K. R. Superantigens: structure-functions relationships. International Journal of Medical Microbiology, v. 293, n. 7-8, p. 529-537, 2004.

BANNERMAN, T. L.; PEACOCK, S. Staphylococcus and Micrococcus. In: MURRAY, P. R. et al. Manual of Clinical Microbiology, 9. ed. Washington: ASM Press, 2007. v. 1., chap. 28, p. 390-411.

BARBASSA, L.; MAMIZUKA, E. M.; CARMONA-RIBEIRO, A. M. Supramolecular assemblies of rifampicin and cationic bilayers: preparation, characterization and micobactericidal activity. BMC Biotechnology, v. 11, n. 40, p. 1-8, 2011.

\footnotetext{
* De acordo com: ASSOCIAÇÃO BRASILEIRA DE NORMAS TÉCNICAS. NBR 6023: Informação e documentação: referências: elaboração: Rio de Janeiro, 2002.
} 
BARBOSA-CORONA, J. E.; SALCIDO, N. F.; MURILLO, N. A.; ZARZOSA, A. O.; MEZA, J. E. O. Activity of bacteriocins synthesized by Bacillus thuringiensis against Staphylococcus aureus isolates associated to bovine mastitis. Veterinary Microbiology, v. 138, p. 179-183, 2009.

BASTOS, M. C. F.; CEOTTO, H.; COELHO, M. L. V.; NASCIMENTO, J. S. Staphylococcal antimicrobial peptides: relevant properties and potential biotechnological applications. Current Pharmaceutical Biotechnology, v. 10, p. 38-61, 2009.

BERNE, B. J.; PECORA, R. Dynamic Light Scattering: With Applications to Chemistry, Biology, and Physics. Mineola. New York: Courier Dover Publications, 2000. 692 p.

BORGES, M. F.; NASSU, R. T.; PEREIRA, J. L.; ANDRADE, A. P. C.; KUAYE, A. Y. Perfil de contaminação por Staphylococcus e suas enterotoxinas e monitorizarão das condições de higiene em uma linha de produção de queijo de coalho. Ciência Rural, Santa Maria, v. 38, n. 5, p. 1431-1438, 2008.

BOUlOS, L.; PRÉVOST, M.; BARBEAU, B.; COALlIER, J.; DESJARDINS, R. LIVE/DEAD, BacLight, application of a new rapid staining method for direct enumeration of viable and total bacteria in drinking water. Journal of Microbiological Method, v. 37, p. 77 86, 1999.

BROADBENT, J. R.; CHOU, Y. C.; GILLIES, K.; KONDO, J. K. Nisin inhibits several Gram-positive, mastitis-causing pathogens. Journal of Dairy Science, v. 72, n. 12, p. 33423345, 1989.

CAMPANHÃ, M. T. N.; MAMIZUKA, E. M.; CARMONA-RIBEIRO, A. M. Interactions between cationic liposomes and bacteria: the physical-chemistry of the bactericidal action. Journal of Lipid Research, v. 40, p. 1495-1500, 1999.

CAO, L. T.; WU, J. Q.; XIE, F.; HU, S. H.; MO, Y. Efficacy of nisin in treatment of clinical mastitis in lactating dairy cows. Journal of Dairy Science, v. 90, p. 3980-3985, 2007.

CARMONA-RIBEIRO, A. M. Bilayer-Forming Synthetic Lipids: Drugs or Carriers? Current Medicinal Chemistry, v. 10, p. 2425-2446, 2003.

CARMONA-RIBEIRO, A. M.; CARRASCO, L. D. M. Cationic antimicrobial polymers and their assemblies. International Journal Molecular Sciences, v. 14, p. 9906-9946, 2013.

CARMONA-RIBEIRO, A. M.; CASTUMA, C. E.; SESSO, A.; SCHREIER, S. Bilayer structure and stability in dihexadecylphosphate dispersions. Journal of Physical Chemistry, v. 95, p. 5361-5366, 1991.

CARMONA-RIBEIRO, A. M.; CHAIMOVICH, H. Preparation and characterization of large dioctadecyldimethylammonium chloride liposomes and comparison with small sonicated vesicles. Biochimica et Biophysica Acta, v. 24, n. 1, p. 172-179, 1983.

CARMONA-RIBEIRO, A. M.; VIEIRA, D. B.; LINCOPAN, N. Cationic surfactants and lipids as anti-infective agents (Review). Anti-Infective Agents in Medicinal Chemistry, v. 5, p. 33-54, 2006. 
CARMONA-RIBEIRO, A. M.; ORTIS, F.; SCHUMACHER, R. I.; ARMELIN, M. C. S. Interactions between cationic vesicles and cultured mammalian cells. Langmuir, v. 13, n. 8, p. 2215-2218, 1997.

CARR, F. J.; CHILL, D.; MAIDA, N. The lactic acid bacteria: A literature survey. Critical Reviews in Microbiology, v. 28, p. 281-370, 2002.

CARRASCO, L. D. M.; SAMPAIO, J. L. M.; CARMONA-RIBEIRO, A. M. Supramolecular cationic assemblies against multidrug-resistant microorganisms: activity and mechanism of action. International Journal of Molecular Science, v. 16, n. 3, p. 6337-6352, 2015.

CASTElANI, L.; PILON, L. E.; MARTINS, T.; POZZI, C. R.; ARCARO, J. R. P. Investigation of biofilm production and icaA and icaD genes in Staphylococcus aureus isolated from heifers and cows with mastitis. Animal Science Journal, v. 86, n. 3, p.340-344, 2014.

CASTELLANO, P.; BELFIORE, C.; VIGNOLO, G. Combination of bioprotective cultures with EDTA to reduce Escherichia coli O157:H7 in frozen ground-beef patties. Food Control, v. 22, n. 8, p. 1461-1465, 2011.

CERQUEIRA, M. M. O. P.; SOUZA, F. N.; CUNHA, A. F.; PICININ, L. C. A.; LEITE, M. O.; PENNA, C. F. A. M.; SOUZA, M. R.; FONSECA, L. M. Detection of antimicrobial and anthelmintic residues in bulk tank milk from four different mesoregions of Minas Gerais State - Brazil. Arquivo Brasileiro de Medicina Veterinária e Zootecnia, v. 66, n. 2, p. 621$625,2014$.

CHAMBERS, H. F. Methicillin resistance in Staphylococci: molecular and biochemical basis and clinical implications. Clinical Microbiology Review, v. 10, p. 781-791, 1997.

CHATTERJEE, C.; PAUL, M.; XIE, L.; van der DONK, W. A. Biosynthesis and mode of action of lantibiotics. Chemical Reviews, v. 105, p. 633-684, 2005.

CHRISTIAN, T.; SCHNEIDER, R. J.; FÄRBER, H. A.; SKUTLAREK, D.; MEYER, M. T.; GOLDBACH, H. E. Determination of antibiotic residues in manure, soil, and surface waters. Acta Hydrochimica at Hydrobiologica, v. 31, p. 36-44, 2003.

CLEVELAND, J.; MONTVILLE, T. J.; NES, I. F.; CHIKINDAS, L. M. Bacteriocins: Safe, natural antimicrobial for food preservation. International Journal of Food Microbiology, v. 71, p. 1-20, 2001.

CLSI - Clinical and Laboratory Standards Institute. Performance Standards for Antimicrobial Susceptibility Testing; Twenty-Third Informational Supplement. Wayne, PA: Clinical and Laboratory Standards Institute, 2013. 199 p. [CLSI document M100-S23].

CLSI - Clinical and Laboratory Standards Institute. Performance Standards for Antimicrobial Disk and Dilution Susceptibility Tests for Bacteria isolated from Animals; Approved Standard-Third Edition. Wayne, PA: Clinical and Laboratory Standards Institute, 2008. 99 p. [CLSI document M31-A3]. 
COELHO, S. M. O.; REINOSO, E.; PEREIRA, I. A.; SOARES, L. C.; DEMO, M.; BOGNI, C.; SOUZA, M. M. S. Virulence factors and antimicrobial resistance of Staphylococcus aureus isolated from bovine mastitis in Rio de Janeiro. Pesquisa Veterinária Brasileira, v. 29, n. 5, p. 369-374, 2009.

COSTA, E. O.; RAIA, R.; WATANABE, E. T.; GARINO JR, F.; COELHO, V. Influência do tratamento intramamário de casos de mastite de bovinos em lactação em relação à presença de resíduos de antibióticos no leite dos quartos sadios e tratados. Revista Napgama, v. 3, p. 14$17,2000$.

COSTERTON, J. W.; STEWART, P. S.; GREENBERG, E. P. Bacterial biofilms: a common cause of persistent infections. Science, v. 284, n. 5418, p. 1318-22, 1999.

COTTER, P. D.; ROSS, R. P.; HILL, C. Bacteriocins - a viable alternative to antibiotics? Nature Reviews Microbiology, v. 11, p. 95-105, 2013.

da COSTA, M. C.; BARROS, R. A.; CUSTÓDIO, D. A. C.; PEREIRA, U. P.; FIGUEIREDO, D. J.; SILVA, D. Resistência a antimicrobianos em Staphylococcus aureus isolados em mastite em bovinos leiteiros de Minas Gerais, Brasil. Arquivos do Instituto Biológico, v. 80, n. 3, p. 297-302, 2013.

de LENCASTRE, H. S. A.; FIGUEIREDO, A. S.; URBAN, C.; TOMASZ, A. Multiple mechanisms of methicillin-resistance and improved methods for detection in clinical isolates of S. aureus. Antimicrobial Agents and Chemotherapy, v. 35, p. 632-639, 1991.

DELVES-BROUGHTO, J. Nisin as a foof preservative. Food Australia, v. 57 n.12, p. 525 $527,2005$.

DELVES-BROUGHTON, J.; BLACKBURN, P.; EVANS, R. J.; HUGENHOLTZ, J. Applications of the bacteriocin, nisin. Antonie Van Leeuwenhoek, v. 69, n. 2, p. 193-202, 1996.

ERSKINE, R. J.; WALKER, R. D.; BOLIN, C. A.; BARTLETT, P. C.; WHITE, D. G. Trends in antibacterial susceptibility of mastitis pathogens during a seven-year period. Journal of Dairy Science, v. 85, p. 1111-8, 2002.

FAGUNDES, H.; OLIVEIRA, C. A. F. Infecções intramamárias causadas por Staphylococcus aureus e suas implicações em saúde pública. Ciência Rural, v. 34, n. 4, p. 1315-1320, 2004.

FAO JECFA, Monographs 14. Compendium of Food Additive Specifications. Joint Expert Committee on Food Additives, 77th Meeting, Rome, Italy: FAO/WHO, 2013. p. 4-13.

FEITOSA, E.; BARRELEIRO, P. C. A.; OLOFSSON, G. Phase transition in dioctadecyldimethylammonium bromide and chloride vesicles prepared by different methods. Chemistry and Physics of Lipids, v. 105, p. 201-213, 2000.

FERNANDEZ-CUENCA, F.; MARTÍNEZ-MARTÍNEZ, L.; PASCUAL, A.; PEREA, E. J. In vitro activity of azithromycin in combination with amikacin, ceftazidime, cirpofloxacin or imipenem against clinical isolates of Acinobacter baumannii. Chemotherapy, v. 49, n. 1-2, p. 24-26, 2003. 
FRANCO, B. D. G. M; LANDGRAF, M. Microbiologia de Alimentos. São Paulo: Atheneu, 2004. 182 p.

FRANK, K. L.; REICHERT, E. J.; PIPER, K. E.; PATEL, R. In vitro effects of antimicrobial agents on planktonic and biofilm forms of Staphylococcus lugdunensis clinical isolates. Antimicrobial Agents and Chemotherapy, v. 51, p. 888-895, 2007.

GIAMARELLOS-BOURBOLIS, E. J.; GRECKA P; GIAMARELLOU, H. Comparative in vitro interactions of ceftazidime, meropenem, and imipenem with amikacina on multiresistant Pseudomonas aeruginosa. Diagnostic Microbiology and Infectious Disease, v. 29, n. 2, p. 81-6, 1997.

HALL, M. J.; MIDDLETON, R. F., WESTMACOTT, D. The fractional inhibitory concentration (FIC) index as a measure of synergy. Journal Antimicrobial Chemotherapy, v. 11, n. 5, p. 427-33, 1983.

HARMON, R. J.; EBERHART, R. J.; JASPER, D. E.; LANGLOIS, B. E.; WILSON, R. A. Microbiological procedures for the diagnosis of bovine udder infection. Arlington: National Mastitis Council, 1990. 34 p.

HARRIS, L. J.; FLEMING, H. P.; KLAENHAMMER, T. R. Developments in nisin research. Food Research International, v. 25, n. 1, p. 57-66, 1992.

HOGAN, J.; SMITH, K. L. Managing Environmental Mastitis. Veterinary Clinics of North America: Food Animal Practice, v. 28, n. 2, p. 217-224, 2012.

HOOVER, G. D.; STEENSON, L. R. Bacteriocins of lactic acid bacteria. San Diego, Calif: Academic Press, 1993. 275 p.

HUGO, W. B. Disinfection mechanisms. In: In: RUSSELL, A. D., HUGO, W. B., AYLIFFE, G. A. J. Principles and practice of disinfection, preservation and sterilization. 3. ed. Oxford, UK: Blackwell Scientific Publications, 1999. p. 258-283.

JACK, R. W.; TAGG, J. R.; RAY, B. Bacteriocins of Gram-Positive Bacteria. Microbiological Reviews, v. 59, n. 2, p. 171-200, 1995.

JACOBSON, B.; CONSUMER, S. Antibiotics in beef. Colorado State University Cooperative Extension, Douglas County. Disponível em: <http:www.ext.colostate.edu /PUBS/COLUMNCC/cc990115.html>. Acesso em: 26/06/2014.

JOSALA, A. F.; ARAUZ, L. J.; MAZZOLA, P. G.; PENNA, T. C. V. Nisin biotechnological production and application: a review. Trends in Food Science and Technology, v. 20, p. 146-154, 2009.

JUYAL, D.; SHAMANTH, A.; PAL, S.; SHARMA, M. K.; PRAKASH, R.; SHARMA, N. The prevalence of inducible clindamycin resistance among Staphylococci in a tertiary care hospital - A study from the Garhwal Hills of Uttarakhand, India. Journal of Clinical and Diagnostic Research, v. 7, n. 1, p. 61-65, 2013. 
KALMUS, P.; AASMAE, B.; KARSSIN, A.; ORRO, T.; KASK, K. Udder pathogens and their resistance to antimicrobial agents in dairy cows in Estonia. Acta Veterinaria Scandinavica, v. 53, p. 1-7, 2011.

KATZ, D. S.; INBAR, I.; SAMINA, I.; PELEG, B. A.; HELLER, D. E. Comparison of dimethyl dioctadecyl ammonium bromide, Freund's complete adjuvant and mineral oil for induction of humoral antibodies, cellular immunity and resistance to Newcastle disease virus in chickens. FEMS Immunology and Medical Microbiology, v. 7, p. 303-313, 1993.

KEEFE, G. Update on control of Staphylococcus aureus and Strepotococcus agalactiae for management of mastitis. Journal of Veterinary Clinics of North America: Food Animal Practice, v. 28, n. 2, p. 203-216, 2012.

KEMPER, N. Veterinary antibiotics in the aquatic and terrestrial environment. Ecological Indicators, v.8, p. 1-13, 2008.

KLAENHAMMER, T. R. Genetics of bacteriocins produced by lactic acid bacteria. FEMS Microbiology Reviews, v. 12, n 1-3, p. 39-85, 1993.

KLOOS, W. E.; BANNERMAN, T. L. Staphylococcus and micrococcus. In: MURRAY, P. R.; BARON, E. J.; PFALLER, M.A; TENOVER, F.C.; YOLKEN, R. H., eds. Manual of Clinical Microbiology, 6. ed. Washington, DC.: American Society Microbiology, 1999. p. 264-282.

KLOOS, W. E.; SCHLEIFER, K. H. Simplified scheme for routine identification of human Staphylococcus species. Journal of Clinical Microbiology, v. 1, p. 82-88, 1975.

KONEMAN, E. W.; ALLEN, S. D.; JANDA, W. M.; SCHRECKENBERGER, P. C.; WINN, W. C. Diagnóstico microbiológico. 5. Ed. São Paulo: Medsi, 2001. 1488 p.

KREWER C. C.; AMANSO, E. V.; GOUVEIA, G. V. SOUZA, R. L.; COSTA, M. M.; MOTA R. A. Resistance to antimicrobials and biofilm formation in Staphylococcus spp. isolated from bovine mastitis in the Northeast of Brazil. Tropical Animal Health and Production, v. 47, n. 3, p. 511-8, 2015.

KRUIJFF, B.; vanDAM, V.; BREUKINK, E. Lipid II: A central component in bacterial cell wall synthesis and a target for antibiotics. Prostaglandins, Leukotrienes and Essential Fatty Acids, v. 79, p. 117-121, 2008.

KUTAR, K.; VERMA, A. K.; SHARMA, B.; KUMAR, A.; YADAV, S. K. Analysis of mecA gene and antibiotic resistance in Staphylococcus aureus isolates from bovine mastitis. Indian Journal of Comparative Microbiology, Immunology and Infectious Diseases, v. 6, n. 1, p. 22-27, 2015.

LÁZARO-DÍEZ, M.; REMUZGO-MARTÍNEZ, S.; RODRÍGUEZ-MIRONES， C.; ACOSTA, F.; ICARDO, J. M.; MARTÍNEZ-MARTÍNEZ, L.; RAMOS-VIVAS, J. Effects of subinhibitory concentrations of ceftaroline on Methicillin-Resistant Staphylococcus aureus (MRSA) Biofilms. PLoS ONE, v. 11, n. 1, p. e0147569, 2016. 
LE LAY, C.; AKEREY, B.; FLISS, I.; SUBIRADEZ, M.; ROUABHIA, M. Nisin Z inhibits the growth of Candida albicans and its transition from blastospore to hyphal form. Journal of Applied Microbiology, v. 105, p. 1630-1639, 2008.

LEE, J. H. Methicilin (oxacilin)-resistant Staphylococcus aureus strains isolated from major food animals and their potencial transmission to humans. Applied and Environmental Microbiology, v. 69, p. 6489-6494, 2003.

LEWIS, J. S.; JORGENSEN, J. H. Inducible clindamycin resistance in staphylococci: should clinicians and microbiologists be concerned? Clinical Infectious Diseases, v. 40, p. 280-285, 2005.

LINA, G.; BOHACH, G. A.; NAIR, S. P.; HIRAMATSU, K.; JOUVIN-MARCHE, E.; MARIUZZA, R. Standard nomenclature fort the superantigens expressed by Staphylococcus. Journal of Infectious Diseases, v. 189, p. 2334-2336, 2004.

LINCOPAN, N.; CARMONA-RIBEIRO, A. M. Lipid-covered drug particles: combined action of dioctadecyldimethylammonium bromide and amphotericin $\mathrm{B}$ or miconazole. Journal of Antimicrobial Chemotherapy, v. 58, n. 1, p. 66-75, 2006.

LINCOPAN, N.; ESPÍNDOLA, N. M.; VAZ, A. J.; DA COSTA, M. H.; FAQUIM-MAURO, E.; CARMONA-RIBEIRO, A. M. Novel immunoadjuvants based on cationic lipid: preparation, characterization and activity in vivo. Vaccine, v. 27, p. 5760-5771, 2009.

LINCOPAN, N.; MAMIZUKA, E. M.; CARMONA-RIBEIRO, A. M. In vivo activity of a novel amphotericin B formulation with synthetic cationic bilayer fragments. Journal of Antimicrobial Chemotherapy, v. 52, n. 3, p. 412-8, 2003.

LORIAN, V. Antibiotics in laboratory medicine, 5. ed. Philadelphia: Lippincot Williams \& Wilkins, 2005. 889 p.

LUTHJE, P., SCHWARZ, S. Antimicrobial resistance of coagulase-negative staphylococci from bovine subclinical mastitis with particular reference to macrolide-lincosamide resistance phenotypes and genotypes. Journal of Antimicrobial Chemotherapy, v. 57, p. 966-969, 2006.

MACHADO, T. R. O.; CORREA, M. G.; MARIN, J. M. Antimicrobial susceptibility of coagulase-negative Staphylococci isolated from mastitic cattle in Brazil. Arquivo Brasileiro de Medicina Veterinária e Zootecnia, v. 60, n. 1, p. 278-282, 2008.

MARTIN, S. E.; MYERS, E. R.; LANDOLO, J. J. Staphylococcus aureus. In: HUI, Y. H.; PIERSON, M. D.; GORHAM, J. R. (Eds.). Foodborn disease handbook - bacterial pathogens. 2. ed. New York: Marcel Dekker, 2001. v. 1, p. 345-381.

MARTINS, L. M. S.; MAMIZUKA, E. M.; CARMONA-RIBEIRO, A. M. Cationic Vesicles as Bactericides. Langmuir, v. 13, p. 5583-5587, 1997.

MARTINS, R. P.; SILVA, J. A. G.; NAKAZATO, L; DUTRA, V.; ALMEIDA FILHO, E. S. Prevalência e etiologia infecciosa da mastite bovina na microrregião de Cuiabá, MT. Ciência Animal Brasileira, v. 11, n. 1, p. 181-187, 2010. 
MATHEW, A. G.; CISSELL, R.; LIAMTHONG, S. Antibiotic resistance in bacteria associated with food animals: a United States perspective of livestock production. Foodborne Pathogenes and Disease, v. 4, p. 115-133, 2007.

McAULIFFE, O.; ROSS, R. O.; HILL, C. Lantibiotics: Structure, biosynthesis and mode of action. FEMS Microbiology Reviews, v. 25, p. 285-308, 2001.

MELCHIOR, M. B.; VAARKAMP, H.; GREMMELS, J. F. Biofilms: A role in recurrent mastitis infections? The Veterinary Journal, v. 171, p. 398-407, 2006.

MELO, R. N.; SOARES, N. F. F.; GONÇALVES, M. P. J. C. Nisina: um conservante natural para alimentos. Revista Ceres, v. 52, n. 303, p. 321-338, 2005.

MENDONÇA, E. C. L.; MARQUES, V. F.; MELO, D. A.; ALENCAR, T. A.; COELHO, I. S.; COELHO, S. M. O.; SOUZA, M. M. S. Caracterização fenogenotípica da resistência antimicrobiana em Staphylococcus spp. isolados de mastite bovina. Pesquisa Veterinária Brasileira, v. 32, n. 9, p. 859-864, 2012.

MITSUGUI, C. S.; TOGNIM, M. C. B.; CARDOSO, C. L.; CARRARA-MARRONI, F. E.; GARCIA, L.B. In vitro activity of polymyxins in combination with b-lactams against clinical strains of Pseudomonas aeruginosa. International Journal of Antimicrobial Agents, v. 38, p. 447-450, 2011.

MONROE, D. Looking for chinks in the armor of bacterial biofilms. PLoS Biology, v. 5, n. 11, p. e307, 2007.

MORENO, I.; LERAYER, A. L; BALDINI, V. L. S.; LEITÃO, M. F. F. Efeito e modo de ação das bacteriocinas produzidas por Lactococcus lactis subsp. lactis ITAL 383, ATCC 11454 e CNRZ 150 contra Listeria innocua LIN 11. Ciência e Tecnologia de Alimentos, v. 19, n.1, 1999.

MOTTA, R. G.; FRANCO, M. M. J.; LISTONI, F. J. P.; MOTTA, I. G.; MOTTA, D. G.; RIBEIRO, M. G. Indicators of microbiological quality, physical chemistry and detection of antimicrobial residues in raw milk from cows collected of the southeastern state of São Paulo. Veterinária e Zootecnia, v. 20, n. 2, p. 116-118, 2013.

MOUDGIL, B.; SCHEINER, J. Flocculation and dewatering. In: LYKLEMA, J. The colloidal background of flocculation and dewatering. New York: Engineering. Foundation, 1989. p. 1-20.

NASCIMENTO, M. S.; MORENO, I.; KUAYE, A. Y. Bacteriocinas em alimentos: uma revisão. Brazilian Journal of Food Technology, v. 11, n. 2, p. 120-127, 2008.

NIGAM, A.; GUPTA, D.; SHARMA, A. Treatment of infectious disease: Beyond antibiotics. Microbiologycal Research, v. 169, p. 643-651, 2014.

NIKAIDO, H. Multidrug Resistance in Bacteria. Anual Review of Biochemistry, v. 78, p. 828, 2009. 
NISHIE, M.; NAGAO, J.; SONOMOTO, K. Antibacterial peptides "bacteriocins": an overview of their diverse characteristics and applications. Biocontrol Science, v. 17, n. 1, p. $1-16,2012$.

OLIVEIRA, C. P.; SIQUEIRA JR, J. P.; SILVA, J. A. Bacteriocinas como alternativa na conservação de alimentos. Revista Verde, v.7, n. 1, p. 09-15, 2012.

OLIVEIRA, T. R.; BENATI, C. R.; LAMY, M. T. Strutural chacacterization of the interaction of the polyene antibiotic amphotericin B with DODAB bicelles and vesicles. Biochimica et Biophysica Acta (BBA) - Biomembranes, v. 1808, n. 11, p. 2629-2637, 2011.

OLIVER, S. P.; MURINDA, S. E. Antimicrobial resistance of mastitis pathogens. Veterinary Clinics of North America: Food Animal Practice, v. 28, p. 165-185, 2012.

PACHECO, L. F.; CARMONA-RIBEIRO, A. M. Effects of synthetic lipids on solubilization and colloid stability of hydrophobic drugs. Journal of Colloid and Interface Science, v. 258, n. 1, p. 146-154, 2003.

PANSU, R. M.; ARRIO, B.; RONCIN, J.; FAURE, J. Vesicles versus membrane fragments in DODAC suspensions. The Journal of Physical Chemistry, v. 94, p. 796-801, 1990.

PARADA, J. L.; CARON, C. R.; MEDEIROS, A. B. P.; SOCCOL, C. R. Bacteriocins from lactic acid bacteria: purification, properties and use as biopreservatives. Brazilian Archives of Biology and Technology, v. 50, n. 3, p. 521-542, 2007.

PHILPOT, W. N., NICKERSON, S. C. Mastits: Counter Attack. Naperville, IL: Babson Bros. Co., 1991. 150 p.

PRAGER, M. D.; KANAR, M. C.; FARMER, J. L.; VANDERZEE, J. Effect of dimethyldioctadecyl-ammonium-bromide induced macrophages on malignant cell proliferation. Cancer Letter, v. 27, p. 225-235, 1985.

PU, W.; SU, Y.; LI, J.; LI, C; YANG, Z.; DENG, H.; NI, C. High incidence of oxacillinsusceptible mecA-positive Staphylococcus aureus (OS-MRSA) associated with bovine mastitis in China. PLoS ONE, v. 9, n. 2, e88134, 2014.

PYÖR̈̈LÄ, S.; TAPONEN, S. Coagulase-negative staphylococci - emerging mastitis pathogens. Veterinary Microbiology, v. 134, p. 1-2, 2009.

RACHID, S.; OHLSEN, K.; WITTE, W.; HACKER, J.; ZIEBUHR, W. Effect of subinhibitory antibiotic concentrations on polysaccharide intercellular adhesin expression in biofilm-forming Staphylococcus epidermidis. Antimicrobial Agents and Chemotherapy, v. 44, p. 3357-3363, 2000.

RADOSTITS, O. M.; GAY, C. C.; BLOOD, D. C.; HINCHCLIFF, K. W. Clínica veterinária: um tratado de doenças dos bovinos, ovinos, suínos, caprinos. 9. ed. Rio de Janeiro: Guanabara Koogan, 2002. 1772 p. 
RAHAL, J. J. Novel antibiotic combinations against infections with almost completely resistant Pseudomonas aeruginosa and Acinetobacter species. Clinical Infectious Diseases, v. 43, n. 2, p. S95-S99, 2006.

RAHIMI, E.; ALIAN, F. Presence of enterotoxigenic Staphylococcus aureus in cow, camel, sheep, goat, and buffalo bulk tank milk. Veterinarski Arhiv, v. 83, p. 23-30, 2013.

RAJARAM, G.; MANIVASAGAN, P.; GUNASEKARAN; THILAGAVATHI, B.; SARAVANAKUMAR, A. Purification and characterization of a bacteriocin produced by Lactobacillus lactis isolated from marine environment. Advance Journal of Food Science and Technology, v. 2, n. 2, p. 138-144, 2010.

RUEGG, P. L.; OLIVEIRA L.; JIN, W.; OKWUMABUA, O. Phenotypic antimicrobial susceptibility and occurrence of selected resistance genes in gram-positive mastitis pathogens isolated from Wisconsin dairy cows. Journal Dairy Science, v. 98, p. 4521-4534, 2015.

SAHM, D. F. Streptococci and Staphylococci: laboratory considerations for in vitro susceptibility testing. Clinical microbiology Newsletter, v. 16, p. 9-14, 1994.

SANTOS, M. V.; FONSECA, L. F. L. Estratégias para Controle de Mastite e Melhoria na Qualidade do Leite. Barueri: Manole, 2007. 314 p.

SAWANT, A. A.; SORDILLO, L. M.; JAYARAO, B. M. A survey on antibiotic usage in dairy herds in Pennsylvania. Journal of Dairy Science, v. 88, p. 2991-2999, 2005.

SCHALES, O.; SCHALES, S. S. A simple and accurate method for determination of chloride in biological fluids. Journal of Biological Chemistry, v. 140, p. 879-84, 1941.

SCHULZ, D.; PEREIRA, M. A.; BONELLI, R. R.; NUNES, M. M.; BATISTA, C. R. V. Bacteriocinas: mecanismo de ação e uso na conservação de alimentos. Alimentos e Nutrição, v. 14, n. 2, p. 229-235, 2003.

SEARS, P. M.; SMITH, B. S.; STEWART, W. K.; GONZALEZ, R. N.; RUBINO, S. D.; GUSIK, S. A.; KULISEK, E. S.; PROJAN, S. J.; BLACKBURN, P. Evaluation of a nisin based germicidal formulation on teat skin of live cows. Journal of Dairy Science, v. 75, p. 3185-3190, 1992.

SHEN, J.; WANG, Y.; SCHWARZ, S. Presence and dissemination of the multiresistance gene $c f r$ in Gram-positive and Gram-negative bacteria. Journal Antimicrobial Chemotherapy, v. 68, n. 8, p. 1697-706, 2013.

SILVA, L. V.; ARAÚJO, M. T.; SANTOS, K. R. N.; NUNES, A. P. F. Evaluation of the synergistic potential of vancomycin combined with other antimicrobial agents against methicillin-resistant Staphylococcus aureus and coagulase-negative Staphylococcus spp. strains. Memórias do Instituto Oswaldo Cruz, v. 106, n. 1, p. 44-50, 2011.

SINGH, A. P.; PRABHA, V.; RISHI, P. Value addition in the efficacy of conventional antibiotics by Nisin against Salmonella. PLoS One, v. 8, n. 10, e76844, 2013. 
SPEER, B. S.; SHOEMAKER, N. B.; SALYERS, A. A. Bacterial resistance to tetracycline: mechanisms, transfer and clinical significance. Clinical Microbiology Reviews, v. 5, p. 387399, 1992.

STEVENS, K. A.; SHELDON, B. W.; KLAPES, N. A.; KLAENHAMMER, T. R. Nisin treatment for inactivation of Salmonella species and other gram-negative bacteria. Applied and Environmental Microbiology, v. 57, n. 12, p. 3613-3615, 1991.

SZWEDA, P.; SCHIELMANN, M.; FRANKOWSKA, A.; KOT, B.; ZALEWSKA, M. Antibiotic resistance in Staphylococcus aureus strains isolated from cows with mastitis in eastern poland and analysis of susceptibility of resistant strains to alternative nonantibiotic agents: lysostaphin, nisin and polymyxin B. The Journal of Veterinary Medical Science, v. 76, n. 3, p. 355-362, 2014.

TAN, X.; JIANG, Y.; HUANG, Y.; HU, S. Persistence of gentamicin residues in milk after the intramammary treatment of lactating cows for mastitis. Journal of Zhejiang University SCIENCE B, v.10, n. 4, p. 280-284, 2009.

TAPONEN, S.; JANTUNEN, A.; PYÖRÄLÄ, E.; PYÖRÄLÄ, S. Efficacy of targeted five day parenteral and intramammary treatment of clinical Staphylococcus aureus mastitis caused by penicillin-susceptible or penicillin-resistant bacterial isolate. Acta Veterinaria Scandinavica, v. 44, p. 53-62, 2003.

TONG, Z.; DONG, L.; ZHOU, L.; TAO, R.; NI, L. Nisin nhibits dental caries-associated microorganism in vitro. Peptides, v. 31, p. 2003-2008, 2010.

TONG, Z.; ZHANG, Y.; LING, J.; MA, J.; HUANG, L.; ZHANG, L. An in vitro study on the effects of nisin on the antibacterial activities of 18 antibiotics against Enterococcus faecalis. PLoS One, v. 9, p. e89209, 2014.

TOZZETTI, D. S.; BATAIER, M. N.; ALMEIDA, L. R. Prevenção, controle e tratamento das mastites bovinas - Revisão de literatura. Revista Científica Eletrônica de Medicina Veterinária, 2008. n. 10.

TRABULSI, L. R.; TEIXEIRA, L. M.; BUERIS, V. Staphylococcus aureus. In: TRABULSI, L. R., et al. Microbiologia, 4. ed. São Paulo: Atheneu, 2005. p. 175-182.

TREMBLAY, Y. D. N.; LAMARCHE, D.; CHEVER, P. HAINE, D.; MESSIER, S; JACQUES, M. Characterization of the ability of coagulase-negative staphylococci isolated from the milk of Canadian farms to form biofilms. Journal of Dairy Science, v. 96, p. 234246, 2013.

TRINIDAD, P.; NICKERSON, S. C.; ALLEY, T. K. Prevalence of intramamary infection and teat canal colonization in umbred and primigravid dairy heifers. Journal of Dairy Science, v. 73, p. 107-114, 1990.

TÜRKYILMAZ, S.; TEKBIYIK, S.; ORYASIN, E.; BOZDOGAN, B. Molecular epidemiology and antimicrobial resistance mechanisms of methicillinresistant Staphylococcus aureus isolated from bovine milk. Zoonoses Public Health, v. 57, n. 3, p. 197-203, 2010. 
ULLAH, F.; MALIK, S. A. ; AHMED, J.; ULLAH, F.; MAJID, S. S.; AYAZ1, M.; HUSSAIN, S.; KHATOON, L. Investigation of the genetic basis of tetracycline resistance in Staphylococcus aureus from Pakistan. Tropical Journal of Pharmaceutical Research, v. 11, n. 6, p. 925-931, 2012.

ÜNAL, N.; ÇINAR, O. D. Detection of stapylococcal enterotoxin, methicillin-resistant and Panton-Valentine leukocidin genes in coagulase-negative Staphylococci isolated from cows and ewes with subclinical mastitis. Tropical Animal Health and Production, v. 44, p. 369$375,2012$.

VANDERHAEGHEN, W.; CERPENTIER, T.; ADRIAENSEN, C.; VICCA, J.; HERMANS, K.; BUTAYE, P. Methicillin-resistant Staphylococcus aureus (MRSA) ST398 associated with clinical and subclinical mastitis in Belgian cows. Veterinary Microbiology, v. 144, p. 166$171,2010$.

VERONESI, R.; CORREA, A.; ALTERIO, D. Single dose immunization tetanus. Promising results in human trials. Revista do Instituto Médico Tropical de São Paulo, v. 12, p. 46-54, 1970.

VIANA, G.; RINALDI, R. N. Principais fatores que influenciam o desempenho da cadeia produtiva de leite - Um estudo com os produtores de leite do município de Laranjeiras do Sul - PR. Organizações Rurais \& Agroindustriais, v. 12, n. 2, p. 263-274, 2010.

VIEIRA, D. B.; CARMONA-RIBEIRO, A. M. Synthetic bilayer fragments for solubilization of amphotericin B. Journal of Colloid and Interface Science, v. 244, p. 427-431, 2001.

VIEIRA, T. S. W. J.; RIBEIRO, M. R.; NUNES, M. P.; JUNIOR, M. M.; NETTO, D. P. Detecção de resíduos de antibióticos em amostras de leite pasteurizado do Estado do Paraná, Brasil. Ciências Agrárias, v. 33, n. 2, p. 791-796, 2012.

WORLD HEALTH ORGANIZATION, 2012. The evolving threat of antimicrobial resistance: Options for action. (http://whqlibdoc.who.int/publications/2012/97892 41503181_eng.pdf).

WU, J.; HU, S.; CAO, L. Therapeutic effect of nisin $\mathrm{Z}$ on subclinical mastitis in lactating cows. Antimicrobial Agents Chemotherapy, v. 51, p. 3131-3135, 2007.

XU, J.; TAN, X.; ZHANG, X.; XIA, X.; SUN H. The diversities of staphylococcal species, virulence and antibiotic resistance genes in the subclinical mastitis milk from a single Chinese cow herd. Microbial Pathogenesis, v. 88, p. 29-38, 2015.

YOUNT, N. Y.; YEAMAN, M. R. Peptide antimicrobials: cell wall as a bacterial target. Annals of the New York Academy of Sciences, v. 1277, p. 127-138, 2013.

ZAFALON, L. F.; POZZI, C. R.; CAMPOS, F. P.; ARCARO, J. R. P.; SARMENTO, P., MATARAZZO, S. V. Boas Práticas de ordenha. São Carlos: Embrapa Pecuária Sudeste, 2008. $50 \mathrm{p}$. 